Original article

\title{
Second-generation sulfonamide inhibitors of D-glutamic acid-adding enzyme: Activity optimisation with conformationally rigid analogues of D-glutamic acid is
}

\author{
Izidor Sosič ${ }^{a}$, Hélène Barreteau ${ }^{b}$, Mihael Simčič ${ }^{c}$, Roman Šink ${ }^{a}$, Jožko Cesar ${ }^{a}$, Anamarija Zega $^{a}$, \\ Simona Golič Grdadolnik ${ }^{\mathrm{c}, \mathrm{d}}$, Carlos Contreras-Martel ${ }^{\mathrm{e}}$, Andréa Dessen ${ }^{\mathrm{e}}$, Ana Amoroso ${ }^{\mathrm{f}}$, Bernard Joris ${ }^{\mathrm{f}}$, \\ Didier Blanot ${ }^{\mathrm{b}}$, Stanislav Gobec ${ }^{\mathrm{a}, *}$

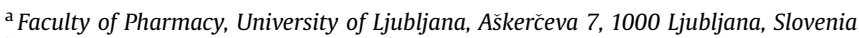 \\ ${ }^{\mathrm{b}}$ Enveloppes Bactériennes et Antibiotiques, IBBMC, UMR 8619 CNRS Univ Paris-Sud, 91405 Orsay, France \\ ${ }^{c}$ National Institute of Chemistry, Laboratory of Biomolecular Structure, Hajdrihova 19, 1000 Ljubljana, Slovenia \\ ${ }^{\mathrm{d}}$ EN-FIST Centre of Excellence, Dunajska 156, 1000 Ljubljana, Slovenia \\ ${ }^{\mathrm{e}}$ Laboratoire des Protéines Membranaires, Institut de Biologie Structurale, Jean-Pierre Ebel, CNRS, Université Joseph Fourier, 41 rue Jules Horowitz, F-38027 Grenoble, France \\ ${ }^{\mathrm{f}}$ Centre d'Ingénierie des Protéines, Institut de Chimie B6a, University of Liège, B-4000 Sart Tilman, Liège, Belgium
}

\section{A R T I C L E I N F O}

\section{Article history:}

Received 17 January 2011

Received in revised form

24 March 2011

Accepted 3 April 2011

Available online 9 April 2011

\section{Keywords:}

D-Glutamic acid-adding enzyme

Optimisation

Rigidisation

MurD inhibitors

Co-crystal structure

\begin{abstract}
A B S T R A C T
D-Glutamic acid-adding enzyme (MurD) catalyses the essential addition of D-glutamic acid to the cytoplasmic peptidoglycan precursor UDP- $N$-acetylmuramoyl-L-alanine, and as such it represents an important antibacterial drug-discovery target enzyme. Based on a series of naphthalene- $N$-sulfonyl-DGlu derivatives synthesised recently, we synthesised two series of new, optimised sulfonamide inhibitors of MurD that incorporate rigidified mimetics of D-Glu. The compounds that contained either constrained D-Glu or related rigid D-Glu mimetics showed significantly better inhibitory activities than the parent compounds, thereby confirming the advantage of molecular rigidisation in the design of MurD inhibitors. The binding modes of the best inhibitors were examined with high-resolution NMR spectroscopy and $\mathrm{X}$-ray crystallography. We have solved a new crystal structure of the complex of MurD with an inhibitor bearing a 4-aminocyclohexane-1,3-dicarboxyl moiety. These data provide an additional step towards the development of sulfonamide inhibitors with potential antibacterial activities.
\end{abstract}

(ㄷ) 2011 Elsevier Masson SAS. All rights reserved.

\section{Introduction}

The increasing resistance of Gram-positive and Gram-negative pathogens that cause severe infections in communities and in hospitals and all over the World constitutes a serious public health threat [1]. As drug-resistant infections and related morbidity are on the rise, there is an urgent need for the discovery and development of novel antibacterial agents that are directed against previously unexploited targets [2]. Peptidoglycan is an essential cell-wall polymer that is unique to prokaryotic cells, and it thus fulfils the main prerequisite for selective toxicity. It provides the rigidity,

Abbreviations: UDP, uridine 5'-diphosphate; UDP-MurNAc, UDP- $N$-acetylmuramic acid; MurC, UDP- $N$-acetylmuramate:L-alanine ligase; MurD, UDP- $N$-acetylmuramoyl-L-alanine:D-glutamate ligase; MurE, UDP- $N$-acetylmuramoyl-L-alanylD-glutamate:meso-diaminopimelate ligase; MurF, UDP- $N$-acetylmuramoyl-L-alanyl$\gamma$-D-glutamyl-meso-diaminopimelate:D-alanyl-D-alanine ligase.

is Crystallographic coordinates and structure refinement statistics have been deposited in the Protein Data Bank (PDB, accession code 2xpc).

* Corresponding author. Tel.: +386 1476 9500; fax: +3861 4258031

E-mail address: stanislav.gobec@ffa.uni-lj.si (S. Gobec). flexibility and strength required for bacterial cells to grow and divide, as well as protection against osmotic pressure [3]; it is therefore an important target in antibiotic research [4].

The intracellular assembly of the peptide stem of peptidoglycan is ensured by a series of four essential enzymes, known as the Mur ligases (MurC to MurF). These provide the consecutive additions of L-alanine (MurC), D-glutamic acid (MurD), a diamino acid, which is generally meso-diaminopimelic acid or L-lysine (MurE), and the dipeptide D-Ala-D-Ala (MurF) onto the D-lactoyl group of UDP- $N$ acetylmuramic acid (UDP-MurNAc) [4]. These ligase enzymes thus catalyse the formation of peptide bonds between UDP-precursors and amino acids or dipeptide. The reactions start by phosphorylation of the terminal carboxyl group of the nucleotide precursor, to form an acylphosphate, which is then attacked by the amine moiety of the incoming amino acid or dipeptide. The high energy tetrahedral intermediate that is produced subsequently collapses, to yield an amide or a peptide, adenosine diphosphate (ADP), and inorganic phosphate [5]. A divalent cation, as $\mathrm{Mg}^{2+}$ or $\mathrm{Mn}^{2+}$, is essential for the reaction. Of note, sequence alignments of Mur ligase orthologues and paralogues show relatively low overall 
homologies, with the exception of the residues that comprise their active sites. The ATP-binding pocket appears to be well conserved in particular, throughout this enzyme family [6-9].

Crystal structures of these Mur ligases have shown that they have similar three-dimensional structures in three domains: the $N$-terminal domain involved in the binding of the UDPprecursor, the central domain involved in the binding of ATP, and the C-terminal domain involved in the binding of the amino acid or dipeptide. While the topologies of the central and C-terminal domains are similar among the Mur ligases, those of the $\mathrm{N}$-terminal domains show differences, with MurC and MurD more closely related to each other than to MurE and MurF. These differences are related to the lengths of the UDP-precursor substrates [10]. Furthermore, the open and closed X-ray structures of free and complexed MurD [11-13] and MurF [14,15] show that the Cterminal domain undergoes substantial conformational changes upon substrate or inhibitor binding [16].

The main focus of our research has been MurD, the second enzyme in the series of Mur ligases. It catalyses the formation of the peptide bond between UDP- $N$-acetylmuramoyl-L-alanine (UMA) and D-Glu. The importance of this enzyme as a potential drug target has resulted in several attempts to design inhibitors of MurD over the last 15 years. For instance, the effects of various analogues of D-Glu on MurD from Escherichia coli have been studied, and some alternative substrates were described [17]. Many phosphonic acids and phosphinates (e.g., Fig. 1, compound 1) have been developed as substrate analogues and tetrahedral transition-state analogue inhibitors of MurD, respectively [18-23]. Several inhibitors were also identified from a library of $\mathrm{N}$-acyl-D-Glu derivatives; those containing an indole moiety appeared to be of special interest [24]. A series of compounds with an $\mathrm{N}$-acylhydrazone scaffold was synthesised and compound 2 (Fig. 1) was identified as the most potent inhibitor [25]. Using de-novo structure-based molecular design, a series of macrocyclic inhibitors 3 (Fig. 1) was developed, which showed $\mathrm{IC}_{50}$ values in the low micromolar range [26]. Peptide inhibitors of MurD from Pseudomonas aeruginosa were obtained by screening of phage display libraries using competitive biopanning approaches, with the best $\mathrm{IC}_{50}$ value obtained of $4 \mu \mathrm{M}$ [27]. Pyrazole derivatives [28] and pulvinones [29] have been reported to be potential inhibitors of MurB-MurD and MurA-MurD, respectively. An example of the computational methods that have provided four novel MurD inhibitors (e.g., Fig. 1, compound 4) was the approach of virtual screening and subsequent in-vitro biochemical evaluation of the best-ranked compounds [30]. Using a new high-throughput fluorimetric assay, a focused library of around 1000 compounds was also screened for inhibition of MurD, and a novel inhibitor belonging to a new structural class was discovered (i.e., Fig. 1, compound 5) [31].

Recently, the high-resolution co-crystal structures of MurD with $\mathrm{N}$-sulfonyl-L-Glu $(\mathbf{9})\left(\mathrm{IC}_{50}=710 \mu \mathrm{M}\right)$ and $\mathrm{N}$-sulfonyl-D-Glu (10) $\left(\mathrm{IC}_{50}=280 \mu \mathrm{M}\right)$ (Fig. 1) were reported. The binding modes of these inhibitors were also characterised according to their enzyme kinetics. Here, the configuration of the glutamic acid moiety of this type of inhibitor did not need to be D, since the $\mathrm{N}$-sulfonyl-L-Glu analogue $\mathbf{9}$ can bind to the D-Glu-binding site in a similar manner to the D-Glu counterpart 10, and it was only 4-fold less potent [32]. Interestingly, the same trend was seen with compounds $\mathbf{7}$ and $\mathbf{8}$, which bear both the glutamic acid and 5-benzylidenerhodanine moieties (Fig. 1) [33]. A series of naphthalene- $N$-sulfonyl-D-Glu derivatives related to $\mathbf{1 0}$ was designed and synthesised in an attempt to obtain improved inhibitors (Fig. 1, compound 11) and four additional co-crystal structures were reported [34]. Furthermore, these compounds were also the subject of extensive, highresolution nuclear magnetic resonance (NMR) and molecular dynamics studies, which shed additional light on the static models obtained from the co-crystal structures [35]. Such information from experimentally determined positions and conformations of inhibitors in the MurD active site provides excellent insight into the structure-activity relationships, and offers a solid foundation for further development and optimisation of inhibitors from this structural class.

In the present study, we describe our approach to the design of a second generation of sulfonamide inhibitors of MurD that are related to compounds $\mathbf{1 0}$ and $\mathbf{1 1}$ (Fig. 1). We optimised these inhibitors through the rigidisation of their D-glutamic acid moiety. As rigidisation represents an important aspect in medicinal chemistry optimisation processes, most probably due to minimising the entropic penalty upon binding of ligands in the active site of

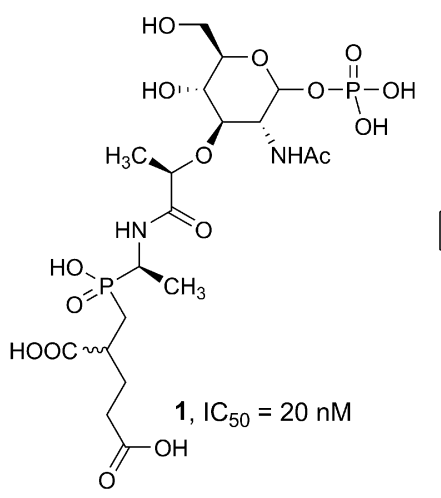

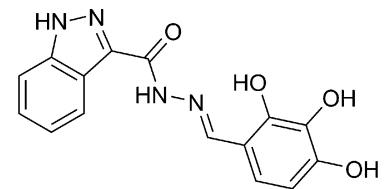

2, $\mathrm{IC}_{50}=324 \mu \mathrm{M}$<smiles>CCCCCCCCCCCCCC[C@@H](CC(=O)[C@H](C)NC(=O)[C@H](CO)NC(C)=O)C(=O)O</smiles>

3, $I_{50}=0.7 \mu \mathrm{M}$<smiles>O=C(O)c1c(Br)c(Br)c(Br)c(Br)c1C1c2ccc(O)cc2Oc2cc(O)ccc21</smiles>

4, $I C_{50}=10 \mu \mathrm{M}$<smiles>Cc1ccc(C(=O)O)cc1NC(=O)CSc1nnc(N)s1</smiles>

5, $\mathrm{IC}_{50}=105 \mu \mathrm{M}$<smiles>O=C(O)CC[C@H](NC(=O)c1ccc(CNc2cccc(/C=C3\SC(=S)NC3=O)c2)cc1)C(=O)O</smiles>

7, $I C_{50}=206 \mu \mathrm{M}$ (L-isomer)

8, $I_{50}=174 \mu \mathrm{M}$ (D-isomer)<smiles>N#Cc1ccc(COc2ccc3cc(S(=O)(=O)N[C@@H](CCC(=O)O)C(=O)O)ccc3c2)c(F)c1</smiles>

Fig. 1. Structural formulae of some MurD ligase inhibitors. 
the enzyme [36], we postulated that this approach would contribute to potentiation of the binding affinities and improved inhibitory activities of these synthesised compounds. In addition, we present the crystal structure of a rigidified inhibitor in complex with MurD, as well as high-resolution NMR data additionally confirming the binding of these novel inhibitors to the active site of MurD.

\section{Chemistry}

To find new MurD inhibitors, compounds 10 and 11 (Fig. 1) were used as the starting points for further derivatisation and optimisation. We wanted to replace the D-glutamic acid moiety of these two compounds with different rigid fragments that would mimic D-glutamic acid. The conformationally rigid D-Glu mimetics were comprised of either an aromatic or an aliphatic ring, with various polar substituents $\left(\mathrm{OH}, \mathrm{COOH}, \mathrm{CH}_{2} \mathrm{COOH}\right)$ at different positions of the ring. The majority of the aromatic and cyclic aliphatic amines used (Table 1) were commercially available (compounds 12a-c and 12e-h), except diethyl 4-aminocyclohexane-1,3-dicarboxylate (12d) and dimethyl 4-aminoisophthalate (12i). As we wanted to cover the substitution patterns on the aliphatic and aromatic rings as much as possible, we decided to synthesise these two constrained D-Glu mimetics. The syntheses of these two amines are shown in Schemes 1 and 2.

The preparation of diethyl 4-oxocyclohexane-1,3-dicarboxylate (14) was achieved by the Dieckmann cyclisation of triethyl pentane1,3,5-tricarboxylate (13) using sodium as the base (Scheme 1). The desired cyclic aliphatic amine 12d was then synthesised using two different approaches. The first consisted of the formation of the oxime derivative $\mathbf{1 5}$ that was promptly (due to instability of the compound) reduced to 12d using Raney-Ni as a catalyst [37]. Since the overall yield of this synthesis (16\%) was not satisfactory, we also prepared the target compound $\mathbf{1 2 d}$ by reductive amination of $\mathbf{1 4}$, using benzylamine and sodium triacetoxyborohydride as the reducing agent [38]. Despite the steric hindrance of ketone 14, the reaction proceeded smoothly and with good yield (72\%). The final deprotection of the amino group was achieved by catalytic hydrogenolysis, to yield 12d. For further reactions, the 12d obtained with this second synthetic procedure was used.

The second synthesis of the constrained Glu derivative 12d proceeded with unexpected stereoselectivity. Even though two chiral centres were formed during the cyclisation step to obtain the ketone 14, the reaction proceeded diastereoselectively, and a single pair of enantiomers was isolated, as confirmed by HPLC (see Supplementary data). Moreover, reductive amination of $\mathbf{1 4}$ also

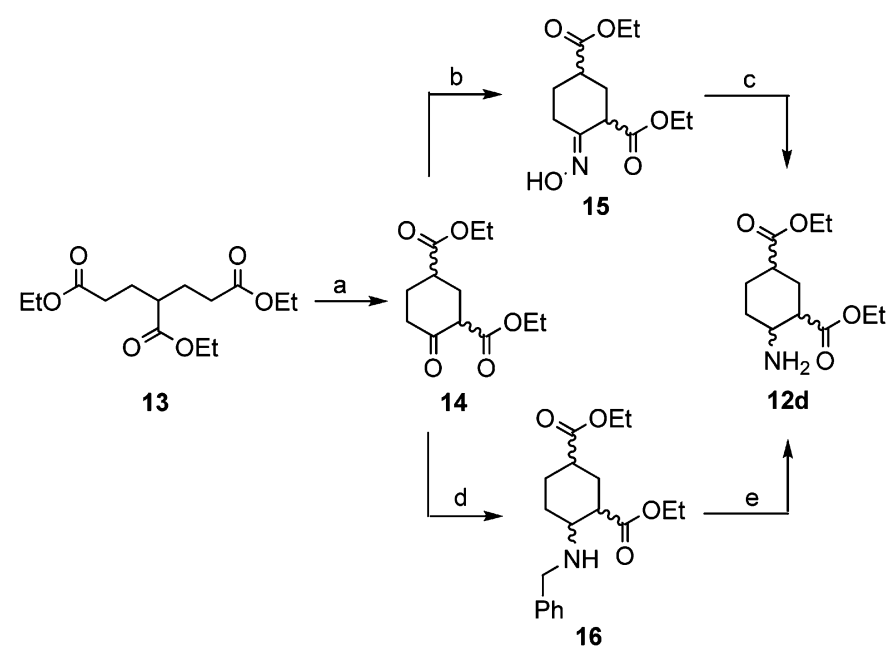

Scheme 1. Reagents and conditions: (a) Na, EtOH, toluene, $80{ }^{\circ} \mathrm{C}$; (b) $\mathrm{NH}_{2} \mathrm{OH} \times \mathrm{HCl}, \mathrm{Na}_{2} \mathrm{CO}_{3}, \mathrm{H}_{2} \mathrm{O} / \mathrm{EtOH}$; (c) $\mathrm{H}_{2}$, Raney-Ni, $i$-PrOH; (d) Benzylamine, $\mathrm{Na}(\mathrm{OAc})_{3} \mathrm{BH}, 1$,2-dichloroethane; (e) $\mathrm{H}_{2}$, Pd/C, EtOH, 20 bar.

took place stereoselectively, and compound 16, which has three chiral carbons (and can potentially exist in eight stereoisomeric forms), was isolated after purification as a single enantiomeric pair. For both compounds (14 and 16), HPLC analysis on a high resolution (achiral) C18 column with high efficiency (plate number 300,000) gave a single symmetric peak, indicating that there were no diastereoisomers. With chiral columns, two separate peaks with a $1: 1$ area ratio were seen, clearly demonstrating the formation of an enantiomeric pair (see HPLC spectra in the Supplementary data).

The synthesis of aromatic amine 12i was also performed using two different approaches. The initial step in the first reaction pathway was microwave-assisted copper-catalysed $\mathrm{C}-\mathrm{N}$ bond formation using 4-bromisophthalic acid and benzylamine [39]. The carboxyl groups of the resulting compound $\mathbf{1 8}$ were subsequently protected as methyl esters using thionyl chloride and $\mathrm{MeOH}$. The benzyl group of $\mathbf{1 9}$ was then easily removed with catalytic hydrogenation, to obtain the aromatic amine 12i. The overall yield of this approach was very low (13\%), which was mostly due to the poor conversion of $\mathbf{1 7}$ to $\mathbf{1 8}$ in the first reaction step. The title 2,4disubstituted aniline $\mathbf{1 2 i}$ was therefore synthesised using a different approach, starting from commercially available methyl 2-amino-5-furoate (20) and methyl acrylate, following a literature procedure [40]. After Diels-Alder reaction in the first step the aminosubstituted 7-oxabicyclo[2.2.1]heptene $\mathbf{2 1}$ was spontaneously

Table 1

Structures of C-protected conformationally rigid D-Glu mimetics.

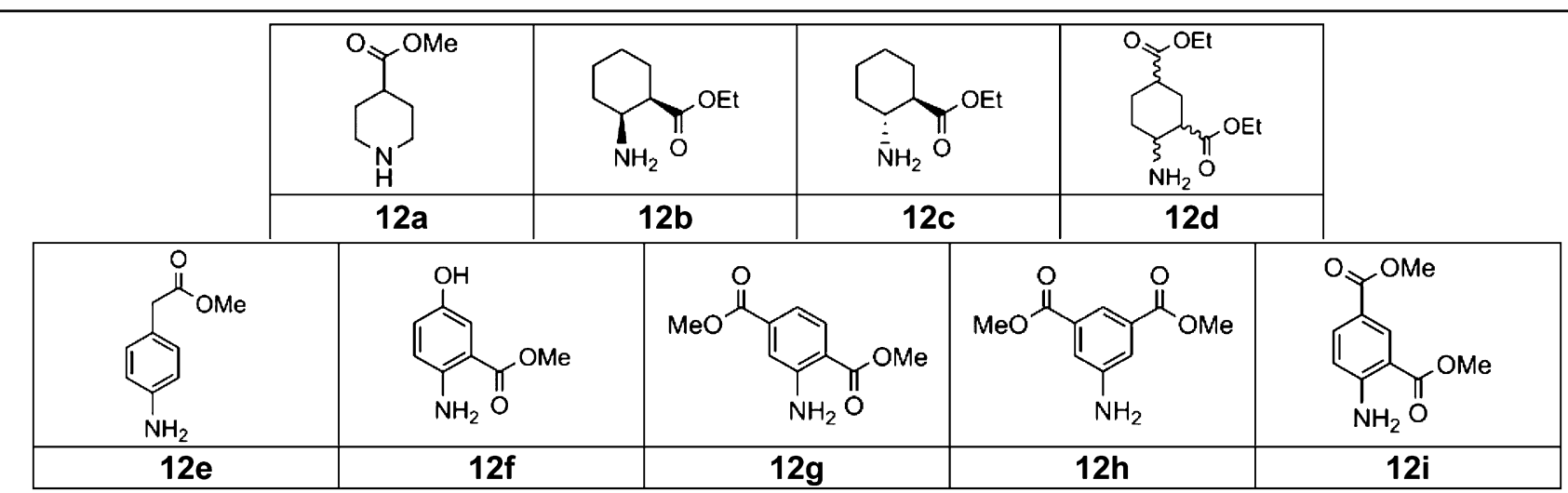


<smiles>N[14CH2]c1ccccc1</smiles>

17<smiles>O=C(O)c1ccc(Nc2ccccc2)c(C(=O)O)c1</smiles>

18<smiles>COC(=O)c1ccc(NCc2ccccc2)c(C(=O)OC)c1</smiles>

19<smiles>CCCCCCOC</smiles><smiles>COC(=O)c1ccc(N)c(C(=O)OC)c1</smiles><smiles>C=CC(=O)OC</smiles>
20<smiles>COC(=O)C1=C(N)C=CC(O)(C(=O)OC)C1</smiles>

22

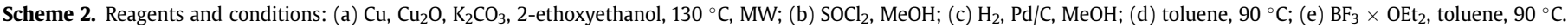

converted to substituted aniline $\mathbf{2 2}$. The conversion was quantitative and the product $\mathbf{2 2}$ was used immediately for the next step, a reaction with $\mathrm{BF}_{3} \times \mathrm{Et}_{2} \mathrm{O}$ in toluene at $90{ }^{\circ} \mathrm{C}$ which resulted in smooth dehydration and gave the 2,4-disubstituted aniline $\mathbf{1 2} \mathbf{i}$ in very high yield (88\%).

The rigid sulfonamide inhibitors were synthesised as shown in Scheme 3. The 6-substituted naphthalene-2-sulfonyl chlorides (27 and 28) were prepared from sodium 6-hydroxynaphthalene sulfonic acid (23), according to a procedure in the literature [34]. Aromatic and cyclic aliphatic amines with variously protected carboxyl groups at different positions (Table $1, \mathbf{1 2 a}-\mathbf{i}$ ) were then successfully reacted with these two sulfonyl chlorides, which yielded the sulfonamides $\mathbf{2 9} \mathbf{a}-\mathbf{i}$ and $\mathbf{3 0 a}-\mathbf{i}$. These esters were subsequently deprotected with alkaline hydrolysis, to the target compounds $31 \mathbf{a}-\mathbf{i}$ and $\mathbf{3 2 a}-\mathbf{i}$ (Table 2). For deprotection of the carboxyl groups of compounds $29 \mathbf{a}-\mathbf{i}$ and $30 \mathbf{a}-\mathbf{i}$, alkaline hydrolysis was applied.

\section{Results and discussion}

\subsection{MurD inhibitory and antibacterial activities}

The target compounds were tested for their inhibitory activities on MurD from E. coli. The results were determined as residual activities (RAs) of the enzyme in the presence of $500 \mu \mathrm{M}$ or $1 \mathrm{mM}$ of each compound, and also as $\mathrm{IC}_{50}$ and $\mathrm{K}_{\mathrm{i}}$ values for the most active compounds (Table 2).

The first series of synthesised compounds consisted of 6-butoxynaphthalene-2-sulfonamide derivatives (31a-31i). The compounds that had only one carboxyl group, 31a-c and 31e, were not active against MurD. These data were not surprising as it is known from previously published inhibitors that both of the carboxyl groups of D-Glu form important interactions with the active site of MurD [23,34]. We thus confirmed that amines with only one carboxyl group are poor mimetics of glutamic acid. As expected, slightly better inhibition was seen with compounds $\mathbf{3 1 f}$ 31i, which have two polar groups at various positions on the aromatic ring. The most interesting data was from the comparison of the inhibitory potencies of compounds $\mathbf{3 1 f}$ (RA at $500 \mu \mathrm{M}, 76 \%$ ) and 31i (RA at $1 \mathrm{mM}, 8 \%$; IC $50=127 \mu \mathrm{M}$ ). The importance of the carboxyl group at the para position with respect to the sulfonamide moiety was evident, in comparison with the hydroxyl group. We can see that substituents that can form additional hydrogen bonds or charge-based interactions contribute greatly to the inhibition of MurD.

The best inhibitors were obtained with the second series of compounds, the [6-(4-cyano-2-fluorobenzyloxy)-naphthalene-2sulfonamide derivatives 32a-32i]. Compounds 32a and 32c were practically inactive. With a comparison of the residual activities of compounds 32b (RA, 45\%) and 32c (RA, 88\%), it can be noted that

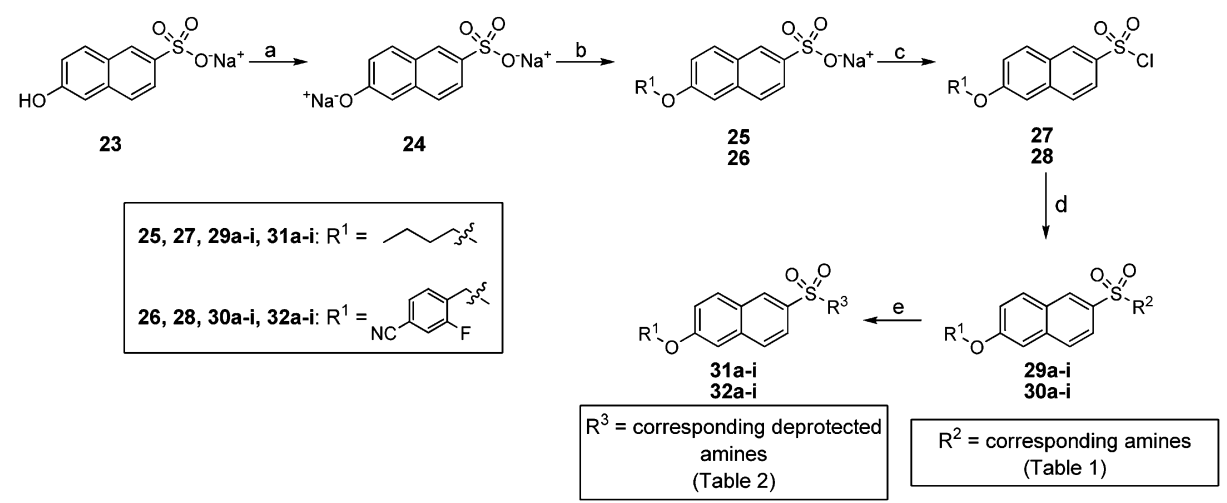

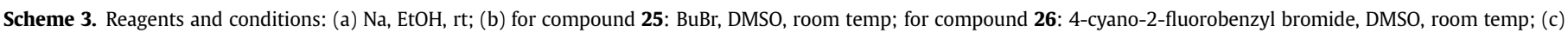

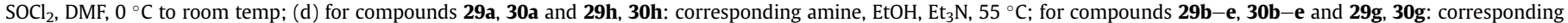

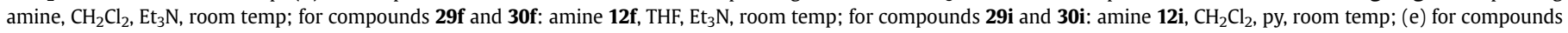
31a-i: $1 \mathrm{M} \mathrm{NaOH}$, dioxane, room temp; for compounds 32a-i: $2 \mathrm{M} \mathrm{LiOH}$, dioxane, room temp. 
Table 2

MurD inhibitory potencies of compounds as conformationally rigid analogues of D-glutamic acid. ${ }^{a}$

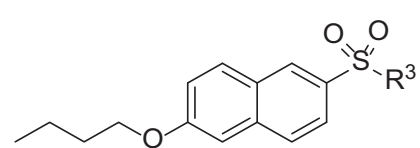

$\mathbf{R}^{3}$<smiles>CNC(CCC(=O)O)C(=O)O</smiles>

$\mathrm{IC}_{50}=280 \mu \mathrm{M}$

$\mathrm{K}_{\mathrm{i}}=192 \mu \mathrm{M}^{\mathrm{d}}$

97<smiles>CN[C@H]1C[14CH2]CC[C@H](C(=O)O)[C@H]1NC</smiles>

$93^{c}$<smiles>CN[C@H]1CCCC[C@H]1C(=O)O</smiles>

31c<smiles></smiles>

31d<smiles>CNc1ccc(CC(=O)O)cc1</smiles>

31e<smiles>CNc1ccc(O)cc1C(=O)O</smiles><smiles>CC(F)(F)Nc1ccc(C(=O)O)cc1C(=O)O</smiles>

$31 \mathrm{~g}$
RA (\%) of MurD ${ }^{b}$<smiles>[R]S(=O)(=O)c1ccc2cc(OCc3ccc(C#N)cc3F)ccc2c1</smiles>

$\mathbf{R}^{3}$

RA (\%) of MurD ${ }^{b}$<smiles>CNC(CCC(=O)O)C(=O)O</smiles>

$\mathrm{IC}_{50}=85 \mu \mathrm{M}$

$\mathrm{K}_{\mathrm{i}}=58 \mu \mathrm{M}^{\mathrm{d}}$<smiles>CN1CCC(C(=O)O)CC1</smiles>

94<smiles>CN[C@H]1CCCC[C@@H]1C(=O)O</smiles>

$45^{c}$<smiles>CN[C@H]1CCCC[C@@H]1C(=O)O</smiles>

$88^{c}$

32c<smiles></smiles>

$14^{\mathrm{c}}$

$\mathrm{IC}_{50}=182 \mu \mathrm{M}$ $\mathrm{K}_{\mathrm{i}}=125 \mu \mathrm{M}^{\mathrm{d}}$

32d<smiles>CNc1ccc(CC(=O)O)cc1</smiles>

64

$$
\begin{aligned}
& 3 \\
& \mathrm{IC}_{50}=46 \mu \mathrm{M} \\
& \mathrm{K}_{\mathrm{i}}=32 \mu \mathrm{M}^{\mathrm{d}} \\
& \\
& 2^{\mathrm{c}} \\
& \mathrm{IC}_{50}=38 \mu \mathrm{M} \\
& \mathrm{K}_{\mathrm{i}}=26 \mu \mathrm{M}^{\mathrm{d}}
\end{aligned}
$$

$32 f$<smiles>CNc1cc(C(=O)O)ccc1C(=O)O</smiles>

(continued on next page) 
<smiles>CNc1cc(C(=O)O)cc(C(=O)O)c1</smiles>

$31 \mathrm{~h}$<smiles>CC(F)(F)Nc1ccc(C(=O)O)cc1C(=O)O</smiles>

$31 i$
70<smiles>CNc1cc(C(=O)O)cc(C(=O)O)c1</smiles>

32h<smiles>CNc1ccc(C(=O)O)cc1C(=O)O</smiles>

$32 \mathrm{i}$

\footnotetext{
a The data represent the mean values of two independent experiments. Standard deviations were within $\pm 10 \%$ of these mean values.

b Except where noted otherwise, RA was determined at $500 \mu \mathrm{M}$ of each compound.

c RA was determined at $1 \mathrm{mM}$ of each compound.

${ }^{\mathrm{d}} \mathrm{K}_{\mathrm{i}}$ values were calculated using the Cheng-Prusoff equation.
}

the stereochemistry on the saturated ring does have a role in mimicking the position of the $\alpha$-carboxyl group of D-glutamic acid. The $(1 R, 2 S)$-configuration on the cyclohexyl ring appeared to present a preferable spatial orientation for the carboxyl and sulfonamide groups. Very promising MurD inhibition was obtained with compound 32d, which showed an IC 50 of $182 \mu \mathrm{M}$. This makes compound 32d particularly interesting for further investigations, as it is a mixture of two enantiomers. As discussed above for intermediates 14 and 16, HPLC chromatograms of esters 29d and 30d, and those of the corresponding acids $\mathbf{3 1 d}$ and 32d, showed that these compounds were isolated as single enantiomeric pairs with 1:1 ratios of their two enantiomers (see Supplementary data). As has been seen previously, the poor inhibitory activity of compound 31d in comparison with 32d might have arisen because the $p$-cyano-2-fluorobenzyloxy group at position 6 of the naphthalene ring contributes to a better affinity, as the cyano group forms additional hydrogen bonds with the MurD active site [34].

Valuable information can be obtained from the inhibition assay results of compounds $\mathbf{3 2 f}-\mathbf{i}$. All of these compounds were better inhibitors than compound 11, which was our starting point. While compounds $\mathbf{3 2 f}-\mathbf{h}$ had almost identical inhibitory activities $\left(\mathrm{IC}_{50}\right.$ values between 38 and $50 \mu \mathrm{M}$ ), compound 32i exhibited 5-fold better inhibition $\left(\mathrm{IC}_{50}=8.4 \mu \mathrm{M}\right)$. Again, to obtain a more potent inhibitor, it was significantly better with the carboxyl group positioned para with respect to the sulfonamide group rather than the hydroxyl group.

To sum up, from the 6-butoxynaphthalene-2-sulfonamide series of compounds (31a-31i), 31i was the most potent, with an $\mathrm{IC}_{50}$ of $127 \mu \mathrm{M}$. When comparing its activity with compound $\mathbf{1 0}$ (Fig. 1), it can be noted that the rigidisation had here led to a more potent inhibitor. Even better results were obtained with the second series of compounds, which had the p-cyano-2-fluorobenzyloxy side chain (32a-32i). Compounds $32 \mathbf{f}-\mathbf{i}\left(\mathrm{IC}_{50}\right.$ values between 8.4 and $50 \mu \mathrm{M}$ ) were all more potent inhibitors than the parent D-Glu derivative $\mathbf{1 1}$ (Fig. 1). We showed that the best D-Glu constrained mimetic was the amine $\mathbf{1 2} \mathbf{i}$, as it appears that the 4-amino-1,3dicarboxyl substitution pattern on the phenyl ring was the best for mimicking the polar groups of glutamic acid. Compound $\mathbf{3 2 i}$ $\left(\mathrm{IC}_{50}=8.4 \mu \mathrm{M}\right)$ contained this moiety and exhibited a more than 10 -fold increase in inhibitory activity when compared with compound 11. From the results of the inhibition assays (Table 2), we conclude that incorporation of a rigid surrogate into the D-glutamic acid moiety can potentiate the binding affinity, and thus contribute to better inhibitory activities of these synthesised molecules. This was recently also confirmed in a series of benzene-1,3dicarboxylate-containing compounds, which were discovered by virtual high-throughput screening for MurD and MurE [41].

All of the compounds were tested for their in-vitro antibacterial activity against several different Gram-negative and Gram-positive bacterial strains. The data are given in Table S2 of the Supplementary data. These compounds were unfortunately found to be weak inhibitors of bacterial growth. This might be ascribed to their poor penetration into the bacterial cytoplasm. Nevertheless, some compounds showed modest antibacterial activities; e.g., 31b, 31c and 31d against Listeria innocua, Listeria monocytogenes, Bacillus subtilis and Enterococcus hirae, with minimal inhibitory concentrations (MICs) of $32 \mu \mathrm{g} / \mathrm{mL}$ or $64 \mu \mathrm{g} / \mathrm{mL}$. Interestingly, compound 31d also moderately prevented the growth of one strain (PL1) of inducible methicillin-resistant Staphylococcus aureus. However, as these compounds were very poor inhibitors, if at all, of MurD, the antibacterial activities observed were probably due to their interactions with another bacterial target.

\section{2. $N M R$}

With MurD selectively labelled with ${ }^{13} \mathrm{C}$ at the methyl groups of Ile, Val and Leu [42], the monitoring of its ${ }^{1} \mathrm{H} /{ }^{13} \mathrm{C}$ chemical shift changes upon binding of selected new ligands (31d, 31h, 32f-i) was performed, to support the specific action of these inhibitors and to determine the location of the ligands in the MurD binding site. We demonstrated that these new inhibitors bind to the active site in a similar manner to that previously established for compounds $\mathbf{1 0}$ and 11, using X-ray diffraction [32,34] and highresolution NMR [35]. The same methyl resonances of MurD were affected upon binding of new ligands as observed for compounds 10 and 11. Typically pronounced effects on chemical shifts of Leu416 methyl groups were observed upon binding of inhibitors (Fig. 2). This is a consequence of ring-current effects of the naphthalene ring, which is in close spatial proximity to Leu416, and it indicates the similar location of the naphthalene ring in the binding site as for the naphthalene- $N$-sulfonamide-D-Glu derivatives. The signals of these Leu416 methyl groups are the only ones that are affected upon binding of D-glutamic acid, and they are indicative of the location of the ligands in the D-Glu-binding pocket. The occupancy of the uracil-binding pocket with the C6-substituent was established through the pronounced effects on the chemical shifts of the 


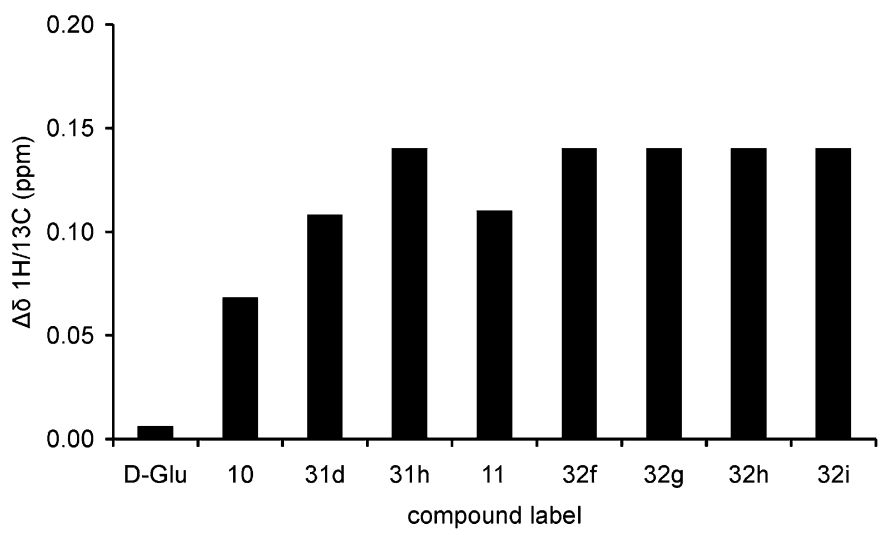

Fig. 2. The combined chemical shift perturbations of the Leu416 methyl group calculated from the ${ }^{1} \mathrm{H}$ and ${ }^{13} \mathrm{C}$ chemical shifts in the absence and presence of the indicated compounds at a 5:1 ligand:MurD ratio. For compounds 31d, 31h, 32f, 32g, 32h and 32i, the minimum possible chemical shift perturbation is presented, as the signals moved to the overlapped region of the spectra at a 5:1 ligand:MurD ratio. The chemical shift perturbations of the other Leu416 methyl group are not presented, as the signals moved to the overlapped region of the spectra after the first addition of the naphthalene- $\mathrm{N}$-sulfonamide derivatives.

Leu57 and Ile74 methyl groups. In general the 6-(4-cyano-2-fluorobenzyloxy)-naphthalene derivatives had greater effects on these chemical shifts than the 6-butoxynaphthalene derivatives. A similar difference was seen upon the binding of compounds 10 and 11, which can be attributed to the ring-current effects of the arylalkyloxy substituent (Figs. 3 and 4). The side chains of Leu57 and Ile74 constitute the hydrophobic environment of the uracil-binding pocket and are in close spatial proximity to the C6-substituent of the naphthalene- $N$-sulfonamide-D-Glu derivatives [32,34,35].

\subsection{Crystal structure of MurD in complex with compound 32d}

To additionally confirm the atomic detail of the binding mode of these inhibitors within the MurD active site, the crystal structure of the complex between MurD and inhibitor 32d was solved to high resolution (Fig. 5). Compound 32d was obtained as a mixture of two enantiomers (see above), and the mixture was soaked in crystals of MurD (see Experimental Section). The data was collected at the European Synchrotron Radiation Facility (Grenoble, France), and the structure of the complex was solved by molecular replacement using the structure of the apo form of MurD as the search model. Of note, only one stereoisomer was seen in the co-crystal structure.

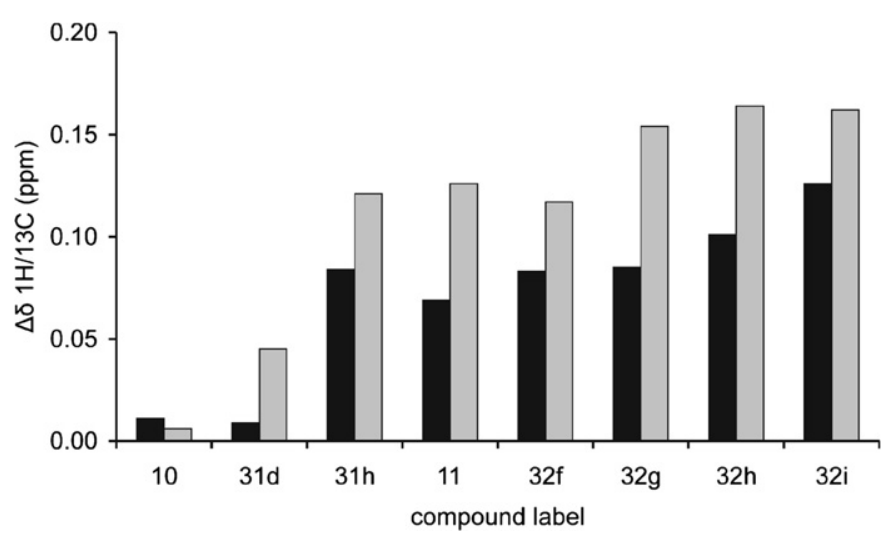

Fig. 3. The combined chemical shift perturbations of the Leu57 methyl groups calculated from the ${ }^{1} \mathrm{H}$ and ${ }^{13} \mathrm{C}$ chemical shifts in the absence and presence of the indicated compounds at a 10:1 ligand:MurD ratio.

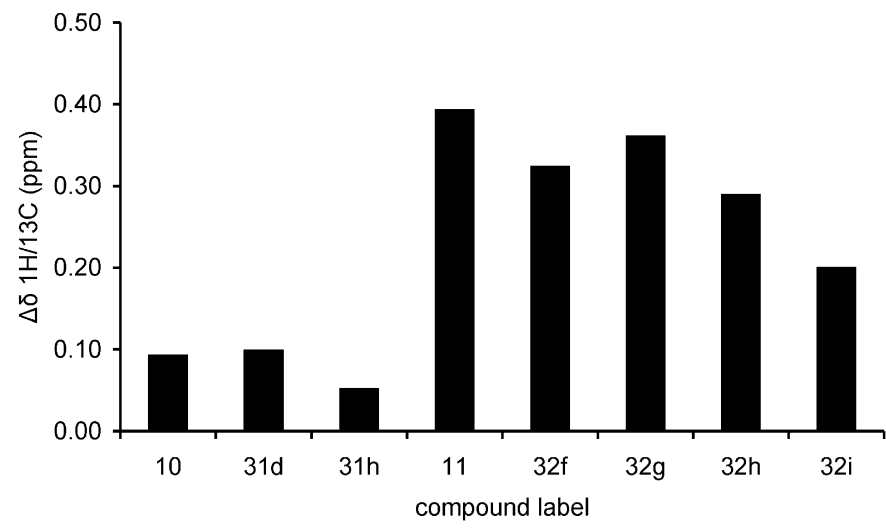

Fig. 4. The combined chemical shift perturbations of the Ile74 $\delta 1$ methyl group calculated from the ${ }^{1} \mathrm{H}$ and ${ }^{13} \mathrm{C}$ chemical shifts in the absence and presence of the indicated compounds at a 10:1 ligand:MurD ratio.

The absolute configuration of the crystallised compound was $(1 R, 3 R, 4 S)$. This is in agreement with the inhibition assay results that were obtained with compounds $\mathbf{3 2 b}$ and $\mathbf{3 2 c}$, as compound 32b, which has the $(1 R, 2 S)$-absolute configuration, showed better inhibitory activity (N.B., compliance with the IUPAC nomenclature rules alters the numbering priorities when an additional carboxyl group is on the ring). The carboxyl groups at positions 1 and 3 of the rigid cyclohexyl mimetic of D-glutamic acid occupy exactly the same position as the carboxyl groups of D-glutamic acid of previously described inhibitors [32,34] and of the product UDP-MurNAcL-Ala-D-Glu [11]. The carboxyl group at position 3 of the cyclohexyl ring of the inhibitor forms a charge-based interaction with $N^{\xi}$ of Lys348, and is additionally hydrogen-bonded with a conserved water molecule, W38, which is further hydrogen-bonded to $O^{\gamma}$ of Thr321 and the carboxyl group of Asp182. The carboxyl group at position 1 of the cyclohexyl ring is held in place by hydrogen bonds with $O^{\gamma}$ of Ser415 and the backbone nitrogen of Phe422. The sulfonic group also contributes to the recognition in the active site by making hydrogen bonds with His183 and water molecules W183, W242 and W415; W183 and W242 further interact with the side-chain carboxyl of Asp346. The naphthalene ring of the

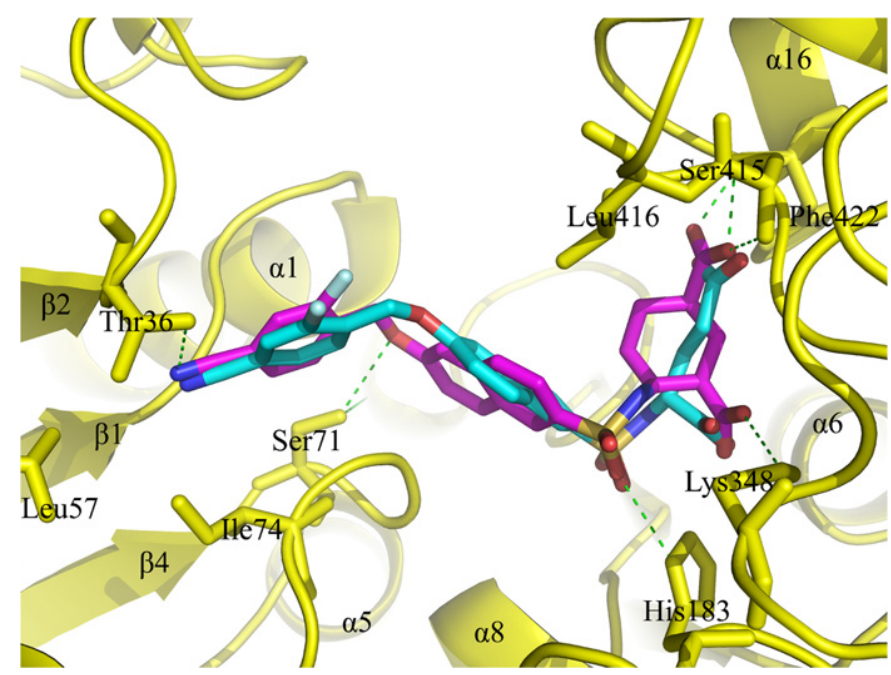

Fig. 5. Binding mode of compound 32d (magenta) in the active site of E. coli MurD (interactions with conserved water molecules are not shown). The superposition with compound 11 (cyan) is also shown. (For interpretation of the references to colour in this figure legend, the reader is referred to the web version of this article.) 
inhibitor is making hydrophobic interactions with Leu416, Phe161 and $\mathrm{C}^{\alpha}$ of Gly73. The functional group at position 6 of the naphthalene ring extends into the uracil-binding pocket. The oxygen at position 6 interacted with $O^{\gamma}$ of Ser71, and the cyano group at position 4 of the phenyl ring is hydrogen-bonded to $O^{\beta}$ of Thr36. The phenyl ring makes interplane stacking interactions with Asp35 and Arg37.

\section{Conclusions}

We have synthesised two series of new, optimised sulfonamide inhibitors of MurD that incorporate rigidified mimetics of D-Glu. These compounds showed better inhibitory activities than the starting compounds, thereby confirming the advantage of such constrained glutamic acid analogues. Additionally, we solved a new crystal structure of the inhibitor with a 4-aminocyclohexane-1,3dicarboxyl moiety in complex with MurD. We have described several possible rigid surrogates of D-Glu that can be used for further optimisation of inhibitors of MurD. These data provide another step forwards towards the development of sulfonamide inhibitors with antibacterial activities.

\section{Experimental section}

\subsection{Inhibition assay}

The compounds were tested for inhibition of addition of $\mathrm{D}-\left[{ }^{14} \mathrm{C}\right]-$ Glu to UMA catalysed by MurD from E. coli [43] using a mixture (final volume, $50 \mu \mathrm{L}$ ) containing $0.1 \mathrm{M}$ Tris- $\mathrm{HCl}, \mathrm{pH} 8.6,5 \mathrm{mM}$ $\mathrm{MgCl}_{2}, 25 \mu \mathrm{M}$ UDP-MurNAc-L-Ala, $25 \mu \mathrm{M}$ D- $\left[{ }^{14} \mathrm{C}\right]-$ Glu $(50,000 \mathrm{cpm})$, $5 \%(\mathrm{v} / \mathrm{v})$ DMSO, $30 \mu \mathrm{M}$ Tween 20, purified MurD (diluted in $20 \mathrm{mM}$ potassium phosphate, $\mathrm{pH} 7.0,1 \mathrm{mM}$ dithiothreitol, $1 \mathrm{mg} / \mathrm{mL}$ BSA), and $500 \mu \mathrm{M}$ or $1 \mathrm{mM}$ of each test compound (at these concentrations, the compounds were soluble in the assay mixture containing DMSO). The enzyme concentration in the final mixture was $0.5 \mathrm{nM}$. The mixture was incubated at $37{ }^{\circ} \mathrm{C}$ for $30 \mathrm{~min}$, and the reaction was stopped by adding $10 \mu \mathrm{L}$ glacial acetic acid. The resulting mixture was lyophilised and taken up in water (ca. $10 \mu \mathrm{l})$. The radioactive substrate and product were separated by TLC on LK6D silica gel plates (Whatman), which were developed in 1-propanol/ ammonium hydroxide/water, 6/3/1 (v/v), and quantified with a radioactivity scanner (model Multi-Tracemaster LB285, BertholdFrance, Thoiry, France). Residual activity was calculated with respect to a similar assay without the inhibitors. The data are expressed as means of duplicate determinations, and the standard deviations were within $10 \%$ of the given values. All enzyme assays were performed at the initial velocity conditions (linearity ensured until $30 \mathrm{~min}$ ). The $\mathrm{IC}_{50}$ values were calculated from the fitted regression equation using the logit-log plot. $\mathrm{K}_{\mathrm{i}}$ values for the most potent compounds were calculated using the Cheng-Prusoff equation since it is known from X-ray and NMR experiments that inhibitors are competitive towards $\mathrm{D}-\mathrm{Glu}\left(\mathrm{K}_{\mathrm{m}}\right.$ value for $\mathrm{D}$-Glu: $55 \mu \mathrm{M})$.

\subsection{Antimicrobial activity evaluation}

Tests for antimicrobial activities were carried out using microtitration plates, in $200 \mu$ l (final volume) of Müeller-Hinton broth (MHB), following the procedures recommended by the European Committee for Antimicrobial Susceptibility Testing [44] and the Clinical Laboratory Standards Institute [45]. The compounds were dissolved in 100\% DMF and then diluted 50-fold in MHB, just before use. Inoculums were prepared for each strain, with resuspended isolated colonies from $18 \mathrm{~h}$ cultured plates. Equivalents of 0.5 MacFarland turbidity standard (approximately $1.10^{8} \mathrm{CFU} / \mathrm{ml}$ ) were prepared in saline solution $(0.085 \% \mathrm{NaCl})$ and then diluted 200 -fold in $\mathrm{MBH}$ (initial population). The MICs were determined as the lowest dilutions of the products showing no visual turbidity. Bacterial strains (Supplementary data, Table S2) were purchased from the BCCM/LMG Laboratorium voor Microbiologie, Universiteit Gent (UGent), Belgium.

\subsection{NMR spectroscopy}

The ${ }^{1} \mathrm{H} /{ }^{13} \mathrm{C}$ HSQC [46] spectra were recorded at $25^{\circ} \mathrm{C}$ on a Varian DirectDrive $800 \mathrm{MHz}$ spectrometer equipped with a Cryoprobe. The pulse sequence provided in the Varian BioPack library of pulse programmes was used. The NMR samples were prepared in $90 \%$ $\mathrm{H}_{2} \mathrm{O} / 10 \%$ DMSO- $d_{6}$ buffer containing $20 \mathrm{mM}$ HEPES, $7 \mathrm{mM}$ $\left(\mathrm{NH}_{4}\right)_{2} \mathrm{SO}_{4}, 3.5 \mathrm{mM} \mathrm{MgCl}_{2}, 0.3 \mathrm{mM}$ dithiothreitol, and $0.4 \mathrm{mM}$ ATP, $\mathrm{pH}$ 7.2. The MurD selectively labelled with ${ }^{13} \mathrm{C}$ at the methyl groups of Ile ( $\delta 1$ only), Val and Leu was at $0.07 \mathrm{mM}$. The MurD was titrated by the ligands for MurD:ligand molar ratios of 0.5, 1, 2, 5 and 10 . The spectra were acquired with 1024 data points in $t_{2}, 32$ scans, 64 complex points in $t_{1}$, and a relaxation delay of $1 \mathrm{~s}$. The ${ }^{1} \mathrm{H}$ and ${ }^{13} \mathrm{C}$ sweep widths were 9470 and $3340 \mathrm{~Hz}$, respectively. The spectra were processed with the NMRPipe software [47] and analysed with the Sparky software [48]. The spectra were zero-filled twice and apodised with a squared sine bell function shifted by $\pi / 2$ in both dimensions, using linear prediction of the data in the incremented dimension. The combined chemical shift changes, which include information of both involved nuclei and are more convenient to analyze ${ }^{1} \mathrm{H} /{ }^{13} \mathrm{C}$ HSQC data, were used [49]. The combined chemical shift changes $\Delta \delta^{1} \mathrm{H} /{ }^{13} \mathrm{C}$ were calculated from ${ }^{1} \mathrm{H}$ to ${ }^{13} \mathrm{C}$ chemical shift changes using the equation: $\Delta \delta^{1} \mathrm{H} /{ }^{13} \mathrm{C}=\left(\left(\Delta \delta^{1} \mathrm{H}\right)^{2}\right.$ $\left.+\left(0.252 \times \Delta \delta^{13} \mathrm{C}\right)^{2}\right)^{1 / 2}$ where 0.252 is the weighting factor $w$ which accounts for differences in sensitivity of ${ }^{1} \mathrm{H}$ and ${ }^{13} \mathrm{C}$ resonances [50]. It is expressed as: $w=\left|\gamma_{13 \mathrm{C}}\right| /\left|\gamma_{1 \mathrm{H}}\right|$ where $\gamma_{13 \mathrm{C}}$ and $\gamma_{1 \mathrm{H}}$ are magnetogyric ratios of ${ }^{13} \mathrm{C}$ nucleus and the proton, respectively [49].

\subsection{Crystallisation, preparation of the inhibitor complex, and data collection}

Crystals of conformationally closed MurD ligase were obtained by co-crystallising MurD at $293 \mathrm{~K}$ with UMA and a nonhydrolysable analogue of ATP (AMP-PNP) [11,12,32]. The crystals were obtained using the vapour-diffusion method and a hangingdrop system in Linbro plates, by mixing drops of $2 \mu \mathrm{L}$ of MurD solution ( $3 \mathrm{mg} / \mathrm{mL}$ purified enzyme, $20 \mathrm{mM}$ HEPES, pH 7.4, $200 \mathrm{mM}$ $\mathrm{NaCl}, 5 \mathrm{mM}$ dithiothreitol, $1 \mathrm{mM}$ UMA and $5 \mathrm{mM}$ AMP-PNP) and $2 \mu \mathrm{L}$ of reservoir solution (0.1 M HEPES, $\mathrm{pH}$ 7.5, 1.9 M ammonium sulphate, 7\% (w/v) PEG 400 and $50 \mathrm{mM} \mathrm{NaCl}$ ). The crystals were grown over 6 days, and subsequently incubated with $1.5 \mathrm{mM}$ compound 32d in $2 \%(\mathrm{v} / \mathrm{v})$ DMSO for $36 \mathrm{~h}$. After these $36 \mathrm{~h}$ of soaking, the crystals were rapidly frozen in liquid nitrogen, using Paratone oil as a cryoprotectant. The dataset was collected with the ID14-EH2 beamline at the European Synchrotron Radiation Facility (Grenoble, France).

\subsection{Materials and methods. Chemistry}

Reagents and solvents were obtained from commercial sources (Fluka, Sigma-Aldrich, Acros Organics, Alfa Aesar, Fluorochem). Solvents were distilled before use, while the other chemicals were used as received. All of the reactions were carried out under an argon atmosphere with magnetic stirring, unless otherwise stated. Microwave-assisted reactions were performed using a focused microwave reactor (Discover, CEM Corporation, Matthews, NC, USA). Hydrogenation reactions were performed using a Parr 4842 hydrogenation apparatus. Analytical TLC was performed on Merck 
silica gel $\left(60 \mathrm{~F}_{254}\right)$ pre-coated plates $(0.25 \mathrm{~mm})$. The compounds were visualised under UV light and/or stained with the relevant reagent. Column chromatography was performed on Merck silica gel 60 (mesh 70-230), using the indicated solvents. Yields refer to the purified products, and they were not optimised. All of the melting points were determined on a Reichert hot-stage apparatus, and are uncorrected. Optical rotation was measured on a Perkin-Elmer $1241 \mathrm{MC}$ polarimeter. ${ }^{1} \mathrm{H}$ NMR spectra were recorded on a Bruker Avance 300 DPX spectrometer at $302 \mathrm{~K}$, and are reported in ppm using tetramethylsilane or solvent as an internal standard (DMSO- $d_{6}$ at $2.50 \mathrm{ppm}, \mathrm{CDCl}_{3}$ at $7.26 \mathrm{ppm}$ ). The coupling constants $(J)$ are given in $\mathrm{Hz}$, and the splitting patterns are designated as: $\mathrm{s}$, singlet; bs, broad singlet; d, doublet; dd, double doublet; t, triplet; and $\mathrm{m}$, multiplet. ${ }^{13} \mathrm{C}$ NMR spectra were recorded on a Bruker Avance $400 \mathrm{DPX}$ spectrometer at $302 \mathrm{~K}$, and are reported in ppm using solvent as an internal standard (DMSO- $d_{6}$ at $39.5 \mathrm{ppm}, \mathrm{CDCl}_{3}$ at $77.0 \mathrm{ppm})$. Mass spectra data and high-resolution mass measurements were performed on a VG-Analytical Autospec Q mass spectrometer. Elemental analyses were performed on a $240 \mathrm{C}$ Perkin-Elmer C, H, N analyser. HPLC analyses were run on an Agilent 1100 system equipped with a quaternary pump and a multiple wavelength detector. Reversed-phase HPLC was performed on a Kinetex C18, $2.6 \mu \mathrm{m}(100 \times 4.6 \mathrm{~mm})$ column (Phenomenex, Torrance, CA, USA). Chiral HPLC was performed on a Kromasil 3-CelluCoat RP, $3 \mu \mathrm{m}(150 \times 4.6 \mathrm{~mm})$ column (AkzoNobel, Eka Chemicals, Bohus, Sweden) and on a Chirex (S)-tertleucine and 3,5-dinitroaniline, $5 \mu \mathrm{m}(150 \times 4.6 \mathrm{~mm})$ column (Phenomenex, Torrance, CA, USA). The purity of all new compounds was determined by elemental analyses and some compounds also additionally by HPLC. Analyses indicated by the symbols of the elements were within $\pm 0.4 \%$ of the theoretical values.

\subsection{Experimental procedures}

\subsubsection{Synthesis of diethyl 4-aminocyclohexane-1,3-dicarboxylate} (12d) (14).

Step 1. Diethyl 4-oxocyclohexane-1,3-dicarboxylate, racemate

Sodium was slowly added to a stirred solution of compound $\mathbf{1 3}$ $(1.15 \mathrm{~g}, 4.00 \mathrm{mmol})$ in toluene $(10 \mathrm{~mL})$. After heating the mixture to $90{ }^{\circ} \mathrm{C}$, absolute EtOH $(100 \mu \mathrm{L})$ was added, and the mixture refluxed for $8 \mathrm{~h}$. After the reaction was complete, it was cooled and poured into a mixture of ice and dilute $\mathrm{HCl}$. The organic layer was then collected, and the aqueous layer extracted with toluene $(2 \times 15 \mathrm{~mL})$. The combined toluene layers were washed with saturated aqueous $\mathrm{NaHCO}_{3}(3 \times 30 \mathrm{~mL})$ and then $\mathrm{H}_{2} \mathrm{O}(2 \times 30 \mathrm{~mL})$, and dried over $\mathrm{Na}_{2} \mathrm{SO}_{4}$ and filtered. The solvent was evaporated under reduced pressure to yield the pure product 14 as a yellow oil ( $852 \mathrm{mg}, 88 \%$ ). $[\alpha]_{\mathrm{D}}{ }^{20}:+0.8\left(\mathrm{c} 0.163, \mathrm{CH}_{2} \mathrm{Cl}_{2}\right) ;{ }^{1} \mathrm{H}$ NMR $\left(300 \mathrm{MHz}, \mathrm{CDCl}_{3}\right.$, mixture of keto-enol tautomers): $\delta 1.21-1.36\left(\mathrm{~m}, 6 \mathrm{H}, 2 \times \mathrm{CH}_{2} \mathrm{CH}_{3}\right), 1.63-1.88$ (m, 1H, cyclohexyl- $H$ ), 1.95-2.62 ( $\mathrm{m}, 6 \mathrm{H}$, cyclohexyl- $H$ ), 2.68-2.93 and $12.22(\mathrm{~m}$ and $\mathrm{s}, 1 \mathrm{H}$, cyclohexyl- $\mathrm{H}$ and $\mathrm{OH}), 4.09-4.30(\mathrm{~m}, 4 \mathrm{H}$, $2 \times \mathrm{CH}_{2} \mathrm{CH}_{3}$ ); HRMS (ESI) $\mathrm{m} / z$ calcd for $\mathrm{C}_{12} \mathrm{H}_{19} \mathrm{O}_{5}[\mathrm{M}+\mathrm{H}]^{+} 243.1232$, found 243.1235. Purity by HPLC $>99 \%$.

Step 2.

Method 1. (E/Z)-Diethyl 4-(hydroxyimino)cyclohexane-1,3-dicarboxylate, racemate (15) [37].

To a solution of $14(689 \mathrm{mg}, 2.85 \mathrm{mmol})$ in EtOH $(7 \mathrm{~mL})$, hydroxylamine hydrochloride $(285.2 \mathrm{mg}, 4.10 \mathrm{mmol})$ in $\mathrm{H}_{2} \mathrm{O}(2 \mathrm{~mL})$ was added during continuous stirring. After $5 \mathrm{~min}$, a solution of $\mathrm{Na}_{2} \mathrm{CO}_{3}(217.3 \mathrm{mg}, 2.05 \mathrm{mmol})$ in $\mathrm{H}_{2} \mathrm{O}(3 \mathrm{~mL})$ was added drop-wise and the mixture was stirred for an additional $1 \mathrm{~h}$. After the reaction was complete, the mixture was diluted with $\mathrm{H}_{2} \mathrm{O}$, and extracted with $\mathrm{Et}_{2} \mathrm{O}(3 \times 15 \mathrm{~mL})$. The combined organic extracts were dried over $\mathrm{Na}_{2} \mathrm{SO}_{4}$, filtered, and evaporated to dryness, yielding a yellow oil. The crude product was purified by column chromatography $\left(\mathrm{CH}_{2} \mathrm{Cl}_{2} / \mathrm{MeOH} 1 / 15\right)$, to yield a colourless oil that formed a precipitate upon addition of hexane. Unstable white solid (265 mg, 32\%); mp: 62-64 ${ }^{\circ} \mathrm{C}$ (lit. [37] 64-65 ${ }^{\circ} \mathrm{C}$ ); ${ }^{1} \mathrm{H}$ NMR (300 $\mathrm{MHz}, \mathrm{CDCl}_{3}$, mixture of $E$ - and Z-isomers): $\delta 1.21-1.32\left(\mathrm{~m}, 6 \mathrm{H}, 2 \times \mathrm{CH}_{2} \mathrm{CH}_{3}\right)$, 1.51-1.95 (m, 3H, cyclohexyl- $H$ ), 2.03-2.59 (m, 3H, cyclohexyl- $H$ ), 3.13-3.28 ( $\mathrm{m}, 1 \mathrm{H}$, cyclohexyl- $H)$, 3.35-3.52 (m, 1H, cyclohexyl- $H)$, 4.06-4.27 (m, $\left.4 \mathrm{H}, 2 \times \mathrm{CH}_{2} \mathrm{CH}_{3}\right), 7.80$ and 7.99 (br s, $1 \mathrm{H}, \mathrm{NOH}, \mathrm{E}$ - and $Z$-isomer); HRMS (ESI) $\mathrm{m} / z$ calcd for $\mathrm{C}_{12} \mathrm{H}_{19} \mathrm{NO}_{5} \mathrm{Na}[\mathrm{M}+\mathrm{Na}]^{+}$ 280.1174, found 280.1164 .

Method 2. Diethyl 4-(benzylamino)cyclohexane-1,3-dicarboxylate, racemate $(\mathbf{1 6})$.

$\mathrm{Na}(\mathrm{OAc}) \mathrm{BH}_{3}(847 \mathrm{mg}, 4.00 \mathrm{mmol})$ and $\mathrm{AcOH}(172 \mathrm{mg}$, $2.86 \mathrm{mmol}$ ) were consecutively added to a stirred solution of compound $14(692 \mathrm{mg}, 2.86 \mathrm{mmol})$ and benzylamine $(288 \mathrm{mg}$, $2.86 \mathrm{mmol})$ in 1,2-dichloroethane $(10 \mathrm{~mL})$. When the starting synthone disappeared (monitored by TLC), saturated aqueous $\mathrm{NaHCO}_{3}(10 \mathrm{~mL})$ was added, and the mixture extracted with $\mathrm{Et}_{2} \mathrm{O}$ $(3 \times 30 \mathrm{~mL})$. The combined organic extracts were washed with brine, dried over $\mathrm{Na}_{2} \mathrm{SO}_{4}$, and filtered. The solvent was evaporated under reduced pressure and the residue was purified by column chromatography (EtOAc/hexane $1 / 3$ ) to yield the pure product $\mathbf{1 6}$ as a white solid (686 mg, 72\%). Mp: $52.0-53.5^{\circ} \mathrm{C} ;[\alpha]_{\mathrm{D}}{ }^{20}:+1.5($ c 0.149 , $\left.\mathrm{CH}_{2} \mathrm{Cl}_{2}\right) ;{ }^{1} \mathrm{H}$ NMR $\left(300 \mathrm{MHz}, \mathrm{CDCl}_{3}\right): \delta 1.21-1.30(\mathrm{~m}, 6 \mathrm{H}$, $\left.2 \times \mathrm{CH}_{2} \mathrm{CH}_{3}\right), 1.32-1.45(\mathrm{~m}, 1 \mathrm{H}$, cyclohexyl- $\mathrm{H}), 1.71-1.87(\mathrm{~m}, 2 \mathrm{H}$, cyclohexyl- $H), 1.91-2.12(\mathrm{~m}, 3 \mathrm{H}$, cyclohexyl- $H), 2.29-2.39(\mathrm{~m}, 1 \mathrm{H}$ cyclohexyl- $H$ ), 2.47-2.57 ( $\mathrm{m}, 1 \mathrm{H}$, cyclohexyl- $H$ ), $3.30(\mathrm{q}, J=3.1 \mathrm{~Hz}$, $1 \mathrm{H}$, cyclohexyl- $H)$, 3.66 and $3.84\left(\mathrm{AB}, J_{\mathrm{AB}}=13.3 \mathrm{~Hz}, 2 \mathrm{H}, \mathrm{NHCH}_{2}\right)$, 4.07-4.22 (m, $\left.4 \mathrm{H}, 2 \times \mathrm{CH}_{2} \mathrm{CH}_{3}\right), 7.20-7.35(\mathrm{~m}, 5 \mathrm{H}, \mathrm{Ar}-\mathrm{H})$, resonance for $\mathrm{NH}$ missing; HRMS (ESI) $m / z$ calcd for $\mathrm{C}_{19} \mathrm{H}_{28} \mathrm{NO}_{4}[\mathrm{M}+\mathrm{H}]^{+}$ 334.2018, found 334.2010; Anal. $\left(\mathrm{C}_{19} \mathrm{H}_{27} \mathrm{NO}_{4}\right) \mathrm{C}, \mathrm{H}, \mathrm{N}$. (12d).

Step 3. Diethyl 4-aminocyclohexane-1,3-dicarboxylate, racemate

Method 1. To a solution of the oxime $\mathbf{1 5}(252 \mathrm{mg}, 0.98 \mathrm{mmol})$ in $i$-PrOH $(10 \mathrm{~mL})$, Raney-Ni $(25 \mathrm{mg})$ was added, and the mixture was hydrogenated for $2 \mathrm{~h}$ under reflux. The catalyst was then filtered out and the filtrate evaporated under reduced pressure. The crude product was purified by column chromatography $\left(\mathrm{CH}_{2} \mathrm{Cl}_{2} / \mathrm{MeOH} 20 / 1\right)$ to yield $\mathbf{1 2 d}$ as a yellow oil (138 $\left.\mathrm{mg}, 58 \%\right)$. The detailed spectroscopic data for the compound obtained with Method 2 is described below.

Method 2. To a solution of compound $16(382 \mathrm{mg}, 1.15 \mathrm{mmol})$ in EtOH $(50 \mathrm{~mL}), 10 \% \mathrm{Pd} / \mathrm{C}(70 \mathrm{mg})$ was added, and the mixture was hydrogenated for $48 \mathrm{~h}$ at 20 bar in a Parr hydrogenation apparatus. The suspension was then filtered through a pad of celite and washed with EtOH $(40 \mathrm{~mL})$. The solvent was removed under reduced pressure and the residue purified by column chromatography $\left(\mathrm{CH}_{2} \mathrm{Cl}_{2} / \mathrm{MeOH} 9 / 1\right)$ to yield the pure product $12 \mathrm{~d}$ as a yellow

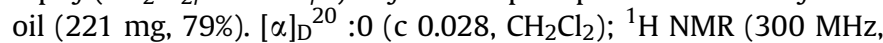
$\left.\mathrm{CDCl}_{3}\right): \delta 1.21-1.31\left(\mathrm{~m}, 6 \mathrm{H}, 2 \times \mathrm{CH}_{2} \mathrm{CH}_{3}\right), 1.58-1.87(\mathrm{~m}, 4 \mathrm{H}$, cyclohexyl-H), 1.89-2.10 (m, 2H, cyclohexyl-H), 2.23-2.35 (m, 1H, cyclohexyl-H), 2.44-2.55 ( $\mathrm{m}, 1 \mathrm{H}$, cyclohexyl-H), $3.53(\mathrm{q}, J=3.0 \mathrm{~Hz}$, $1 \mathrm{H}$, cyclohexyl-H), $4.08-4.26\left(\mathrm{~m}, 4 \mathrm{H}, 2 \times \mathrm{CH}_{2} \mathrm{CH}_{3}\right)$, resonance for $\mathrm{NH}_{2}$ missing; HRMS (ESI) $m / z$ calcd for $\mathrm{C}_{12} \mathrm{H}_{22} \mathrm{NO}_{4}[\mathrm{M}+\mathrm{H}]^{+}$ 244.1549, found 244.1558.

\subsubsection{Synthesis of dimethyl 4-aminoisophthalate (12i)}

Step 1. Method 1. 4-(benzylamino)isophthalic acid (18) [39].

A mixture of 4-bromoisophthalic acid (17) (1.23 g, $5.00 \mathrm{mmol}$ ), benzylamine (1.03 g, $10.00 \mathrm{mmol}), \mathrm{K}_{2} \mathrm{CO}_{3}(691.1 \mathrm{mg}, 5.00 \mathrm{mmol})$, $\mathrm{Cu}$ powder $(28.9 \mathrm{mg}, 0.46 \mathrm{mmol})$, and $\mathrm{Cu}_{2} \mathrm{O}(32.5 \mathrm{mg}, 0.23 \mathrm{mmol})$ in 2-ethoxyethanol $(3 \mathrm{~mL})$ was irradiated at $130{ }^{\circ} \mathrm{C}(5 \mathrm{MW}$ power) for $45 \mathrm{~min}$ in a sealed tube ( $10 \mathrm{~mL}$ pressure-rated reaction vial). The mixture was cooled rapidly to room temperature, the solvent removed under reduced pressure, and then $\mathrm{H}_{2} \mathrm{O}(30 \mathrm{~mL})$ added to 
the residue. The mixture was treated with charcoal and filtered through a pad of celite. The filtrate was acidified ( $\mathrm{pH} 5$ ) with $1 \mathrm{M}$ $\mathrm{HCl}$ to give a precipitate, which was dissolved in aqueous $\mathrm{Na}_{2} \mathrm{CO}_{3}$ $(5 \%, 50 \mathrm{~mL})$, and filtrated through a pad of celite. The solution was again acidified ( $\mathrm{pH} 4$ ) with $1 \mathrm{M} \mathrm{HCl}$ to provide the solid 18, which was filtered off, dried, and used in the next step without further purification. Pale brown solid (190 mg, 21\%); ${ }^{1} \mathrm{H}$ NMR $(300 \mathrm{MHz}$, DMSO-d $\left.d_{6}\right): \delta 4.54\left(\mathrm{~s}, 2 \mathrm{H}, \mathrm{NHCH}_{2}\right), 6.75(\mathrm{~d}, J=9.0 \mathrm{~Hz}, 1 \mathrm{H}, \mathrm{Ar}-\mathrm{H})$, 7.31-7.37 (m, 5H, Ar- $H$ ), 7.82 (dd, $J=8.9,2.0 \mathrm{~Hz}, 1 \mathrm{H}, \mathrm{Ar}-H), 8.44$ (s, $1 \mathrm{H}, \mathrm{Ar}-\mathrm{H}$ ), 8.75 (br s, $1 \mathrm{H}, \mathrm{NHCH}_{2}$ ), 12.86 (br s, $2 \mathrm{H}, 2 \times \mathrm{COOH}$ ); HRMS (ESI) $m / z$ calcd for $\mathrm{C}_{15} \mathrm{H}_{12} \mathrm{NO}_{4}[\mathrm{M}-\mathrm{H}]^{-} 270.0766$, found 270.0774 .

Step 2. Method 1. Dimethyl 4-(benzylamino)isophthalate (19).

To an ice-cooled solution of 18 (425 mg, $1.57 \mathrm{mmol})$ in $\mathrm{MeOH}$ $(15 \mathrm{~mL}), \mathrm{SOCl}_{2}(1.87 \mathrm{~g}, 15.70 \mathrm{mmol})$ was slowly added with continuous stirring. The mixture was stirred at room temperature for 2 days. After the reaction was complete (monitored by TLC), the solvent was evaporated, and saturated aqueous $\mathrm{NaHCO}_{3}(20 \mathrm{~mL})$ was added to the residue. The aqueous phase was extracted with EtOAc $(3 \times 20 \mathrm{~mL})$, and the combined organic phases were washed with brine $(2 \times 20 \mathrm{~mL})$, dried over $\mathrm{Na}_{2} \mathrm{SO}_{4}$, filtered, and removed under reduced pressure. The resulting residue was purified by column chromatography (EtOAc/hexane $1 / 3$ ) to provide 19 as a white solid (328 mg, 70\%). Mp: 79.0-83.0 ${ }^{\circ} \mathrm{C} ;{ }^{1} \mathrm{H}$ NMR $(300 \mathrm{MHz}$, $\left.\mathrm{CDCl}_{3}\right): \delta 3.86\left(\mathrm{~s}, 3 \mathrm{H}, \mathrm{CH}_{3}\right), 3.89\left(\mathrm{~s}, 3 \mathrm{H}, \mathrm{CH}_{3}\right), 4.50(\mathrm{~d}, J=5.6 \mathrm{~Hz}, 2 \mathrm{H}$, $\mathrm{NHCH}_{2}$ ), 6.65 (d, $\left.J=9.0 \mathrm{~Hz}, 1 \mathrm{H}, \mathrm{Ar}-\mathrm{H}\right), 7.29-7.39$ (m, 5H, Ar- H), 7.94 (dd, $J=8.9,2.0 \mathrm{~Hz}, 1 \mathrm{H}, \mathrm{Ar}-H), 8.64(\mathrm{~s}, 1 \mathrm{H}, \mathrm{Ar}-\mathrm{H}), 8.69$ (br s, $1 \mathrm{H}$, $\mathrm{NHCH}_{2}$ ); HRMS (ESI) $m / z$ calcd for $\mathrm{C}_{17} \mathrm{H}_{18} \mathrm{NO}_{4}[\mathrm{M}+\mathrm{H}]^{+} 300.1236$, found 300.1228; Anal. $\left(\mathrm{C}_{17} \mathrm{H}_{17} \mathrm{NO}_{4}\right) \mathrm{C}, \mathrm{H}, \mathrm{N}$.

Step 3. Method 1. Dimethyl 4-aminoisophthalate (12i) [40].

To a solution of compound 19 (300 $\mathrm{mg}, 1.00 \mathrm{mmol}$ ) in $\mathrm{MeOH}$ (15 mL), 10\% Pd-C (30 mg) was added, and the mixture was hydrogenated for $10 \mathrm{~h}$ at room temperature. The suspension was then filtered through a pad of celite and washed with $\mathrm{MeOH}$ $(20 \mathrm{~mL})$. The solvent was evaporated under reduced pressure, yielding the pure product $12 \mathbf{i}$ as a white solid (178 $\mathrm{mg}, 85 \%)$. Mp: 126.5-127.0 ${ }^{\circ} \mathrm{C}$ (lit. [40] $\left.127-128{ }^{\circ} \mathrm{C}\right) ;{ }^{1} \mathrm{H}$ NMR (300 $\mathrm{MHz}, \mathrm{CDCl}_{3}$ ): $\delta 3.87\left(\mathrm{~s}, 3 \mathrm{H}, \mathrm{CH}_{3}\right), 3.89\left(\mathrm{~s}, 3 \mathrm{H}, \mathrm{CH}_{3}\right), 6.20\left(\mathrm{br} \mathrm{s}, 2 \mathrm{H}, \mathrm{NH}_{2}\right), 6.64(\mathrm{~d}$, $J=8.7 \mathrm{~Hz}, 1 \mathrm{H}, \operatorname{Ar}-H), 7.90(\mathrm{dd}, J=8.7,2.1 \mathrm{~Hz}, 1 \mathrm{H}, \operatorname{Ar}-H), 8.58(\mathrm{~d}$, $J=2.1 \mathrm{~Hz}, 1 \mathrm{H}, \mathrm{Ar}-\mathrm{H}$ ); HRMS (ESI) $m / z$ calcd for $\mathrm{C}_{10} \mathrm{H}_{12} \mathrm{NO}_{4}[\mathrm{M}+\mathrm{H}]^{+}$ 210.0766, found 210.0769.

\subsubsection{Experimental procedure for the synthesis of 6-substituted naphthalene-2-sulfonamides $\mathbf{3 1 a}-\boldsymbol{i}$ and $\mathbf{3 2 a}-\boldsymbol{i}$}

The target compounds were prepared from sulfonyl chlorides 27 and $\mathbf{2 8}$ in two consecutive steps; these were synthesised from the appropriate starting materials following literature procedures [34], and from commercially available or synthesised aromatic or cyclic aliphatic amines 12a-i.

Step 1. Formation of protected 6-substituted naphthalene-2sulfonamides (29a-i, 30a-i).

Method 1 (29a-e, 30a-e, and 29g, 30g).

Sulfonyl chloride $\mathbf{2 7}$ or $\mathbf{2 8}(1.00 \mathrm{mmol})$ was dissolved in $\mathrm{CH}_{2} \mathrm{Cl}_{2}$ $(5 \mathrm{~mL})$ and slowly added to a solution of the appropriate amine $12 \mathrm{a}-\mathbf{e}$ or $12 \mathrm{~g}(1.20 \mathrm{mmol})$ in $\mathrm{CH}_{2} \mathrm{Cl}_{2}(5 \mathrm{~mL})$, followed by the addition of $\mathrm{Et}_{3} \mathrm{~N}(2.50 \mathrm{mmol})$ after $10 \mathrm{~min}$. The reaction mixture was stirred at room temperature for $24 \mathrm{~h}$, or until the reaction was complete (monitored by TLC), quenched with $1 \mathrm{M} \mathrm{HCl}(15 \mathrm{~mL})$, and extracted with $\mathrm{CH}_{2} \mathrm{Cl}_{2}(3 \times 30 \mathrm{~mL})$. The combined organic layers were washed with brine, dried over $\mathrm{Na}_{2} \mathrm{SO}_{4}$, filtered, and evaporated under reduced pressure, giving a residue that was purified by column chromatography, to obtain compounds $\mathbf{2 9 a}-\mathbf{e}, \mathbf{3 0 a}-\mathbf{e}$, and 29g, 30g.

Method 2 (29f, 30f).

Sulfonyl chloride $\mathbf{2 7}$ or $\mathbf{2 8}$ (1.00 $\mathrm{mmol}$ ) was dissolved in dry THF $(5 \mathrm{~mL})$ and slowly added to a solution of amine $\mathbf{1 2 f}(1.20 \mathrm{mmol})$ in dry THF ( $5 \mathrm{~mL})$, followed by the addition of $\mathrm{Et}_{3} \mathrm{~N}(2.50 \mathrm{mmol})$ after $10 \mathrm{~min}$. After the reaction was complete (monitored by TLC), the solvent was removed under reduced pressure, and then $1 \mathrm{M} \mathrm{HCl}$ (15 $\mathrm{mL}$ ) was added and the product extracted with $\mathrm{CH}_{2} \mathrm{Cl}_{2}$ $(3 \times 30 \mathrm{~mL})$. The combined organic phases were washed with brine $(2 \times 30 \mathrm{~mL})$, dried over $\mathrm{Na}_{2} \mathrm{SO}_{4}$, filtered, and evaporated under reduced pressure. The resulting crude products were purified by column chromatography, to yield compounds $29 f$ and $30 f$.

Method 3 (29h, 30h).

Sulfonyl chloride $\mathbf{2 7}$ or $\mathbf{2 8}(1.00 \mathrm{mmol})$ was slowly added to a solution of $\mathbf{1 2 h}(1.20 \mathrm{mmol})$ in EtOH $(10 \mathrm{~mL})$, followed by the addition of $\mathrm{Et}_{3} \mathrm{~N}(2.50 \mathrm{mmol})$ after $10 \mathrm{~min}$. The reaction mixture was stirred for 2 days at $55{ }^{\circ} \mathrm{C}$. After the reaction was complete (monitored by TLC), the solvent was removed under reduced pressure, and then $1 \mathrm{M} \mathrm{HCl}(15 \mathrm{~mL})$ was added and the product extracted with $\mathrm{CH}_{2} \mathrm{Cl}_{2}(3 \times 30 \mathrm{~mL})$. The combined organic phases were washed with brine $(2 \times 30 \mathrm{~mL})$, dried over $\mathrm{Na}_{2} \mathrm{SO}_{4}$, filtered and evaporated under reduced pressure. The resulting crude products were purified by column chromatography, to yield compounds 29a, 30a and 29h, 30h.

Method 4 (29i, 30i).

Sulfonyl chloride $\mathbf{2 7}$ or $\mathbf{2 8}$ (1.00 mmol) was dissolved in $\mathrm{CH}_{2} \mathrm{Cl}_{2}$ $(5 \mathrm{~mL})$ and slowly added to a solution of amine $\mathbf{1 2} \mathbf{i}(1.20 \mathrm{mmol})$ in $\mathrm{CH}_{2} \mathrm{Cl}_{2}$ (5 mL), followed by the addition of Py $(2.50 \mathrm{mmol})$ after $10 \mathrm{~min}$. The reaction mixture was stirred for 2 days at $50{ }^{\circ} \mathrm{C}$. After the reaction was complete (monitored by TLC), $1 \mathrm{M} \mathrm{HCl}(15 \mathrm{~mL})$ was added and the product extracted with $\mathrm{CH}_{2} \mathrm{Cl}_{2}(3 \times 30 \mathrm{~mL})$. The combined organic phases were washed with brine $(2 \times 30 \mathrm{~mL})$, dried over $\mathrm{Na}_{2} \mathrm{SO}_{4}$, filtered, and evaporated under reduced pressure. The resulting crude products were purified by column chromatography, to yield compounds $29 \mathbf{i}$ and $\mathbf{3 0 i}$.

5.6.3.1. Methyl 1-(6-butoxynaphthalen-2-ylsulfonyl)piperidine-4-carboxylate (29a). Purification on $\mathrm{SiO}_{2}$ (EtOAc/hexane 1/3) gave $279 \mathrm{mg}$ (76\%) of a white solid. Mp: $132.0-133.5{ }^{\circ} \mathrm{C} ;{ }^{1} \mathrm{H}$ NMR $\left(300 \mathrm{MHz}, \mathrm{CDCl}_{3}\right): \delta 1.01$ $\left(\mathrm{t}, J=7.4 \mathrm{~Hz}, 3 \mathrm{H}, \mathrm{CH}_{2} \mathrm{CH}_{3}\right), 1.48-1.62\left(\mathrm{~m}, 2 \mathrm{H}, \mathrm{CH}_{2} \mathrm{CH}_{3}\right), 1.75-1.91(\mathrm{~m}, 4 \mathrm{H}$, $\mathrm{OCH}_{2} \mathrm{CH}_{2}$ and piperidyl- $H$ ), 1.92-2.02 (m, $2 \mathrm{H}$, piperidyl- $H$ ), 2.18-2.29 (m, $1 \mathrm{H}$, piperidyl- $H$ ), 2.52 (td, $J=11.5,2.8 \mathrm{~Hz}, 2 \mathrm{H}$, piperidyl- $H$ ), $3.64(\mathrm{~s}$, $\left.3 \mathrm{H}, \mathrm{CH}_{3}\right), 3.70(\mathrm{dt}, J=11.8,3.6 \mathrm{~Hz}, 2 \mathrm{H}$, piperidyl $-H), 4.11(\mathrm{t}, J=6.5 \mathrm{~Hz}, 2 \mathrm{H}$, $\mathrm{OCH}_{2}$ ), 7.17 (d, $J=2.4 \mathrm{~Hz}, 1 \mathrm{H}$, Naph- $H$ ), 7.26 (dd, $J=8.9,2.4 \mathrm{~Hz}, 1 \mathrm{H}$, Naph- $H$ ), 7.69 (dd, $J=8.6,1.7 \mathrm{~Hz}, 1 \mathrm{H}$, Naph- $H$ ), 7.81 (d, $J=8.6 \mathrm{~Hz}, 1 \mathrm{H}$, Naph- $H$ ), 7.85 (d, $J=8.9 \mathrm{~Hz}, 1 \mathrm{H}$, Naph- $H$ ), 8.23 (d, $J=1.7 \mathrm{~Hz}, 1 \mathrm{H}$, Naph$H$ ); HRMS (ESI) $m / z$ calcd for $\mathrm{C}_{21} \mathrm{H}_{28} \mathrm{NO}_{5} \mathrm{~S}[\mathrm{M}+\mathrm{H}]^{+} 406.1688$, found 406.1674; Anal. $\left(\mathrm{C}_{21} \mathrm{H}_{27} \mathrm{NO}_{5} \mathrm{~S}\right) \mathrm{C}, \mathrm{H}, \mathrm{N}$.

5.6.3.2. (1R,2S)-ethyl 2-(6-butoxynaphthalene-2-sulfonamido)cyclohexanecarboxylate (29b). Purification on $\mathrm{SiO}_{2}$ (EtOAc/hexane 1/3) gave $358 \mathrm{mg}(83 \%)$ of a white solid. Mp: $79.5-81.0{ }^{\circ} \mathrm{C} ;[\alpha]_{\mathrm{D}}{ }^{20}:+20.8$ (c $\left.0.268, \mathrm{CH}_{2} \mathrm{Cl}_{2}\right) ;{ }^{1} \mathrm{H} \mathrm{NMR}\left(300 \mathrm{MHz}, \mathrm{CDCl}_{3}\right): \delta 1.01(\mathrm{t}, J=7.4 \mathrm{~Hz}, 3 \mathrm{H}$, $\left.\mathrm{CH}_{2} \mathrm{CH}_{3}\right), 1.12\left(\mathrm{t}, J=7.1 \mathrm{~Hz}, 3 \mathrm{H}, \mathrm{OCH}_{2} \mathrm{CH}_{3}\right), 1.18-1.68\left(\mathrm{~m}, 8 \mathrm{H}, \mathrm{CH}_{2} \mathrm{CH}_{3}\right.$ and cyclohexyl-H), $1.70-2.02\left(\mathrm{~m}, 4 \mathrm{H}, \mathrm{OCH}_{2} \mathrm{CH}_{2}\right.$ and cyclohexyl- $\left.\mathrm{H}\right)$, $2.62(\mathrm{q}, J=4.7 \mathrm{~Hz}, 1 \mathrm{H}$, cyclohexyl-H), 3.48 (sym m, 1H, cyclohexyl$\mathrm{H}), 3.84-4.14\left(\mathrm{~m}, 4 \mathrm{H}, \mathrm{OCH}_{2}\right.$ and $\left.\mathrm{OCH}_{2} \mathrm{CH}_{3}\right), 5.60(\mathrm{~d}, J=8.7 \mathrm{~Hz}, 1 \mathrm{H}$, $\mathrm{NH}), 7.16(\mathrm{~d}, J=2.3 \mathrm{~Hz}, 1 \mathrm{H}$, Naph-H), 7.25 (dd, $J=8.9,2.3 \mathrm{~Hz}, 1 \mathrm{H}$, Naph-H), 7.74-7.81 (m, 2H, Naph-H), 7.83 (d, $J=8.9$ Hz, 1H, Naph$\mathrm{H}), 8.33$ (d, $J=1.6 \mathrm{~Hz}, 1 \mathrm{H}$, Naph-H); HRMS (ESI) $\mathrm{m} / z$ calcd for $\mathrm{C}_{23} \mathrm{H}_{32} \mathrm{NO}_{5} \mathrm{~S}[\mathrm{M}+\mathrm{H}]^{+}$434.2001, found 434.1989; Anal $\left(\mathrm{C}_{23} \mathrm{H}_{31} \mathrm{NO}_{5} \mathrm{~S}\right) \mathrm{C}, \mathrm{H}, \mathrm{N}$.

5.6.3.3. (1R,2R)-ethyl 2-(6-butoxynaphthalene-2-sulfonamido)cyclohexanecarboxylate (29c). Purification on $\mathrm{SiO}_{2}$ (EtOAc/hexane 1/3) gave $305 \mathrm{mg}(70 \%)$ of a white solid. Mp: $121.5-122.5{ }^{\circ} \mathrm{C}$; $[\alpha]_{\mathrm{D}}{ }^{20}:+10.5$ (c $0.194, \mathrm{CH}_{2} \mathrm{Cl}_{2}$ ); ${ }^{1} \mathrm{H}$ NMR (300 $\mathrm{MHz}, \mathrm{CDCl}_{3}$ ): $\delta$ 0.98-1.06 (m, 6H, $\mathrm{CH}_{2} \mathrm{CH}_{3}$ and $\left.\mathrm{OCH}_{2} \mathrm{CH}_{3}\right), 1.10-1.31(\mathrm{~m}, 3 \mathrm{H}$, cyclohexyl-H), $1.43-1.71\left(\mathrm{~m}, 5 \mathrm{H}, \mathrm{CH}_{2} \mathrm{CH}_{3}\right.$ and cyclohexyl-H), 
1.79-1.93 (m, 3H, $\mathrm{OCH}_{2} \mathrm{CH}_{2}$ and cyclohexyl-H), 2.01-2.11 (m, $1 \mathrm{H}$, cyclohexyl-H), 2.22 (td, $J=11.2,3.8 \mathrm{~Hz}, 1 \mathrm{H}$, cyclohexyl-H), 3.35-3.48 (m, 1H, cyclohexyl-H), 3.65-3.89 (m, $\left.2 \mathrm{H}, \mathrm{OCH}_{2} \mathrm{CH}_{3}\right)$, $4.11\left(\mathrm{t}, J=6.5 \mathrm{~Hz}, 2 \mathrm{H}, \mathrm{OCH}_{2}\right), 4.64(\mathrm{~d}, J=7.8 \mathrm{~Hz}, 1 \mathrm{H}, \mathrm{NH}), 7.15(\mathrm{~d}$, $J=2.3 \mathrm{~Hz}, 1 \mathrm{H}$, Naph-H), 7.25 (dd, $J=8.9,2.3 \mathrm{~Hz}, 1 \mathrm{H}$, Naph-H), 7.72-7.81 (m, 2H, Naph-H), 7.84 (d, $J=8.9 \mathrm{~Hz}, 1 \mathrm{H}$, Naph-H), $8.32\left(\mathrm{~d}, J=1.6 \mathrm{~Hz}, 1 \mathrm{H}\right.$, Naph-H); ${ }^{13} \mathrm{C}$ NMR $\left(100 \mathrm{MHz}, \mathrm{CDCl}_{3}\right)$ : $\delta$ 13.83, 13.89, 19.25, 24.04, 24.35, 28.46, 31.13, 33.74, 49.90, 54.26, $60.62,67.88,106.40,120.63,123.05,127.27,127.73,127.97$, 130.62, 135.36, 136.45, 159.33, 173.46; HRMS (ESI) $\mathrm{m} / \mathrm{z}$ calcd for $\mathrm{C}_{23} \mathrm{H}_{32} \mathrm{NO}_{5} \mathrm{~S}[\mathrm{M}+\mathrm{H}]^{+}$434.2001, found 434.2001; Anal. $\left(\mathrm{C}_{23} \mathrm{H}_{31} \mathrm{NO}_{5} \mathrm{~S}\right) \mathrm{C}, \mathrm{H}, \mathrm{N}$.

5.6.3.4. Diethyl 4-(6-butoxynaphthalene-2-sulfonamido)cyclohexane1,3-dicarboxylate, racemate (29d). Purification on $\mathrm{SiO}_{2}$ (EtOAc/ hexane $1 / 3$ ) gave $184 \mathrm{mg}$ (59\%) of a white solid. Mp: 98.0-99.0 ${ }^{\circ} \mathrm{C}$; $[\alpha]_{\mathrm{D}}^{20}:+1.1\left(c\right.$ 0.169, $\left.\mathrm{CH}_{2} \mathrm{Cl}_{2}\right) ;{ }^{1} \mathrm{H}$ NMR $\left(300 \mathrm{MHz}, \mathrm{CDCl}_{3}\right): \delta 0.94(\mathrm{t}$, $\left.J=7.1 \mathrm{~Hz}, 3 \mathrm{H}, \mathrm{OCH}_{2} \mathrm{CH}_{3}\right), 1.01\left(\mathrm{t}, J=7.4 \mathrm{~Hz}, 3 \mathrm{H}, \mathrm{CH}_{2} \mathrm{CH}_{3}\right), 1.25$ (t, $\left.J=7.1 \mathrm{~Hz}, 3 \mathrm{H}, \mathrm{OCH}_{2} \mathrm{CH}_{3}\right), 1.33-1.45(\mathrm{~m}, 1 \mathrm{H}$, cyclohexyl $-\mathrm{H}), 1.48-1.61$ $\left(\mathrm{m}, 2 \mathrm{H}, \mathrm{CH}_{2} \mathrm{CH}_{3}\right), 1.71-1.92\left(\mathrm{~m}, 5 \mathrm{H}, \mathrm{OCH}_{2} \mathrm{CH}_{2}\right.$ and cyclohexyl- $\mathrm{H}$ ), 1.94-2.05 (m, 1H, cyclohexyl- $H), 2.08-2.34(\mathrm{~m}, 2 \mathrm{H}$, cyclohexyl- $H)$, 2.47 (dt, $J=12.3,3.9 \mathrm{~Hz}, 1 \mathrm{H}$, cyclohexyl- $H$ ), 3.55 (sym m, $1 \mathrm{H}$, cyclohexyl- $\mathrm{H}), 3.68-3.92\left(\mathrm{~m}, 2 \mathrm{H}, \mathrm{OCH}_{2} \mathrm{CH}_{3}\right), 4.06-4.17\left(\mathrm{~m}, 4 \mathrm{H}, \mathrm{OCH}_{2}\right.$ and $\left.\mathrm{OCH}_{2} \mathrm{CH}_{3}\right), 5.18(\mathrm{~d}, J=6.0 \mathrm{~Hz}, 1 \mathrm{H}, \mathrm{NH}), 7.15(\mathrm{~d}, J=2.3 \mathrm{~Hz}, 1 \mathrm{H}$, Naph- $H$ ), 7.25 (dd, $J=8.9,2.3 \mathrm{~Hz}, 1 \mathrm{H}$, Naph- $H$ ), 7.73-7.82 (m, 2H, Naph-H), 7.84 (d, $J=8.9 \mathrm{~Hz}, 1 \mathrm{H}$, Naph-H), 8.32 (d, $J=1.6 \mathrm{~Hz}, 1 \mathrm{H}$, Naph- $H$ ); HRMS (ESI) $m / z$ calcd for $\mathrm{C}_{26} \mathrm{H}_{36} \mathrm{NO}_{7} \mathrm{~S}[\mathrm{M}+\mathrm{H}]^{+}$506.2212, found 506.2227; Anal. $\left(\mathrm{C}_{26} \mathrm{H}_{35} \mathrm{NO}_{7} \mathrm{~S}\right) \mathrm{C}, \mathrm{H}, \mathrm{N}$.

5.6.3.5. Methyl 2-(4-(6-butoxynaphthalene-2-sulfonamido)phenyl) acetate (29e). Purification on $\mathrm{SiO}_{2}($ EtOAc/hexane $1 / 5)$ gave $86 \mathrm{mg}$ (87\%) of a pale brown solid. Mp: $102.0-103.0{ }^{\circ} \mathrm{C} ;{ }^{1} \mathrm{H}$ NMR $\left(300 \mathrm{MHz}, \mathrm{CDCl}_{3}\right): \delta 1.00\left(\mathrm{t}, J=7.4 \mathrm{~Hz}, 3 \mathrm{H}, \mathrm{CH}_{2} \mathrm{CH}_{3}\right), 1.46-1.59(\mathrm{~m}$, $\left.2 \mathrm{H}, \mathrm{CH}_{2} \mathrm{CH}_{3}\right), 1.77-1.89\left(\mathrm{~m}, 2 \mathrm{H}, \mathrm{OCH}_{2} \mathrm{CH}_{2}\right), 3.52\left(\mathrm{~s}, 2 \mathrm{H}, \mathrm{CH}_{2} \mathrm{COO}\right)$, $3.65\left(\mathrm{~s}, 3 \mathrm{H}, \mathrm{CH}_{3}\right), 4.09\left(\mathrm{t}, J=6.5 \mathrm{~Hz}, 2 \mathrm{H}, \mathrm{OCH}_{2}\right), 6.52(\mathrm{br} \mathrm{s}, 1 \mathrm{H}, \mathrm{NH})$, 6.99-7.05 (m, 2H, Ar-H), 7.09-7.15 (m, 3H, Ar-H), 7.22 (dd, $J=8.9$, $2.4 \mathrm{~Hz}, 1 \mathrm{H}, \mathrm{Ar}-H$ ), 7.67 (dd, $J=8.6,1.7 \mathrm{~Hz}, 1 \mathrm{H}, \mathrm{Ar}-\mathrm{H}), 7.71-7.79(\mathrm{~m}$, $2 \mathrm{H}, \mathrm{Ar}-H), 8.24(\mathrm{~d}, J=1.7 \mathrm{~Hz}, 1 \mathrm{H}, \mathrm{Ar}-H)$; HRMS (ESI) $m / z$ calcd for $\mathrm{C}_{23} \mathrm{H}_{26} \mathrm{NO}_{5} \mathrm{~S}[\mathrm{M}+\mathrm{H}]^{+}$428.1532, found 428.1527; Anal. $\left(\mathrm{C}_{23} \mathrm{H}_{25} \mathrm{NO}_{5} \mathrm{~S}\right) \mathrm{C}, \mathrm{H}, \mathrm{N}$.

5.6.3.6. Methyl 2-(6-butoxynaphthalene-2-sulfonamido)-5-hydroxybenzoate (29f). Purification on $\mathrm{SiO}_{2}$ (EtOAc/hexane 3/5) gave $221 \mathrm{mg}(77 \%)$ of a yellow solid. Mp: $127.0-129.0{ }^{\circ} \mathrm{C} ;{ }^{1} \mathrm{H}$ NMR (300 MHz, DMSO- $\left.d_{6}\right): \delta 0.96\left(\mathrm{t}, J=7.4 \mathrm{~Hz}, 3 \mathrm{H}, \mathrm{CH}_{2} \mathrm{CH}_{3}\right), 1.41-1.56$ $\left(\mathrm{m}, 2 \mathrm{H}, \mathrm{CH}_{2} \mathrm{CH}_{3}\right), 1.77-1.89\left(\mathrm{~m}, 2 \mathrm{H}, \mathrm{OCH}_{2} \mathrm{CH}_{2}\right), 3.65\left(\mathrm{~s}, 3 \mathrm{H}, \mathrm{CH}_{3}\right), 4.15$ $\left(\mathrm{t}, J=6.5 \mathrm{~Hz}, 2 \mathrm{H}, \mathrm{OCH}_{2}\right), 6.64(\mathrm{~d}, J=9.0 \mathrm{~Hz}, 1 \mathrm{H}, \mathrm{Ar}-H), 6.72(\mathrm{~s}, 1 \mathrm{H}$, $\mathrm{OH}), 6.84$ (dd, $J=9.1,2.9 \mathrm{~Hz}, 1 \mathrm{H}, \mathrm{Ar}-H), 7.24$ (d, $J=2.8 \mathrm{~Hz}, 1 \mathrm{H}, \mathrm{Ar}-H)$, 7.32 (dd, $J=9.0,2.4 \mathrm{~Hz}, 1 \mathrm{H}, \mathrm{Ar}-H), 7.51(\mathrm{~d}, J=2.4 \mathrm{~Hz}, 1 \mathrm{H}, \mathrm{Ar}-\mathrm{H}), 7.76$ (dd, $J=8.7,1.9 \mathrm{~Hz}, 1 \mathrm{H}, \operatorname{Ar}-H), 8.04$ (d, $J=8.7 \mathrm{~Hz}, 1 \mathrm{H}, \operatorname{Ar}-H), 8.10$ (d, $J=9.0 \mathrm{~Hz}, 1 \mathrm{H}, \mathrm{Ar}-H), 8.41$ (d, $J=1.8 \mathrm{~Hz}, 1 \mathrm{H}, \mathrm{Ar}-H), 10.69$ (br s, $1 \mathrm{H}$, $\mathrm{NH}$ ); HRMS (ESI) $m / z$ calcd for $\mathrm{C}_{22} \mathrm{H}_{24} \mathrm{NO}_{6} \mathrm{~S}[\mathrm{M}+\mathrm{H}]^{+} 430.1324$, found 430.1328; Anal. $\left(\mathrm{C}_{22} \mathrm{H}_{23} \mathrm{NO}_{6} \mathrm{~S}\right) \mathrm{C}, \mathrm{H}, \mathrm{N}$.

5.6.3.7. Dimethyl 2-(6-butoxynaphthalene-2-sulfonamido)terephthalate (29g). Purification on $\mathrm{SiO}_{2}$ (EtOAc/hexane 1/3) gave $212 \mathrm{mg}(45 \%)$ of a white solid. Mp 125.5-126.5 ${ }^{\circ} \mathrm{C} ;{ }^{1} \mathrm{H} \mathrm{NMR}\left(300 \mathrm{MHz}, \mathrm{CDCl}_{3}\right) \delta 0.99(\mathrm{t}$, $\left.J=7.4 \mathrm{~Hz}, 3 \mathrm{H}, \mathrm{CH}_{2} \mathrm{CH}_{3}\right), 1.45-1.51\left(\mathrm{~m}, 2 \mathrm{H}, \mathrm{CH}_{2} \mathrm{CH}_{3}\right), 1.77-1.91(\mathrm{~m}, 2 \mathrm{H}$, $\left.\mathrm{OCH}_{2} \mathrm{CH}_{2}\right), 3.87\left(\mathrm{~s}, 3 \mathrm{H}, \mathrm{CH}_{3}\right), 3.93\left(\mathrm{~s}, 3 \mathrm{H}, \mathrm{CH}_{3}\right), 4.07(\mathrm{t}, J=6.5 \mathrm{~Hz}, 2 \mathrm{H}$, $\mathrm{OCH}_{2}$ ), 7.11 (d, $\left.J=2.4 \mathrm{~Hz}, 1 \mathrm{H}, \mathrm{Ar}-H\right), 7.22$ (dd, $J=9.0,2.4 \mathrm{~Hz}, 1 \mathrm{H}, \mathrm{Ar}-\mathrm{H}$ ), 7.62 (dd, $J=8.3,1.5 \mathrm{~Hz}, 1 \mathrm{H}, \mathrm{Ar}-H), 7.72-7.84(\mathrm{~m}, 3 \mathrm{H}, \mathrm{Ar}-\mathrm{H}), 7.93$ (d, $J=8.3 \mathrm{~Hz}, 1 \mathrm{H}, \mathrm{Ar}-H), 8.39(\mathrm{~d}, J=1.5 \mathrm{~Hz}, 1 \mathrm{H}, \mathrm{Ar}-H), 8.41(\mathrm{~d}, J=1.5 \mathrm{~Hz}, 1 \mathrm{H}$, Ar- $H$ ), 10.63 (br s, $1 \mathrm{H}, \mathrm{NH}$ ); ${ }^{13} \mathrm{C}$ NMR (100 MHz, $\mathrm{CDCl}_{3}$ ): $\delta 13.80,19.22$, 31.07, 52.64, 52.74, 67.93, 106.36, 118.89, 119.75, 120.87, 122.84, 123.26, 127.13, 127.94, 129.04, 130.71, 131.19, 133.21, 135.19, 136.82, 140.52,
159.67, 165.56, 167.63; HRMS (ESI) $m / z$ calcd for $\mathrm{C}_{24} \mathrm{H}_{24} \mathrm{NO}_{7} \mathrm{~S}[\mathrm{M}-\mathrm{H}]^{-}$ 470.1273, found 470.1268; Anal. $\left(\mathrm{C}_{24} \mathrm{H}_{25} \mathrm{NO}_{7} \mathrm{~S}\right) \mathrm{C}, \mathrm{H}, \mathrm{N}$.

5.6.3.8. Dimethyl 5-(6-butoxynaphthalene-2-sulfonamido)isophthalate (29h). Purification on $\mathrm{SiO}_{2}$ (EtOAc/hexane 3/5) gave $283 \mathrm{mg}$ (62\%) of a white solid. Mp: $187.0-188.0{ }^{\circ} \mathrm{C} ;{ }^{1} \mathrm{H} \mathrm{NMR}\left(300 \mathrm{MHz}, \mathrm{CDCl}_{3}\right): \delta 0.99$ $\left(\mathrm{t}, J=7.4 \mathrm{~Hz}, 3 \mathrm{H}, \mathrm{CH}_{2} \mathrm{CH}_{3}\right), 1.45-1.54\left(\mathrm{~m}, 2 \mathrm{H}, \mathrm{CH}_{2} \mathrm{CH}_{3}\right), 1.77-1.89(\mathrm{~m}$, $\left.2 \mathrm{H}, \mathrm{OCH}_{2} \mathrm{CH}_{2}\right), 3.91\left(\mathrm{~s}, 6 \mathrm{H}, 2 \times \mathrm{CH}_{3}\right), 3.93\left(\mathrm{~s}, 3 \mathrm{H}, \mathrm{CH}_{3}\right), 4.07(\mathrm{t}$, $\left.J=6.5 \mathrm{~Hz}, 2 \mathrm{H}, \mathrm{OCH}_{2}\right), 7.09(\mathrm{~d}, J=2.4 \mathrm{~Hz}, 1 \mathrm{H}, \mathrm{Ar}-\mathrm{H}), 7.11(\mathrm{br} \mathrm{s}, 1 \mathrm{H}, \mathrm{NH})$, 7.21 (dd, $J=9.0,2.4 \mathrm{~Hz}, 1 \mathrm{H}, \mathrm{Ar}-H), 7.66-7.75$ (m, 2H, Ar-H), 7.77 (d, $J=9.0 \mathrm{~Hz}, 1 \mathrm{H}, \mathrm{Ar}-H), 7.98-8.02(\mathrm{~m}, 2 \mathrm{H}, \mathrm{Ar}-H), 8.32(\mathrm{~d}, J=1.5 \mathrm{~Hz}, 1 \mathrm{H}$, Ar- $H$ ), 8.36 (dd, $J=1.4,1.4 \mathrm{~Hz}, 1 \mathrm{H}, \mathrm{Ar}-H$ ); HRMS (ESI) $m / z$ calcd for $\mathrm{C}_{24} \mathrm{H}_{26} \mathrm{NO}_{7} \mathrm{~S}[\mathrm{M}+\mathrm{H}]^{+}$472.1320, found 472.1433; Anal. $\left(\mathrm{C}_{24} \mathrm{H}_{25} \mathrm{NO}_{7} \mathrm{~S}\right)$ $\mathrm{C}, \mathrm{H}, \mathrm{N}$.

5.6.3.9. Dimethyl 4-(6-butoxynaphthalene-2-sulfonamido)isophthalate (29i). Purification on $\mathrm{SiO}_{2}$ (EtOAc/hexane 3/5) gave $184 \mathrm{mg}(62 \%)$ of a white solid. Mp: $75.0-76.0{ }^{\circ} \mathrm{C} ;{ }^{1} \mathrm{H}$ NMR $\left(300 \mathrm{MHz}, \mathrm{CDCl}_{3}\right): \delta 0.99(\mathrm{t}$, $\left.J=7.4 \mathrm{~Hz}, 3 \mathrm{H}, \mathrm{CH}_{2} \mathrm{CH}_{3}\right), 1.46-1.57\left(\mathrm{~m}, 2 \mathrm{H}, \mathrm{CH}_{2} \mathrm{CH}_{3}\right), 1.77-1.88(\mathrm{~m}, 2 \mathrm{H}$, $\left.\mathrm{OCH}_{2} \mathrm{CH}_{2}\right), 3.86\left(\mathrm{~s}, 3 \mathrm{H}, \mathrm{CH}_{3}\right), 3.92\left(\mathrm{~s}, 3 \mathrm{H}, \mathrm{CH}_{3}\right), 4.08(\mathrm{t}, J=6.5 \mathrm{~Hz}, 2 \mathrm{H}$, $\left.\mathrm{OCH}_{2}\right), 7.10(\mathrm{~d}, J=2.4 \mathrm{~Hz}, 1 \mathrm{H}, \mathrm{Ar}-\mathrm{H}), 7.23$ (dd, $\left.J=9.0,2.4 \mathrm{~Hz}, 1 \mathrm{H}, \mathrm{Ar}-\mathrm{H}\right)$, $7.71-7.80(\mathrm{~m}, 3 \mathrm{H}, \mathrm{Ar}-H), 7.82(\mathrm{~d}, J=9.0 \mathrm{~Hz}, 1 \mathrm{H}, \mathrm{Ar}-H), 8.05$ (dd, $J=8.7$, $2.1 \mathrm{~Hz}, 1 \mathrm{H}, \mathrm{Ar}-\mathrm{H}), 8.41(\mathrm{~d}, J=1.5 \mathrm{~Hz}, 1 \mathrm{H}, \mathrm{Ar}-H), 8.58(\mathrm{~d}, J=2.1 \mathrm{~Hz}, 1 \mathrm{H}$, Ar- $H$ ), 11.09 (br s, $1 \mathrm{H}, \mathrm{NH}$ ); HRMS (ESI) $\mathrm{m} / z$ calcd for $\mathrm{C}_{24} \mathrm{H}_{25} \mathrm{NO}_{7} \mathrm{SNa}$ $[\mathrm{M}+\mathrm{Na}]^{+}$494.1249, found 494.1269; Anal. $\left(\mathrm{C}_{24} \mathrm{H}_{25} \mathrm{NO}_{7} \mathrm{~S}\right) \mathrm{C}, \mathrm{H}, \mathrm{N}$.

5.6.3.10. Methyl 1-(6-(4-cyano-2-fluorobenzyloxy)naphthalen-2-ylsulfonyl)piperidine-4-carboxylate (30a). Purification on $\mathrm{SiO}_{2}$ (EtOAc/ hexane 1/1) gave $175 \mathrm{mg}(66 \%)$ of a white solid. Mp: $173.5-175.0^{\circ} \mathrm{C}$; ${ }^{1} \mathrm{H}$ NMR (300 MHz, $\mathrm{CDCl}_{3}$ ): $\delta$ 1.75-1.90 (m, 2H, piperidyl- $H$ ), 1.92-2.03 (m, $2 \mathrm{H}$, piperidyl- $H$ ), 2.25 (sym m, $1 \mathrm{H}$, piperidyl- $H$ ), 2.56 $(\mathrm{td}, J=11.7,2.9 \mathrm{~Hz}, 2 \mathrm{H}$, piperidyl- $H), 3.64\left(\mathrm{~s}, 3 \mathrm{H}, \mathrm{CH}_{3}\right), 3.69(\mathrm{dt}$, $J=12.0,3.9 \mathrm{~Hz}, 2 \mathrm{H}$, piperidyl $-H), 5.34\left(\mathrm{~s}, 2 \mathrm{H}, \mathrm{OCH}_{2}\right), 7.27(\mathrm{~d}, J=2.7 \mathrm{~Hz}$, $1 \mathrm{H}, \operatorname{Ar}-H), 7.35$ (dd, $J=9.0,2.7 \mathrm{~Hz}, 1 \mathrm{H}, \operatorname{Ar}-H), 7.44(\mathrm{dd}, J=9.3,1.5 \mathrm{~Hz}$, $1 \mathrm{H}, \mathrm{Ar}-H), 7.53(\mathrm{dd}, J=7.9,1.0 \mathrm{~Hz}, 1 \mathrm{H}, \mathrm{Ar}-H), 7.69-7.77(\mathrm{~m}, 2 \mathrm{H}, \mathrm{Ar}-H)$, $7.85(\mathrm{~d}, J=9.0 \mathrm{~Hz}, 1 \mathrm{H}, \mathrm{Ar}-H), 7.91$ (d, $J=9.3 \mathrm{~Hz}, 1 \mathrm{H}, \mathrm{Ar}-H), 8.26$ (d, $J=1.0 \mathrm{~Hz}, 1 \mathrm{H}$, Ar- $H$ ); HRMS (ESI) $m / z$ calcd for $\mathrm{C}_{25} \mathrm{H}_{24} \mathrm{FN}_{2} \mathrm{O}_{5} \mathrm{~S}$ $[\mathrm{M}+\mathrm{H}]^{+}$483.1390, found 483.1370; Anal. $\left(\mathrm{C}_{25} \mathrm{H}_{23} \mathrm{FN}_{2} \mathrm{O}_{5} \mathrm{~S}\right) \mathrm{C}, \mathrm{H}, \mathrm{N}$.

5.6.3.11. (1R,2S)-ethyl 2-(6-(4-cyano-2-fluorobenzyloxy)naphthalene-2-sulfonamido)cyclohexanecarboxylate (30b). Purification on $\mathrm{SiO}_{2}$ (EtOAc/hexane 3/5) gave $279 \mathrm{mg}$ (71\%) of a white solid. Mp: 141.0-143.5 ${ }^{\circ} \mathrm{C} ;[\alpha]_{\mathrm{D}}{ }^{20}$ : $-6.6\left(\right.$ c $\left.0.192, \mathrm{CH}_{2} \mathrm{Cl}_{2}\right) ;{ }^{1} \mathrm{H}$ NMR $(300 \mathrm{MHz}$, $\left.\mathrm{CDCl}_{3}\right): \delta 1.12\left(\mathrm{t}, J=7.1 \mathrm{~Hz}, 3 \mathrm{H}, \mathrm{OCH}_{2} \mathrm{CH}_{3}\right), 1.18-1.69(\mathrm{~m}, 6 \mathrm{H}$, cyclohexyl- $H$ ), 1.71-2.02 (m, 2H, cyclohexyl- $H), 2.63(\mathrm{q}, 1 \mathrm{H}$, $J=4.9 \mathrm{~Hz}$, cyclohexyl- $H$ ), 3.49 (sym m, $1 \mathrm{H}$, cyclohexyl- $H$ ), 3.84-4.14 $\left(\mathrm{m}, 2 \mathrm{H}, \mathrm{OCH}_{2} \mathrm{CH}_{3}\right), 5.32\left(\mathrm{~s}, 2 \mathrm{H}, \mathrm{OCH}_{2}\right), 5.65(\mathrm{~d}, J=8.9 \mathrm{~Hz}, 1 \mathrm{H}, \mathrm{NH})$, $7.25(\mathrm{~d}, J=2.4 \mathrm{~Hz}, 1 \mathrm{H}, \mathrm{Ar}-H), 7.33$ (dd, $J=8.7,2.4 \mathrm{~Hz}, 1 \mathrm{H}, \mathrm{Ar}-H), 7.43$ (dd, $J=9.2,1.4 \mathrm{~Hz}, 1 \mathrm{H}, \mathrm{Ar}-H), 7.52(\mathrm{dd}, J=7.9,1.0 \mathrm{~Hz}, 1 \mathrm{H}, \mathrm{Ar}-H)$, 7.70-7.85 (m, 3H, Ar- H), $7.90(\mathrm{~d}, J=9.2 \mathrm{~Hz}, 1 \mathrm{H}, \mathrm{Ar}-\mathrm{H}), 8.36$ (d, $J=1.0 \mathrm{~Hz}, 1 \mathrm{H}$, Ar- $H$ ); HRMS (ESI) $\mathrm{m} / z$ calcd for $\mathrm{C}_{27} \mathrm{H}_{28} \mathrm{FN}_{2} \mathrm{O}_{5} \mathrm{~S}$ $[\mathrm{M}+\mathrm{H}]^{+}$511.1703, found 511.1699; Anal. $\left(\mathrm{C}_{27} \mathrm{H}_{27} \mathrm{FN}_{2} \mathrm{O}_{5} \mathrm{~S}\right) \mathrm{C}, \mathrm{H}, \mathrm{N}$.

5.6.3.12. (1R,2R)-ethyl 2-(6-(4-cyano-2-fluorobenzyloxy)naphthalene-2-sulfonamido)cyclohexanecarboxylate (30c). Purification on $\mathrm{SiO}_{2}$ (EtOAc/hexane 3/5) gave $318 \mathrm{mg}(81 \%)$ of a white solid. Mp: 145.0-147.5 ${ }^{\circ} \mathrm{C} ;[\alpha]_{\mathrm{D}}{ }^{20}:+7.52\left(\mathrm{c} 0.269, \mathrm{CH}_{2} \mathrm{Cl}_{2}\right) ;{ }^{1} \mathrm{H}$ NMR $(300 \mathrm{MHz}$, $\left.\mathrm{CDCl}_{3}\right): \delta 1.04\left(\mathrm{t}, J=7.1 \mathrm{~Hz}, 3 \mathrm{H}, \mathrm{OCH}_{2} \mathrm{CH}_{3}\right), 1.10-1.33(\mathrm{~m}, 3 \mathrm{H}$, cyclohexyl- $H$ ), 1.39-1.71 (m, 3H, cyclohexyl-H), 1.81-1.93 (m, $1 \mathrm{H}$, cyclohexyl- $H$ ), 2.01-2.12 (m, $1 \mathrm{H}$, cyclohexyl- $H), 2.23(\mathrm{td}, J=11.2$, $3.8 \mathrm{~Hz}, 1 \mathrm{H}$, cyclohexyl-H), 3.35-3.49 (m, 1H, cyclohexyl- $H)$, 3.64-3.91 (m, $\left.2 \mathrm{H}, \mathrm{OCH}_{2} \mathrm{CH}_{3}\right), 5.32\left(\mathrm{~s}, 2 \mathrm{H}, \mathrm{OCH}_{2}\right), 4.72(\mathrm{~d}, J=7.8 \mathrm{~Hz}$, $1 \mathrm{H}, \mathrm{NH}), 7.25(\mathrm{~d}, J=2.4 \mathrm{~Hz}, 1 \mathrm{H}, \mathrm{Ar}-H), 7.33(\mathrm{dd}, J=8.8,2.4 \mathrm{~Hz}, 1 \mathrm{H}$, $\operatorname{Ar}-H), 7.43(\mathrm{dd}, J=9.3,1.5 \mathrm{~Hz}, 1 \mathrm{H}, \mathrm{Ar}-H), 7.52(\mathrm{dd}, J=7.9,1.0 \mathrm{~Hz}, 1 \mathrm{H}$, Ar- $H$ ), 7.70-7.86 (m, 3H, Ar- H), $7.90(\mathrm{~d}, J=9.3 \mathrm{~Hz}, 1 \mathrm{H}, \mathrm{Ar}-\mathrm{H}), 8.36$ (d, 
$J=1.0 \mathrm{~Hz}, 1 \mathrm{H}, \mathrm{Ar}-H) ;{ }^{13} \mathrm{C}$ NMR (100 MHz, $\left.\mathrm{CDCl}_{3}\right): \delta$ 13.90, 24.03, 24.36, 28.49, 33.77, 49.87, 54.31, 60.60, 63.02 and 63.07 (1C, $\left.{ }^{3} J_{\mathrm{F}, \mathrm{C}}=4.4 \mathrm{~Hz}\right), 107.07,113.27$ and $113.36\left(1 \mathrm{C},{ }^{3} \mathrm{~J}_{\mathrm{F}, \mathrm{C}}=9.5 \mathrm{~Hz}\right), 117.32$ and $117.35\left(1 \mathrm{C},{ }^{4} J_{\mathrm{F}, \mathrm{C}}=2.8 \mathrm{~Hz}\right), 118.94$ and $119.18\left(1 \mathrm{C},{ }^{2} \mathrm{~J}_{\mathrm{F}, \mathrm{C}}=25.7 \mathrm{~Hz}\right)$, $120.15,123.42,127.81,127.95,127.98,128.47$ and 128.51 (1C, $\left.{ }^{3} J_{\mathrm{F}, \mathrm{C}}=5.1 \mathrm{~Hz}\right), 129.58$ and $129.72\left(1 \mathrm{C},{ }^{2} J_{\mathrm{F}, \mathrm{C}}=15.4 \mathrm{~Hz}\right), 130.04$ and $130.08\left(1 \mathrm{C},{ }^{4} \mathrm{~J}_{\mathrm{F}, \mathrm{C}}=3.7 \mathrm{~Hz}\right), 131.13,136.11,136.20,157.98,158.23$ and $160.72\left(1 \mathrm{C},{ }^{1} J_{\mathrm{F}, \mathrm{C}}=250.8 \mathrm{~Hz}\right), 173.45$; HRMS (ESI) $\mathrm{m} / \mathrm{z}$ calcd for $\mathrm{C}_{27} \mathrm{H}_{28} \mathrm{FN}_{2} \mathrm{O}_{5} \mathrm{~S}[\mathrm{M}+\mathrm{H}]^{+}$511.1703, found 511.1698; Anal. $\left(\mathrm{C}_{27} \mathrm{H}_{27} \mathrm{FN}_{2} \mathrm{O}_{5} \mathrm{~S}\right) \mathrm{C}, \mathrm{H}, \mathrm{N}$.

5.6.3.13. Diethyl 4-(6-(4-cyano-2-fluorobenzyloxy)naphthalene-2-sulfonamido)cyclohexane-1,3-dicarboxylate, racemate (30d). Purification on $\mathrm{SiO}_{2}$ (EtOAc/hexane 3/5) gave $284 \mathrm{mg}$ (49\%) of a white solid. Mp: 152.0-153.0 ${ }^{\circ} \mathrm{C} ;[\alpha]_{\mathrm{D}}{ }^{20}:+0.6\left(\right.$ c $\left.0.157, \mathrm{CH}_{2} \mathrm{Cl}_{2}\right) ;{ }^{1} \mathrm{H}$ NMR $(300 \mathrm{MHz}$, $\left.\mathrm{CDCl}_{3}\right): \delta 0.95\left(\mathrm{t}, J=7.1 \mathrm{~Hz}, 3 \mathrm{H}, \mathrm{OCH}_{2} \mathrm{CH}_{3}\right), 1.25(\mathrm{t}, J=7.1 \mathrm{~Hz}, 3 \mathrm{H}$, $\left.\mathrm{OCH}_{2} \mathrm{CH}_{3}\right), 1.34-1.47(\mathrm{~m}, 1 \mathrm{H}$, cyclohexyl- $\mathrm{H}), 1.70-1.92(\mathrm{~m}, 3 \mathrm{H}$, cyclohexyl- $H), 1.94-2.04(\mathrm{~m}, 1 \mathrm{H}$, cyclohexyl- $H), 2.08-2.36(\mathrm{~m}, 2 \mathrm{H}$, cyclohexyl- $H), 2.48(\mathrm{dt}, J=12.4,3.8 \mathrm{~Hz}, 1 \mathrm{H}$, cyclohexyl- $H), 3.58(\mathrm{sym} \mathrm{m}, 1 \mathrm{H}$, cyclohexyl- $\mathrm{H}), 3.69-3.95\left(\mathrm{~m}, 2 \mathrm{H}, \mathrm{OCH}_{2} \mathrm{CH}_{3}\right), 4.13(\mathrm{q}, J=7.1 \mathrm{~Hz}, 1 \mathrm{H}$, $\left.\mathrm{OCH}_{2} \mathrm{CH}_{3}\right), 5.22(\mathrm{~d}, J=6.1 \mathrm{~Hz}, 1 \mathrm{H}, \mathrm{NH}), 5.33\left(\mathrm{~s}, 2 \mathrm{H}, \mathrm{OCH}_{2}\right), 7.25$ (d, $J=2.4 \mathrm{~Hz}, 1 \mathrm{H}, \mathrm{Ar}-H), 7.34$ (dd, $J=9.0,2.4 \mathrm{~Hz}, 1 \mathrm{H}, \mathrm{Ar}-H), 7.44$ (dd, $J=9.3,1.5 \mathrm{~Hz}, 1 \mathrm{H}, \mathrm{Ar}-H), 7.52(\mathrm{dd}, J=8.1,1.0 \mathrm{~Hz}, 1 \mathrm{H}, \mathrm{Ar}-H), 7.70-7.86$ $(\mathrm{m}, 3 \mathrm{H}, \mathrm{Ar}-\mathrm{H}), 7.91(\mathrm{~d}, J=9.3 \mathrm{~Hz}, 1 \mathrm{H}, \mathrm{Ar}-H), 8.35(\mathrm{~d}, J=1.0 \mathrm{~Hz}, 1 \mathrm{H}, \mathrm{Ar}-$ $H$ ); HRMS (ESI) $m / z$ calcd for $\mathrm{C}_{30} \mathrm{H}_{32} \mathrm{FN}_{2} \mathrm{O}_{7} \mathrm{~S}[\mathrm{M}+\mathrm{H}]^{+} 583.1914$, found 583.1906; Anal. $\left(\mathrm{C}_{30} \mathrm{H}_{31} \mathrm{FN}_{2} \mathrm{O}_{7} \mathrm{~S}\right) \mathrm{C}, \mathrm{H}, \mathrm{N}$.

5.6.3.14. Methyl 2-(4-(6-(4-cyano-2-fluorobenzyloxy)naphthalene2-sulfonamido)phenyl)acetate (30e). Purification on $\mathrm{SiO}_{2}$ (EtOAc/ hexane 1/1) gave $263 \mathrm{mg}(67 \%)$ of a pale brown solid. Mp: 184.5-186.0 ${ }^{\circ} \mathrm{C} ;{ }^{1} \mathrm{H}$ NMR (300 MHz, DMSO-d $\left.d_{6}\right): \delta 3.52(\mathrm{~s}, 2 \mathrm{H}$, $\left.\mathrm{CH}_{2} \mathrm{COO}\right), 3.55\left(\mathrm{~s}, 3 \mathrm{H}, \mathrm{CH}_{3}\right), 5.39\left(\mathrm{~s}, 2 \mathrm{H}, \mathrm{OCH}_{2}\right), 7.02-7.10(\mathrm{~m}, 4 \mathrm{H}, \mathrm{Ar}-$ $H), 7.38(\mathrm{dd}, J=9.0,2.4 \mathrm{~Hz}, 1 \mathrm{H}, \mathrm{Ar}-H), 7.57(\mathrm{~d}, J=2.4 \mathrm{~Hz}, 1 \mathrm{H}, \mathrm{Ar}-H)$, 7.73 (dd, $J=8.7,1.8 \mathrm{~Hz}, 1 \mathrm{H}$, Ar- $H$ ), 7.76-7.85 (m, 2H, Ar- $H$ ), 7.90-7.99 (m, 2H, Ar-H), 8.07 (d, $J=9.0 \mathrm{~Hz}, 1 \mathrm{H}, \operatorname{Ar}-H), 8.36$ (d, $J=1.8 \mathrm{~Hz}, 1 \mathrm{H}, \mathrm{Ar}-H$ ), 10.28 (br s, $1 \mathrm{H}, \mathrm{NH}$ ); HRMS (ESI) $m / z$ calcd for $\mathrm{C}_{27} \mathrm{H}_{22} \mathrm{FN}_{2} \mathrm{O}_{5} \mathrm{~S}[\mathrm{M}+\mathrm{H}]^{+}$505.1233, found 505.1230; Anal. $\left(\mathrm{C}_{27} \mathrm{H}_{21} \mathrm{FN}_{2} \mathrm{O}_{5} \mathrm{~S}\right) \mathrm{C}, \mathrm{H}, \mathrm{N}$.

5.6.3.15. Methyl 2-(6-(4-cyano-2-fluorobenzyloxy)naphthalene-2sulfonamido)-5-hydroxybenzoate (30f). Purification on $\mathrm{SiO}_{2}$ (EtOAc/ hexane 3/5) gave $185 \mathrm{mg}$ (69\%) of a yellowish solid. Mp: 159.5-162.5 ${ }^{\circ} \mathrm{C} ;{ }^{1} \mathrm{H}$ NMR (300 MHz, DMSO-d $\left.d_{6}\right): \delta 3.64\left(\mathrm{~s}, 3 \mathrm{H}, \mathrm{CH}_{3}\right)$, $5.44\left(\mathrm{~s}, 2 \mathrm{H}, \mathrm{OCH}_{2}\right), 6.64(\mathrm{~d}, J=9.0 \mathrm{~Hz}, 1 \mathrm{H}, \mathrm{Ar}-H), 6.72(\mathrm{~s}, 1 \mathrm{H}, \mathrm{OH})$, 6.85 (dd, $J=9.0,2.9 \mathrm{~Hz}, 1 \mathrm{H}, \mathrm{Ar}-H), 7.23$ (d, $J=2.9 \mathrm{~Hz}, 1 \mathrm{H}, \mathrm{Ar}-H), 7.45$ $(\mathrm{dd}, J=9.0,2.5 \mathrm{~Hz}, 1 \mathrm{H}, \mathrm{Ar}-H), 7.69(\mathrm{~d}, J=2.5 \mathrm{~Hz}, 1 \mathrm{H}, \mathrm{Ar}-H), 7.76-7.89$ (m, 3H, Ar- $H$ ), 7.95 (dd, $J=9.9,1.5 \mathrm{~Hz}, 1 \mathrm{H}, \mathrm{Ar}-H), 8.08(\mathrm{~d}, J=9.0 \mathrm{~Hz}$, $1 \mathrm{H}, \operatorname{Ar}-H), 8.16$ (d, $J=9.0 \mathrm{~Hz}, 1 \mathrm{H}, \mathrm{Ar}-H), 8.45(\mathrm{~d}, J=1.7 \mathrm{~Hz}, 1 \mathrm{H}, \mathrm{Ar}-H)$, 10.92 (br s, $1 \mathrm{H}, \mathrm{NH}$ ); HRMS (ESI) $\mathrm{m} / z$ calcd for $\mathrm{C}_{26} \mathrm{H}_{20} \mathrm{FN}_{2} \mathrm{O}_{6} \mathrm{~S}$ $[\mathrm{M}+\mathrm{H}]^{+}$507.1026, found 507.1030; Anal. $\left(\mathrm{C}_{26} \mathrm{H}_{19} \mathrm{FN}_{2} \mathrm{O}_{6} \mathrm{~S}\right) \mathrm{C}, \mathrm{H}, \mathrm{N}$.

5.6.3.16. Dimethyl 2-(6-(4-cyano-2-fluorobenzyloxy)naphthalene-2sulfonamido)terephthalate (30g). Purification on $\mathrm{SiO}_{2}$ (EtOAc/ hexane 3/5) gave $141 \mathrm{mg}(37 \%)$ of a white solid. Mp: 180.5-183.0 ${ }^{\circ} \mathrm{C} ;{ }^{1} \mathrm{H}$ NMR $\left(300 \mathrm{MHz}, \mathrm{CDCl}_{3}\right): \delta 3.89\left(\mathrm{~s}, 3 \mathrm{H}, \mathrm{CH}_{3}\right), 3.93$ $\left(\mathrm{s}, 3 \mathrm{H}, \mathrm{CH}_{3}\right), 5.29\left(\mathrm{~s}, 2 \mathrm{H}, \mathrm{OCH}_{2}\right), 7.19(\mathrm{~d}, J=2.4 \mathrm{~Hz}, 1 \mathrm{H}, \mathrm{Ar}-\mathrm{H}), 7.31(\mathrm{dd}$, $J=9.0,2.4 \mathrm{~Hz}, 1 \mathrm{H}, \mathrm{Ar}-H), 7.42(\mathrm{dd}, J=9.3,1.5 \mathrm{~Hz}, 1 \mathrm{H}, \mathrm{Ar}-H), 7.51$ (dd, $J=7.9,1.3 \mathrm{~Hz}, 1 \mathrm{H}, \mathrm{Ar}-\mathrm{H}), 7.63(\mathrm{dd} J=8.4,1.5 \mathrm{~Hz}, 1 \mathrm{H}, \mathrm{Ar}-H), 7.67-7.85$ $(\mathrm{m}, 3 \mathrm{H}, \mathrm{Ar}-H), 7.88(\mathrm{~d}, J=9.3 \mathrm{~Hz}, 1 \mathrm{H}, \mathrm{Ar}-H), 7.94(\mathrm{~d}, J=8.4 \mathrm{~Hz}, 1 \mathrm{H}$, $\operatorname{Ar}-H$ ), 8.39 (d, $J=1.3 \mathrm{~Hz}, 1 \mathrm{H}, \operatorname{Ar}-H), 8.45$ (d, $J=1.5 \mathrm{~Hz}, 1 \mathrm{H}, \operatorname{Ar}-H$ ), 10.67 (br s, $1 \mathrm{H}, \mathrm{NH}$ ); HRMS (ESI) $m / z$ calcd for $\mathrm{C}_{28} \mathrm{H}_{22} \mathrm{FN}_{2} \mathrm{O}_{7} \mathrm{~S}$ $[\mathrm{M}+\mathrm{H}]^{+}$549.1132, found 549.1136; Anal. $\left(\mathrm{C}_{28} \mathrm{H}_{21} \mathrm{FN}_{2} \mathrm{O}_{7} \mathrm{~S}\right) \mathrm{C}, \mathrm{H}, \mathrm{N}$.

5.6.3.17. Dimethyl 5-(6-(4-cyano-2-fluorobenzyloxy)naphthalene-2sulfonamido)isophthalate (30h). Purification on $\mathrm{SiO}_{2}$ (EtOAc/hexane
3/5) gave $399 \mathrm{mg}(64 \%)$ of a white solid. Mp: 206.0-209.0 ${ }^{\circ} \mathrm{C} ;{ }^{1} \mathrm{H}$ NMR (300 MHz, $\left.\mathrm{CDCl}_{3}\right): \delta 3.91\left(\mathrm{~s}, 6 \mathrm{H}, 2 \times \mathrm{CH}_{3}\right), 5.30\left(\mathrm{~s}, 2 \mathrm{H}, \mathrm{OCH}_{2}\right)$, 6.90 (br s, $1 \mathrm{H}, \mathrm{NH}$ ), 7.20 (d, $J=2.4 \mathrm{~Hz}, 1 \mathrm{H}, \mathrm{Ar}-H$ ), 7.31 (dd, $J=9.0$, $2.4 \mathrm{~Hz}, 1 \mathrm{H}, \mathrm{Ar}-H), 7.43$ (dd, $J=9.3,1.4 \mathrm{~Hz}, 1 \mathrm{H}, \mathrm{Ar}-H), 7.51$ (dd, $J=7.8$, $1.3 \mathrm{~Hz}, 1 \mathrm{H}, \mathrm{Ar}-H), 7.65-7.77(\mathrm{~m}, 3 \mathrm{H}, \mathrm{Ar}-H), 7.85(\mathrm{~d}, J=9.3 \mathrm{~Hz}, 1 \mathrm{H}, \mathrm{Ar}-$ $H$ ), 7.97-8.00 (m, 2H, Ar-H), 8.35 (d, $J=1.3 \mathrm{~Hz}, 1 \mathrm{H}, \mathrm{Ar}-H), 8.36$ (dd, $J=1.4,1.4 \mathrm{~Hz}, 1 \mathrm{H}, \mathrm{Ar}-\mathrm{H}$ ); HRMS (ESI) $m / z$ calcd for $\mathrm{C}_{28} \mathrm{H}_{20} \mathrm{FN}_{2} \mathrm{O}_{7} \mathrm{~S}$ $[\mathrm{M}-\mathrm{H}]^{-}$547.0975, found 547.0974; Anal. $\left(\mathrm{C}_{28} \mathrm{H}_{21} \mathrm{FN}_{2} \mathrm{O}_{7} \mathrm{~S}\right) \mathrm{C}, \mathrm{H}, \mathrm{N}$.

5.6.3.18. Dimethyl 4-(6-(4-cyano-2-fluorobenzyloxy)naphthalene-2sulfonamido)isophthalate (30i). Purification on $\mathrm{SiO}_{2}$ (EtOAc/hexane 3/5) gave $284 \mathrm{mg}(52 \%)$ of a white solid. Mp: $169.0-170.0{ }^{\circ} \mathrm{C} ;{ }^{1} \mathrm{H}$ $\operatorname{NMR}\left(300 \mathrm{MHz}, \mathrm{CDCl}_{3}\right): \delta 3.87\left(\mathrm{~s}, 3 \mathrm{H}, \mathrm{CH}_{3}\right), 3.93\left(\mathrm{~s}, 3 \mathrm{H}, \mathrm{CH}_{3}\right), 5.30(\mathrm{~s}$, $\left.2 \mathrm{H}, \mathrm{OCH}_{2}\right), 7.20(\mathrm{~d}, J=2.4 \mathrm{~Hz}, 1 \mathrm{H}, \mathrm{Ar}-H), 7.33(\mathrm{dd}, J=9.0,2.4 \mathrm{~Hz}, 1 \mathrm{H}$, Ar- $H$ ), $7.42(\mathrm{dd}, J=9.3,1.3 \mathrm{~Hz}, 1 \mathrm{H}, \mathrm{Ar}-H), 7.51(\mathrm{dd}, J=7.8,1.3 \mathrm{~Hz}, 1 \mathrm{H}$, Ar- $H$ ), 7.67-7.85 (m, 4H, Ar- $H$ ), 7.89 (d, $J=9.0 \mathrm{~Hz}, 1 \mathrm{H}, \mathrm{Ar}-H), 8.06$ (dd, $J=8.7,2.1 \mathrm{~Hz}, 1 \mathrm{H}, \mathrm{Ar}-H), 8.45$ (d, $J=1.5 \mathrm{~Hz}, 1 \mathrm{H}, \mathrm{Ar}-H), 8.59$ (d, $J=2.1 \mathrm{~Hz}, 1 \mathrm{H}, \mathrm{Ar}-\mathrm{H}), 11.10$ (br s, $1 \mathrm{H}, \mathrm{NH}) ;{ }^{13} \mathrm{C} \mathrm{NMR}\left(100 \mathrm{MHz}, \mathrm{CDCl}_{3}\right.$ ): $\delta 52.27,52.76,63.06$ and $63.10\left(1 \mathrm{C},{ }^{3} J_{\mathrm{F}, \mathrm{C}}=4.4 \mathrm{~Hz}\right), 107.07,113.35$ and $113.44\left(1 \mathrm{C},{ }^{3} \mathrm{~F}_{\mathrm{F}, \mathrm{C}}=9.4 \mathrm{~Hz}\right), 114.69,117.28$ and $117.31(1 \mathrm{C}$, $\left.{ }^{4} J_{\mathrm{F}, \mathrm{C}}=2.8 \mathrm{~Hz}\right), 117.43,118.97$ and $119.21\left(1 \mathrm{C},{ }^{2} J_{\mathrm{F}, \mathrm{C}}=24.2 \mathrm{~Hz}\right), 120.50$, $123.01,124.12,127.65,128.41,128.48$ and $128.52\left(1 \mathrm{C},{ }^{3} J_{\mathrm{F}, \mathrm{C}}=5.1 \mathrm{~Hz}\right)$, 128.86, 129.41 and $129.55\left(1 \mathrm{C},{ }^{2} J_{\mathrm{F}, \mathrm{C}}=14.8 \mathrm{~Hz}\right), 130.00$ and 130.04 $\left(1 \mathrm{C},{ }^{4} J_{\mathrm{F}, \mathrm{C}}=3.7 \mathrm{~Hz}\right), 131.27,133.14,134.10,135.35,136.59,144.21$, 158.22 and $160.71\left(1 \mathrm{C},{ }^{1} J_{\mathrm{F}, \mathrm{C}}=250.6 \mathrm{~Hz}\right), 158.38,165.54,167.89$; HRMS (ESI) $m / z$ calcd for $\mathrm{C}_{28} \mathrm{H}_{20} \mathrm{FN}_{2} \mathrm{O}_{7} \mathrm{~S}[\mathrm{M}-\mathrm{H}]^{-} 547.0975$, found 547.0968; Anal. $\left(\mathrm{C}_{28} \mathrm{H}_{21} \mathrm{FN}_{2} \mathrm{O}_{7} \mathrm{~S}\right) \mathrm{C}, \mathrm{H}$, N.Step 2. Alkaline hydrolysis

Compounds 31a-i were prepared using $1 \mathrm{M} \mathrm{NaOH}$ as a base, while compounds 32a-i were prepared using $2 \mathrm{M} \mathrm{LiOH}$ as a base. To a stirred solution of the protected 6-substituted naphthalene-2sulfonamides $29 \mathbf{a}-\mathbf{i}, 30 \mathbf{a}-\mathbf{i}(0.25 \mathrm{mmol})$ in dioxane $(2 \mathrm{~mL})$, the appropriate base $(1.5 \mathrm{ml} 1 \mathrm{M} \mathrm{NaOH}$, or $0.75 \mathrm{~mL} 2 \mathrm{M} \mathrm{LiOH})$ was added, and the reaction mixture stirred until the starting material had completely reacted (monitored by TLC). Dioxane was then evaporated under reduced pressure, the residue diluted with $\mathrm{H}_{2} \mathrm{O}$ $(10 \mathrm{~mL})$, and washed with EtOAc $(2 \times 10 \mathrm{~mL})$. The aqueous phase was acidified to $\mathrm{pH} 2$ using $1 \mathrm{M} \mathrm{HCl}$, and extracted with EtOAc $(3 \times 10 \mathrm{~mL})$. The combined organic extracts were washed with brine, then dried over $\mathrm{Na}_{2} \mathrm{SO}_{4}$, filtered, and evaporated to dryness to provide pure compounds $31 \mathbf{a}-\mathbf{i}$, and crude products $\mathbf{3 2} \mathbf{a}-\mathbf{i}$ that were purified by column chromatography $\left(\mathrm{CH}_{2} \mathrm{Cl}_{2} / \mathrm{MeOH} /\right.$ AcOH 9/1/0.1) to yield pure compounds.

5.6.3.19. 1-(6-Butoxynaphthalen-2-ylsulfonyl)piperidine-4-carboxylic acid (31a). White solid (121 mg, 92\%); mp: $178.0-180.0{ }^{\circ} \mathrm{C} ;{ }^{1} \mathrm{H}$ NMR (300 MHz, DMSO- $\left.d_{6}\right): \delta 0.96\left(\mathrm{t}, J=7.4 \mathrm{~Hz}, 3 \mathrm{H}, \mathrm{CH}_{2} \mathrm{CH}_{3}\right), 1.41-1.65$ (m, $4 \mathrm{H}, \mathrm{CH}_{2} \mathrm{CH}_{3}$ and piperidyl- $\mathrm{H}$ ), $1.70-1.94\left(\mathrm{~m}, 4 \mathrm{H}, \mathrm{OCH}_{2} \mathrm{CH}_{2}\right.$ and piperidyl- $H$ ), 2.24 (sym m, $1 \mathrm{H}$, piperidyl $-H$ ), 2.45 (td, $J=11.1,1.8 \mathrm{~Hz}$, $2 \mathrm{H}$, piperidyl- $H), 3.52(\mathrm{dt}, J=11.7,3.9 \mathrm{~Hz}, 2 \mathrm{H}$, piperidyl $H), 4.14(\mathrm{t}$, $J=6.5 \mathrm{~Hz}, 2 \mathrm{H}, \mathrm{OCH}_{2}$ ), 7.31 (dd, $\left.J=9.0,2.4 \mathrm{~Hz}, 1 \mathrm{H}, \mathrm{Naph}-H\right), 7.47$ (d, $J=2.4 \mathrm{~Hz}, 1 \mathrm{H}, \mathrm{Naph}-H), 7.68$ (dd, $J=8.7,1.6 \mathrm{~Hz}, 1 \mathrm{H}$, Naph- $H$ ), 8.00 (d, $J=8.7 \mathrm{~Hz}, 1 \mathrm{H}$, Naph-H), 8.09 (d, $J=9.0 \mathrm{~Hz}, 1 \mathrm{H}$, Naph- $H), 8.32(\mathrm{~d}$, $J=1.6 \mathrm{~Hz}, 1 \mathrm{H}, \mathrm{Naph}-H$ ), 12.24 (br s, $1 \mathrm{H}, \mathrm{COOH}$ ); HRMS (ESI) $\mathrm{m} / z$ calcd for $\mathrm{C}_{20} \mathrm{H}_{24} \mathrm{NO}_{5} \mathrm{~S}[\mathrm{M}-\mathrm{H}]^{-}$390.1375, found 390.1389; Anal. $\left(\mathrm{C}_{20} \mathrm{H}_{25} \mathrm{NO}_{5} \mathrm{~S}\right) \mathrm{C}, \mathrm{H}, \mathrm{N}$.

5.6.3.20. (1R,2S)-2-(6-butoxynaphthalene-2-sulfonamido)cyclohexanecarboxylic acid (31b). White solid (117 mg, 89\%); mp: 175.0-176.0 ${ }^{\circ} \mathrm{C} ;[\alpha]_{\mathrm{D}}{ }^{20}:+9.3$ (c 0.161, DMSO); ${ }^{1} \mathrm{H}$ NMR $(300 \mathrm{MHz}$, DMSO-d $\left.d_{6}\right): \delta 0.96\left(\mathrm{t}, J=7.4 \mathrm{~Hz}, 3 \mathrm{H}, \mathrm{CH}_{2} \mathrm{CH}_{3}\right), 1.01-1.26(\mathrm{~m}, 4 \mathrm{H}$, cyclohexyl- $H$ ), $1.33-1.57\left(\mathrm{~m}, 6 \mathrm{H}, \mathrm{CH}_{2} \mathrm{CH}_{3}\right.$ and cyclohexyl- $\left.H\right)$, $1.68-1.84\left(\mathrm{~m}, 3 \mathrm{H}, \mathrm{OCH}_{2} \mathrm{CH}_{2}\right.$ and cyclohexyl- $\left.\mathrm{H}\right), 3.56-3.69(\mathrm{~m}, 1 \mathrm{H}$, cyclohexyl- $H$ ), $4.13\left(\mathrm{t}, J=6.5 \mathrm{~Hz}, 2 \mathrm{H}, \mathrm{OCH}_{2}\right), 7.27(\mathrm{dd}, J=9.0,2.4 \mathrm{~Hz}$, $1 \mathrm{H}$, Naph- $H$ ), 7.42 (d, $J=2.4 \mathrm{~Hz}, 1 \mathrm{H}$, Naph- $H$ ), 7.57 (br d, $J=8.7 \mathrm{~Hz}$, $1 \mathrm{H}, \mathrm{NH}), 7.82(\mathrm{dd}, J=8.7,1.8 \mathrm{~Hz}, 1 \mathrm{H}, \mathrm{Naph}-H), 7.94(\mathrm{~d}, J=8.7 \mathrm{~Hz}, 1 \mathrm{H}$, 
Naph-H), 8.02 (d, $J=9.0 \mathrm{~Hz}, 1 \mathrm{H}, \mathrm{Naph}-H), 8.34$ (d, $J=1.8 \mathrm{~Hz}, 1 \mathrm{H}$, Naph-H), 12.09 (br s, 1H, COOH); HRMS (ESI) $m / z$ calcd for $\mathrm{C}_{21} \mathrm{H}_{28} \mathrm{NO}_{5} \mathrm{~S}[\mathrm{M}+\mathrm{H}]^{+}$406.1688, found 406.1674; Anal. $\left(\mathrm{C}_{21} \mathrm{H}_{27} \mathrm{NO}_{5} \mathrm{~S}\right) \mathrm{C}, \mathrm{H}, \mathrm{N}$.

5.6.3.21. (1R,2R)-2-(6-butoxynaphthalene-2-sulfonamido)cyclohexanecarboxylic acid (31c). White solid (85 mg, 91\%); mp: $178.0-179.5{ }^{\circ} \mathrm{C} ;[\alpha]_{\mathrm{D}}{ }^{20}:+4.1$ (c 0.231 , DMSO); ${ }^{1} \mathrm{H}$ NMR $(300 \mathrm{MHz}$, DMSO- $\left.d_{6}\right): \delta 0.96\left(\mathrm{t}, J=7.4 \mathrm{~Hz}, 3 \mathrm{H}, \mathrm{CH}_{2} \mathrm{CH}_{3}\right), 0.99-1.16(\mathrm{~m}, 3 \mathrm{H}$, cyclohexyl- $H$ ), $1.28-1.57\left(\mathrm{~m}, 6 \mathrm{H}, \mathrm{CH}_{2} \mathrm{CH}_{3}\right.$ and cyclohexyl- $H$ ), 1.70-1.87 (m, $3 \mathrm{H}, \mathrm{OCH}_{2} \mathrm{CH}_{2}$ and cyclohexyl- $H$ ), 2.17 (td, $J=10.5$, $3.6 \mathrm{~Hz}, 1 \mathrm{H}$, cyclohexyl- $H$ ), 3.28-3.41 (m, $1 \mathrm{H}$, cyclohexyl- $H$, overlaps with water), 4.13 (t, $J=6.5 \mathrm{~Hz}, 2 \mathrm{H}, \mathrm{OCH}_{2}$ ), 7.27 (dd, $J=9.0,2.4 \mathrm{~Hz}$, $1 \mathrm{H}$, Naph- $H), 7.42(\mathrm{~d}, J=2.4 \mathrm{~Hz}, 1 \mathrm{H}, \mathrm{Naph}-H), 7.70($ br d, $J=8.9 \mathrm{~Hz}$, $1 \mathrm{H}, \mathrm{NH}), 7.74(\mathrm{dd}, J=8.7,1.8 \mathrm{~Hz}, 1 \mathrm{H}, \mathrm{Naph}-H), 7.93(\mathrm{~d}, J=8.7 \mathrm{~Hz}, 1 \mathrm{H}$, Naph-H), 8.03 (d, $J=9.0 \mathrm{~Hz}, 1 \mathrm{H}$, Naph- $H$ ), 8.31 (d, $J=1.8 \mathrm{~Hz}, 1 \mathrm{H}$, Naph- $H$ ), 12.08 (br s, $1 \mathrm{H}, \mathrm{COOH}$ ); ${ }^{13} \mathrm{C}$ NMR (100 MHz, DMSO- $d_{6}$ ): $\delta$ 13.64, 18.71, 23.65, 23.74, 28.17, 30.56, 31.62, 48.99, 53.23, 67.40, 106.68, 120.10, 122.84, 126.50, 126.77, 127.71, 130.67, 135.74, 137.19, 158.52, 174.74; HRMS (ESI) $m / z$ calcd for $\mathrm{C}_{21} \mathrm{H}_{28} \mathrm{NO}_{5} \mathrm{~S}[\mathrm{M}+\mathrm{H}]^{+}$ 406.1688, found 406.1704; Anal. $\left(\mathrm{C}_{21} \mathrm{H}_{27} \mathrm{NO}_{5} \mathrm{~S}\right) \mathrm{C}, \mathrm{H}, \mathrm{N}$.

5.6.3.22. 4-(6-Butoxynaphthalene-2-sulfonamido)cyclohexane-1, 3-dicarboxylic acid, racemate (31d). White solid (54 mg, 87\%); mp: $228.0-231.0{ }^{\circ} \mathrm{C} ;[\alpha]_{\mathrm{D}}{ }^{20}:+1.2$ (c 0.115 , DMSO); ${ }^{1} \mathrm{H}$ NMR (300 MHz, DMSO- $d_{6}$ ): $\delta 0.96$ (t, $\left.J=7.4 \mathrm{~Hz}, 3 \mathrm{H}, \mathrm{CH}_{2} \mathrm{CH}_{3}\right), 1.14-1.27$ ( $\mathrm{m}, 2 \mathrm{H}$, cyclohexyl- $H), 1.33-1.56\left(\mathrm{~m}, 4 \mathrm{H}, \mathrm{CH}_{2} \mathrm{CH}_{3}\right.$ and cyclohexyl- $\left.\mathrm{H}\right)$, 1.68-1.87 (m, $4 \mathrm{H}, \mathrm{OCH}_{2} \mathrm{CH}_{2}$ and cyclohexyl- $\left.\mathrm{H}\right), 2.04-2.19(\mathrm{~m}, 1 \mathrm{H}$, cyclohexyl- $H$ ), $2.45-2.52(\mathrm{~m}, 1 \mathrm{H}$, cyclohexyl- $H$, overlaps with DMSO), 3.86-3.97 (m, 1H, cyclohexyl- $H), 4.13(\mathrm{t}, J=6.5 \mathrm{~Hz}, 2 \mathrm{H}$, $\left.\mathrm{OCH}_{2}\right), 7.27(\mathrm{dd}, J=9.0,2.4 \mathrm{~Hz}, 1 \mathrm{H}$, Naph- $H), 7.42(\mathrm{~d}, J=2.4 \mathrm{~Hz}, 1 \mathrm{H}$, Naph-H), 7.70 (br d, $J=9.0 \mathrm{~Hz}, 1 \mathrm{H}, \mathrm{NH}), 7.81$ (dd, $J=8.7,1.8 \mathrm{~Hz}, 1 \mathrm{H}$, Naph-H), 7.93 (d, $J=8.7 \mathrm{~Hz}, 1 \mathrm{H}$, Naph-H), 8.02 (d, $J=9.0 \mathrm{~Hz}, 1 \mathrm{H}$, Naph-H), 8.31 (d, $J=1.8 \mathrm{~Hz}, 1 \mathrm{H}$, Naph-H), 12.06 (br s, 2H, $2 \times \mathrm{COOH}$ ); HRMS (ESI) $\mathrm{m} / z$ calcd for $\mathrm{C}_{22} \mathrm{H}_{28} \mathrm{NO}_{7} \mathrm{~S}[\mathrm{M}+\mathrm{H}]^{+}$ 450.1586, found 450.1585; Anal. $\left(\mathrm{C}_{22} \mathrm{H}_{27} \mathrm{NO}_{7} \mathrm{~S}\right) \mathrm{C}, \mathrm{H}, \mathrm{N}$.

5.6.3.23. 2-(4-(6-Butoxynaphthalene-2-sulfonamido)phenyl)acetic acid (31e). White solid (70 mg, 91\%); mp: 192.0-193.0 ${ }^{\circ} \mathrm{C} ;{ }^{1} \mathrm{H}$ NMR (300 MHz, DMSO- $\left.d_{6}\right): \delta 0.95\left(\mathrm{t}, J=7.4 \mathrm{~Hz}, 3 \mathrm{H}, \mathrm{CH}_{2} \mathrm{CH}_{3}\right), 1.39-1.54(\mathrm{~m}$, $\left.2 \mathrm{H}, \mathrm{CH}_{2} \mathrm{CH}_{3}\right), 1.70-1.82\left(\mathrm{~m}, 2 \mathrm{H}, \mathrm{OCH}_{2} \mathrm{CH}_{2}\right), 3.40$ (s, $\left.2 \mathrm{H}, \mathrm{CH}_{2} \mathrm{COO}\right), 4.11$ $\left(\mathrm{t}, J=6.5 \mathrm{~Hz}, 2 \mathrm{H}, \mathrm{OCH}_{2}\right), 7.00-7.11(\mathrm{~m}, 4 \mathrm{H}, \mathrm{Ar}-\mathrm{H}), 7.26$ (dd, $J=9.0$, $2.4 \mathrm{~Hz}, 1 \mathrm{H}, \mathrm{Ar}-H), 7.39(\mathrm{~d}, J=2.4 \mathrm{~Hz}, 1 \mathrm{H}, \mathrm{Ar}-H), 7.70(\mathrm{dd}, J=8.7,1.8 \mathrm{~Hz}$, $1 \mathrm{H}, \operatorname{Ar}-H), 7.92(\mathrm{~d}, J=8.7 \mathrm{~Hz}, 1 \mathrm{H}, \operatorname{Ar}-H), 8.00(\mathrm{~d}, J=9.0 \mathrm{~Hz}, 1 \mathrm{H}, \mathrm{Ar}-H)$, 8.32 (d, $J=1.8 \mathrm{~Hz}, 1 \mathrm{H}, \operatorname{Ar}-H$ ), 10.23 (br s, $1 \mathrm{H}, \mathrm{NH}), 12.18$ (br s, $1 \mathrm{H}$, $\mathrm{COOH}$ ); HRMS (ESI) $m / z$ calcd for $\mathrm{C}_{22} \mathrm{H}_{24} \mathrm{NO}_{5} \mathrm{~S}[\mathrm{M}+\mathrm{H}]^{+} 414.1375$, found 414.1358; Anal. $\left(\mathrm{C}_{22} \mathrm{H}_{23} \mathrm{NO}_{5} \mathrm{~S}\right) \mathrm{C}, \mathrm{H}, \mathrm{N}$.

5.6.3.24. 2-(6-Butoxynaphthalene-2-sulfonamido)-5-hydroxybenzoic acid (31f). Pale brown solid (116 mg, 84\%); mp: 196.0-198.0 ${ }^{\circ} \mathrm{C} ;{ }^{1} \mathrm{H}$ NMR (300 MHz, DMSO- $\left.d_{6}\right): \delta 0.94\left(\mathrm{t}, J=7.4 \mathrm{~Hz}, 3 \mathrm{H}, \mathrm{CH}_{2} \mathrm{CH}_{3}\right)$, 1.39-1.53 (m, $\left.2 \mathrm{H}, \mathrm{CH}_{2} \mathrm{CH}_{3}\right), 1.69-1.82\left(\mathrm{~m}, 2 \mathrm{H}, \mathrm{OCH}_{2} \mathrm{CH}_{2}\right), 4.10(\mathrm{t}$, $\left.J=6.5 \mathrm{~Hz}, 2 \mathrm{H}, \mathrm{OCH}_{2}\right), 6.95(\mathrm{dd}, J=9.0,3.0 \mathrm{~Hz}, 1 \mathrm{H}, \mathrm{Ar}-\mathrm{H}), 7.16(\mathrm{~d}$, $J=3.0 \mathrm{~Hz}, 1 \mathrm{H}, \mathrm{Ar}-H), 7.26$ (dd, $J=9.0,2.4 \mathrm{~Hz}, 1 \mathrm{H}, \mathrm{Ar}-H), 7.36-7.44$ $(\mathrm{m}, 2 \mathrm{H}, \mathrm{Ar}-\mathrm{H}), 7.55(\mathrm{dd}, J=8.7,1.8 \mathrm{~Hz}, 1 \mathrm{H}, \mathrm{Ar}-H), 7.87(\mathrm{~d}, J=8.7 \mathrm{~Hz}$, $1 \mathrm{H}, \mathrm{Ar}-H), 8.00(\mathrm{~d}, J=9.0 \mathrm{~Hz}, 1 \mathrm{H}, \mathrm{Ar}-H), 8.30(\mathrm{~d}, J=1.8 \mathrm{~Hz}, 1 \mathrm{H}, \mathrm{Ar}-H)$, 9.61 (s, 1H, OH), 10.44 (br s, 1H, NH), 13.56 (br s, 1H, COOH); HRMS (ESI) $\mathrm{m} / \mathrm{z}$ calcd for $\mathrm{C}_{21} \mathrm{H}_{20} \mathrm{NO}_{6} \mathrm{~S}[\mathrm{M}-\mathrm{H}]^{-}$414.1011, found 414.1013; Anal. $\left(\mathrm{C}_{21} \mathrm{H}_{21} \mathrm{NO}_{6} \mathrm{~S}\right) \mathrm{C}, \mathrm{H}, \mathrm{N}$.

5.6.3.25. 2-(6-Butoxynaphthalene-2-sulfonamido)terephthalic acid (31g). White solid (149 mg, 87\%); mp: $233.0-234.0{ }^{\circ} \mathrm{C} ;{ }^{1} \mathrm{H}$ NMR (300 MHz, DMSO- $d_{6}$ ): $\delta 0.94\left(\mathrm{t}, J=7.4 \mathrm{~Hz}, 3 \mathrm{H}, \mathrm{CH}_{2} \mathrm{CH}_{3}\right), 1.39-1.53$ $\left(\mathrm{m}, 2 \mathrm{H}, \mathrm{CH}_{2} \mathrm{CH}_{3}\right), 1.68-1.81\left(\mathrm{~m}, 2 \mathrm{H}, \mathrm{OCH}_{2} \mathrm{CH}_{2}\right), 4.10(\mathrm{t}, J=6.5 \mathrm{~Hz}, 2 \mathrm{H}$, $\left.\mathrm{OCH}_{2}\right), 7.28(\mathrm{dd}, J=9.0,2.4 \mathrm{~Hz}, 1 \mathrm{H}, \mathrm{Ar}-\mathrm{H}), 7.40(\mathrm{~d}, J=2.4 \mathrm{~Hz}, 1 \mathrm{H}, \mathrm{Ar}-$
$H$ ), 7.59 (dd, $J=8.1,1.5 \mathrm{~Hz}, 1 \mathrm{H}, \mathrm{Ar}-H), 7.68(\mathrm{dd}, J=8.7,1.8 \mathrm{~Hz}, 1 \mathrm{H}$, Ar- $H$ ), 7.90-7.93 (m, 2H, Ar-H), 8.03 (d, $J=9.0 \mathrm{~Hz}, 1 \mathrm{H}, \mathrm{Ar}-H), 8.11$ (d, $J=1.5 \mathrm{~Hz}, 1 \mathrm{H}, \operatorname{Ar}-H), 8.44$ (d, $J=1.8 \mathrm{~Hz}, 1 \mathrm{H}, \operatorname{Ar}-H), 11.14$ (br s, $1 \mathrm{H}$, $\mathrm{NH}), 13.20$ (br s, $2 \mathrm{H}, 2 \times \mathrm{COOH}) ;{ }^{13} \mathrm{C}$ NMR $\left(100 \mathrm{MHz}, \mathrm{DMSO}-d_{6}\right)$ : $\delta$ 13.61, 18.67, 30.48, 67.51, 106.71, 119.17, 120.39, 120.68, 122.19, 123.59, 126.65, 128.27, 128.35, 130.87, 131.80, 132.64, 135.50, 136.44, 139.67, 159.17, 165.91, 169.03; HRMS (ESI) $m / z$ calcd for $\mathrm{C}_{22} \mathrm{H}_{20} \mathrm{NO}_{7} \mathrm{~S}$ $[\mathrm{M}-\mathrm{H}]^{-}$442.0960, found 442.0962; Anal. $\left(\mathrm{C}_{22} \mathrm{H}_{21} \mathrm{NO}_{7} \mathrm{~S}\right) \mathrm{C}, \mathrm{H}, \mathrm{N}$.

5.6.3.26. 5-(6-Butoxynaphthalene-2-sulfonamido)isophthalic acid (31h). White solid (96 mg, 98\%); mp: $233.5-235.0{ }^{\circ} \mathrm{C} ;{ }^{1} \mathrm{H}$ NMR (300 MHz, DMSO- $\left.d_{6}\right): \delta 0.94\left(\mathrm{t}, J=7.4 \mathrm{~Hz}, 3 \mathrm{H}, \mathrm{CH}_{2} \mathrm{CH}_{3}\right), 1.39-1.52$ $\left(\mathrm{m}, 2 \mathrm{H}, \mathrm{CH}_{2} \mathrm{CH}_{3}\right), 1.68-1.81\left(\mathrm{~m}, 2 \mathrm{H}, \mathrm{OCH}_{2} \mathrm{CH}_{2}\right), 4.10(\mathrm{t}, J=6.5 \mathrm{~Hz}$, $\left.2 \mathrm{H}, \mathrm{OCH}_{2}\right), 7.26(\mathrm{dd}, J=9.0,2.4 \mathrm{~Hz}, 1 \mathrm{H}, \mathrm{Ar}-\mathrm{H}), 7.39(\mathrm{~d}, J=2.4 \mathrm{~Hz}$, $1 \mathrm{H}, \mathrm{Ar}-\mathrm{H}), 7.69(\mathrm{dd}, J=8.7,1.8 \mathrm{~Hz}, 1 \mathrm{H}, \mathrm{Ar}-\mathrm{H}), 7.90-7.97(\mathrm{~m}, 3 \mathrm{H}, \mathrm{Ar}-$ $H), 8.02(\mathrm{~d}, J=9.0 \mathrm{~Hz}, 1 \mathrm{H}, \mathrm{Ar}-H), 8.07$ (dd, $J=1.5,1.5 \mathrm{~Hz}, 1 \mathrm{H}, \mathrm{Ar}-H)$, 8.35 (d, $J=1.8 \mathrm{~Hz}, 1 \mathrm{H}, \mathrm{Ar}-\mathrm{H}), 10.75$ (br s, $1 \mathrm{H}, \mathrm{NH}$ ), 13.23 (br s, $2 \mathrm{H}$, $2 \times \mathrm{COOH}$ ); HRMS (ESI) $\mathrm{m} / z$ calcd for $\mathrm{C}_{22} \mathrm{H}_{20} \mathrm{NO}_{7} \mathrm{~S}[\mathrm{M}-\mathrm{H}]^{-}$ 442.0960, found 442.0968; Anal. $\left(\mathrm{C}_{22} \mathrm{H}_{21} \mathrm{NO}_{7} \mathrm{~S}\right) \mathrm{C}, \mathrm{H}, \mathrm{N}$.

5.6.3.27. 4-(6-Butoxynaphthalene-2-sulfonamido)isophthalic acid (31i). White solid (102 mg, 86\%); mp: $243.0-244.0{ }^{\circ} \mathrm{C} ;{ }^{1} \mathrm{H}$ NMR (300 MHz, DMSO- $\left.d_{6}\right): \delta 0.93\left(\mathrm{t}, J=7.4 \mathrm{~Hz}, 3 \mathrm{H}, \mathrm{CH}_{2} \mathrm{CH}_{3}\right), 1.38-1.52$ $\left(\mathrm{m}, 2 \mathrm{H}, \mathrm{CH}_{2} \mathrm{CH}_{3}\right), 1.69-1.81\left(\mathrm{~m}, 2 \mathrm{H}, \mathrm{OCH}_{2} \mathrm{CH}_{2}\right), 4.10(\mathrm{t}, J=6.5 \mathrm{~Hz}$, $2 \mathrm{H}, \mathrm{OCH}_{2}$ ), 7.29 (dd, $\left.J=9.0,2.4 \mathrm{~Hz}, 1 \mathrm{H}, \operatorname{Ar}-H\right), 7.41(\mathrm{~d}, J=2.4 \mathrm{~Hz}$, $1 \mathrm{H}, \mathrm{Ar}-H), 7.66(\mathrm{~d}, J=8.7 \mathrm{~Hz}, 1 \mathrm{H}, \mathrm{Ar}-H), 7.77(\mathrm{dd}, J=8.7,1.8 \mathrm{~Hz}, 1 \mathrm{H}$, $\operatorname{Ar}-H), 7.95(\mathrm{~d}, J=8.7 \mathrm{~Hz}, 1 \mathrm{H}, \mathrm{Ar}-H), 8.02(\mathrm{dd}, J=8.7,2.1 \mathrm{~Hz}, 1 \mathrm{H}, \mathrm{Ar}-$ $H), 8.08(\mathrm{~d}, J=9.0 \mathrm{~Hz}, 1 \mathrm{H}, \operatorname{Ar}-H), 8.43(\mathrm{~d}, J=2.1 \mathrm{~Hz}, 1 \mathrm{H}, \operatorname{Ar}-H), 8.58$ (d, $J=1.8 \mathrm{~Hz}, 1 \mathrm{H}, \mathrm{Ar}-H), 11.55$ (br s, $1 \mathrm{H}, \mathrm{NH}$ ), 12.89 (br s, $2 \mathrm{H}$, $2 \times \mathrm{COOH}$ ); HRMS (ESI) $m / z$ calcd for $\mathrm{C}_{22} \mathrm{H}_{21} \mathrm{NO}_{7} \mathrm{SNa}[\mathrm{M}+\mathrm{Na}]^{+}$ 466.0936, found 466.0932; Anal. $\left(\mathrm{C}_{22} \mathrm{H}_{21} \mathrm{NO}_{7} \mathrm{~S}\right) \mathrm{C}, \mathrm{H}, \mathrm{N}$.

5.6.3.28. 1-(6-(4-Cyano-2-fluorobenzyloxy)naphthalen-2-ylsulfonyl) piperidine-4-carboxylic acid (32a). White solid (38 mg, 65\%); $\mathrm{mp}$ : 217.0-218.0 ${ }^{\circ} \mathrm{C} ;{ }^{1} \mathrm{H}$ NMR (300 MHz, DMSO-d $)$ : $\delta 1.47-1.65(\mathrm{~m}, 2 \mathrm{H}$, piperidyl- $H$ ), $1.80-1.94(\mathrm{~m}, 2 \mathrm{H}$, piperidyl $H), 2.17-2.31(\mathrm{~m}, 1 \mathrm{H}$, piperidyl- $H$ ), 2.48 (td, $J=11.1,1.8 \mathrm{~Hz}, 2 \mathrm{H}$, piperidyl- $H$ ), 3.52 (dt, $J=11.8,3.9 \mathrm{~Hz}, 2 \mathrm{H}$, piperidyl $-H), 5.43\left(\mathrm{~s}, 2 \mathrm{H}, \mathrm{OCH}_{2}\right), 7.43$ (dd, $J=9.0$, $2.4 \mathrm{~Hz}, 1 \mathrm{H}, \mathrm{Ar}-H), 7.65(\mathrm{~d}, J=2.4 \mathrm{~Hz}, 1 \mathrm{H}, \mathrm{Ar}-H), 7.71$ (dd, $J=8.7$, $1.8 \mathrm{~Hz}, 1 \mathrm{H}, \mathrm{Ar}-H), 7.81-7.88$ (m, 2H, Ar- $H$ ), 7.95 (dd, $J=9.9,1.2 \mathrm{~Hz}$, $1 \mathrm{H}, \mathrm{Ar}-H), 8.04(\mathrm{~d}, J=8.7 \mathrm{~Hz}, 1 \mathrm{H}, \mathrm{Ar}-H), 8.16(\mathrm{~d}, J=9.0 \mathrm{~Hz}, 1 \mathrm{H}, \mathrm{Ar}-\mathrm{H})$, 8.36 (d, $J=1.2 \mathrm{~Hz}, 1 \mathrm{H}, \mathrm{Ar}-\mathrm{H}$ ), 12.22 (br s, $1 \mathrm{H}, \mathrm{COOH}$ ); HRMS (ESI) $m / z$ calcd for $\mathrm{C}_{24} \mathrm{H}_{20} \mathrm{FN}_{2} \mathrm{O}_{5} \mathrm{~S}[\mathrm{M}-\mathrm{H}]^{-}$467.1077, found 467.1068; Anal. $\left(\mathrm{C}_{24} \mathrm{H}_{21} \mathrm{FN}_{2} \mathrm{O}_{5} \mathrm{~S}\right) \mathrm{C}, \mathrm{H}, \mathrm{N}$.

5.6.3.29. (1R,2S)-2-(6-(4-cyano-2-fluorobenzyloxy)naphthalene-2-sulfonamido)cyclohexanecarboxylic acid (32b). White solid (95 mg, 67\%); mp: $187.0-189.0{ }^{\circ} \mathrm{C} ;[\alpha]_{\mathrm{D}}{ }^{20}:+25.8$ (c 0.149 , DMSO); ${ }^{1} \mathrm{H}$ NMR $\left(300 \mathrm{MHz}\right.$, DMSO- $\left.d_{6}\right): \delta 1.05-1.31(\mathrm{~m}, 3 \mathrm{H}$, cyclohexyl- $H), 1.37-1.62$ (m, 4H, cyclohexyl- $H), 1.74-1.70(\mathrm{~m}, 1 \mathrm{H}$, cyclohexyl- $H), 2.47-2.55(\mathrm{~m}$, $1 \mathrm{H}$, cyclohexyl- $H)$, 3.60-3.75 (m, $1 \mathrm{H}$, cyclohexyl- $H), 5.47(\mathrm{~s}, 2 \mathrm{H}$, $\mathrm{OCH}_{2}$ ), 7.45 (dd, $\left.J=9.0,2.1 \mathrm{~Hz}, 1 \mathrm{H}, \mathrm{Ar}-\mathrm{H}\right), 7.65(\mathrm{~d}, J=2.1 \mathrm{~Hz}, 1 \mathrm{H}, \mathrm{Ar}-\mathrm{H})$, 7.80-7.94 (m, 3H, Ar-H), 7.97-8.06 (m, 2H, Ar-H), $8.14(\mathrm{~d}, J=9.0 \mathrm{~Hz}$, $1 \mathrm{H}, \mathrm{Ar}-H), 8.43(\mathrm{~d}, J=1.2 \mathrm{~Hz}, 1 \mathrm{H}, \mathrm{Ar}-\mathrm{H})$, resonance for $\mathrm{NH}$ missing, 12.09 (br s, $1 \mathrm{H}, \mathrm{COOH}$ ); HRMS (ESI) $\mathrm{m} / z$ calcd for $\mathrm{C}_{25} \mathrm{H}_{22} \mathrm{FN}_{2} \mathrm{O}_{5} \mathrm{~S}$ $[\mathrm{M}-\mathrm{H}]^{-}$481.1233, found 481.1220; Anal. $\left(\mathrm{C}_{25} \mathrm{H}_{23} \mathrm{FN}_{2} \mathrm{O}_{5} \mathrm{~S}\right) \mathrm{C}, \mathrm{H}, \mathrm{N}$.

5.6.3.30. (1R,2R)-2-(6-(4-cyano-2-fluorobenzyloxy)naphthalene-2sulfonamido)cyclohexanecarboxylic acid (32c). White solid (92 mg, 65\%); mp: $212.0-214.5{ }^{\circ} \mathrm{C} ;[\alpha]_{\mathrm{D}}{ }^{20}:+13.9$ ( c 0.024, DMSO); ${ }^{1} \mathrm{H}$ NMR (300 MHz, DMSO- $\left.d_{6}\right): \delta \quad 0.91-1.19(\mathrm{~m}, 3 \mathrm{H}$, cyclohexyl-H), 1.28-1.59 (m, 4H, cyclohexyl- $H), 1.73-1.86(\mathrm{~m}, 1 \mathrm{H}$, cyclohexyl- $H)$, $2.17(\mathrm{td}, J=10.4,3.6,1 \mathrm{H}$, cyclohexyl- $H), 3.27-3.39(\mathrm{~m}, 1 \mathrm{H}$, cyclohexyl- $\mathrm{H}$, overlaps with water), $5.41\left(\mathrm{~s}, 2 \mathrm{H}, \mathrm{OCH}_{2}\right), 7.39(\mathrm{dd}, J=9.0$, $2.1 \mathrm{~Hz}, 1 \mathrm{H}, \operatorname{Ar}-H), 7.59(\mathrm{~d}, J=2.1 \mathrm{~Hz}, 1 \mathrm{H}, \mathrm{Ar}-H), 7.74-7.89(\mathrm{~m}, 3 \mathrm{H}$, 
Ar- $H$ ), 7.91-8.02 (m, 2H, Ar-H), 8.09 (d, $J=9.0 \mathrm{~Hz}, 1 \mathrm{H}, \mathrm{Ar}-\mathrm{H}), 8.35$ (d, $J=1.2 \mathrm{~Hz}, 1 \mathrm{H}, \mathrm{Ar}-H$ ), resonance for $\mathrm{NH}$ missing, 12.08 (br s, $1 \mathrm{H}$, $\mathrm{COOH}) ;{ }^{13} \mathrm{C}$ NMR (100 MHz, DMSO- $\left.d_{6}\right): \delta 23.57,23.67,28.18,31.67$, $48.95,53.28,63.19$ and $63.23\left(1 \mathrm{C},{ }^{3} \mathrm{~J}_{\mathrm{F}, \mathrm{C}}=4.4 \mathrm{~Hz}\right), 107.42,112.40$ and $112.50\left(1 \mathrm{C},{ }^{3} J_{\mathrm{F}, \mathrm{C}}=10.3 \mathrm{~Hz}\right), 117.49$ and $117.51\left(1 \mathrm{C},{ }^{4} \mathrm{~J}, \mathrm{C}=2.7 \mathrm{~Hz}\right)$, 119.26 and $119.51\left(1 \mathrm{C},{ }^{2} J_{\mathrm{F}, \mathrm{C}}=25.7 \mathrm{~Hz}\right), 119.89,123.04,126.53$, $127.18,127.88,128.95$ and $128.99\left(1 \mathrm{C},{ }^{3} J_{\mathrm{F}, \mathrm{C}}=5.1 \mathrm{~Hz}\right), 129.70$ and $129.84\left(1 \mathrm{C},{ }^{2} J_{\mathrm{F}, \mathrm{C}}=15.4 \mathrm{~Hz}\right), 130.96,131.04$ and $131.09(1 \mathrm{C}$, $\left.{ }^{4} J_{\mathrm{F}, \mathrm{C}}=3.7 \mathrm{~Hz}\right), 135.52,137.64,157.60,158.28$ and $160.75(1 \mathrm{C}$, ${ }^{1} J_{\mathrm{F}, \mathrm{C}}=249.0 \mathrm{~Hz}$ ), 174.78; HRMS (ESI) $\mathrm{m} / z$ calcd for $\mathrm{C}_{25} \mathrm{H}_{22} \mathrm{FN}_{2} \mathrm{O}_{5} \mathrm{~S}$ $[\mathrm{M}-\mathrm{H}]^{-}$481.1233, found 481.1246; Anal. $\left(\mathrm{C}_{25} \mathrm{H}_{23} \mathrm{FN}_{2} \mathrm{O}_{5} \mathrm{~S}\right) \mathrm{C}, \mathrm{H}, \mathrm{N}$.

5.6.3.31. 4-(6-(4-Cyano-2-fluorobenzyloxy)naphthalene-2-sulfonamido)cyclohexane-1,3-dicarboxylic acid, racemate (32d). White solid (64 mg, 64\%); mp: $238.0-240.5{ }^{\circ} \mathrm{C} ;[\alpha]_{\mathrm{D}}{ }^{20}:+1.3$ (c 0.079 , DMSO); ${ }^{1} \mathrm{H}$ NMR (300 MHz, DMSO- $\left.d_{6}\right): \delta 1.20-1.31(\mathrm{~m}, 2 \mathrm{H}$, cyclohexyl- $H$ ), $1.34-1.58(\mathrm{~m}, 2 \mathrm{H}$, cyclohexyl-H), 1.67-1.86 (m, $2 \mathrm{H}$, cyclohexyl- $H$ ), 2.05-2.18 ( $\mathrm{m}, 1 \mathrm{H}$, cyclohexyl- $H), 2.46-2.52(\mathrm{~m}$, $1 \mathrm{H}$, cyclohexyl- $H$, overlaps with DMSO), 3.84-3.94 $(\mathrm{m}, 1 \mathrm{H}$, cyclohexyl- $H$ ), $5.41\left(\mathrm{~s}, 2 \mathrm{H}, \mathrm{OCH}_{2}\right), 7.39$ (dd, $J=9.0,2.0 \mathrm{~Hz}, 1 \mathrm{H}, \mathrm{Ar}-$ $H), 7.60(\mathrm{~d}, J=2.0 \mathrm{~Hz}, 1 \mathrm{H}, \operatorname{Ar}-H), 7.75-7.88(\mathrm{~m}, 3 \mathrm{H}, \mathrm{Ar}-H)$, 7.92-8.01 (m, 2H, Ar- $H$ ), 8.08 (d, $J=9.0 \mathrm{~Hz}, 1 \mathrm{H}, \operatorname{Ar}-H), 8.35$ (d, $J=1.1 \mathrm{~Hz}, 1 \mathrm{H}, \mathrm{Ar}-\mathrm{H}$ ), resonance for $\mathrm{NH}$ missing, 12.05 (br s, $2 \mathrm{H}$, $2 \times \mathrm{COOH}$ ); HRMS (ESI) $\mathrm{m} / z$ calcd for $\mathrm{C}_{26} \mathrm{H}_{24} \mathrm{FN}_{2} \mathrm{O}_{7} \mathrm{~S}[\mathrm{M}+\mathrm{H}]^{+}$ 527.1288, found 527.1271; Anal. $\left(\mathrm{C}_{26} \mathrm{H}_{23} \mathrm{FN}_{2} \mathrm{O}_{7} \mathrm{~S}\right) \mathrm{C}, \mathrm{H}, \mathrm{N}$.

5.6.3.32. 2-(4-(6-(4-Cyano-2-fluorobenzyloxy)naphthalene-2-sulfonamido)phenyl)acetic acid (32e). White solid (82 $\mathrm{mg}, 84 \%)$ mp: 187.0-190.0 ${ }^{\circ} \mathrm{C} ;{ }^{1} \mathrm{H}$ NMR (300 MHz, DMSO- $\left.d_{6}\right): \delta 3.10(\mathrm{~s}, 2 \mathrm{H}$, $\left.\mathrm{CH}_{2} \mathrm{COO}\right), 5.38\left(\mathrm{~s}, 2 \mathrm{H}, \mathrm{OCH}_{2}\right), 6.85-6.91(\mathrm{~m}, 2 \mathrm{H}, \mathrm{Ar}-\mathrm{H}), 6.92-6.98(\mathrm{~m}$, $2 \mathrm{H}, \operatorname{Ar}-H), 7.33$ (dd, $J=9.0,2.4 \mathrm{~Hz}, 1 \mathrm{H}, \operatorname{Ar}-H), 7.52$ (d, $J=2.4 \mathrm{~Hz}, 1 \mathrm{H}$, Ar-H), 7.69-7.86 (m, 3H, Ar-H), 7.87-8.96 (m, 2H, Ar-H), 8.02 (d, $J=9.0 \mathrm{~Hz}, 1 \mathrm{H}, \mathrm{Ar}-H), 8.28(\mathrm{~d}, J=1.1 \mathrm{~Hz}, 1 \mathrm{H}, \mathrm{Ar}-H), 10.25$ (br s, $1 \mathrm{H}, \mathrm{NH})$, 12.16 (br s, $1 \mathrm{H}, \mathrm{COOH}$ ); HRMS (ESI) $m / z$ calcd for $\mathrm{C}_{26} \mathrm{H}_{18} \mathrm{FN}_{2} \mathrm{O}_{5} \mathrm{~S}$ $[\mathrm{M}-\mathrm{H}]^{-}$489.0920, found 489.0925; Anal. $\left(\mathrm{C}_{26} \mathrm{H}_{19} \mathrm{FN}_{2} \mathrm{O}_{5} \mathrm{~S}\right) \mathrm{C}, \mathrm{H}, \mathrm{N}$.

5.6.3.33. 2-(6-(4-Cyano-2-fluorobenzyloxy)naphthalene-2-sulfonamido)-5-hydroxybenzoic acid (32f). White solid (78 mg, 59\%); mp: 216.0-217.0 ${ }^{\circ} \mathrm{C} ;{ }^{1} \mathrm{H}$ NMR (300 MHz, DMSO- $\left.d_{6}\right): \delta 5.39\left(\mathrm{~s}, 2 \mathrm{H}, \mathrm{OCH}_{2}\right)$, $6.95(\mathrm{dd}, J=9.0,3.0 \mathrm{~Hz}, 1 \mathrm{H}, \mathrm{Ar}-H), 7.16(\mathrm{~d}, J=3.0 \mathrm{~Hz}, 1 \mathrm{H}, \mathrm{Ar}-H)$, 7.35-7.44 (m, 2H, Ar-H), 7.54-7.61 (m, 2H, Ar-H), 7.76 (dd, $J=8.0$, $1.4 \mathrm{~Hz}, 1 \mathrm{H}, \mathrm{Ar}-\mathrm{H}), 7.80$ (d, $J=8.0 \mathrm{~Hz}, 1 \mathrm{H}, \mathrm{Ar}-H), 7.88-7.96(\mathrm{~m}, 2 \mathrm{H}, \mathrm{Ar}-$ $H), 8.06(\mathrm{~d}, J=9.0 \mathrm{~Hz}, 1 \mathrm{H}, \mathrm{Ar}-H), 8.33(\mathrm{~d}, J=1.4 \mathrm{~Hz}, 1 \mathrm{H}, \mathrm{Ar}-H), 9.62(\mathrm{~s}$, $1 \mathrm{H}, \mathrm{OH}$ ), 10.45 (br s, $1 \mathrm{H}, \mathrm{NH}$ ), 13.67 (br s, $1 \mathrm{H}, \mathrm{COOH}$ ); HRMS (ESI) m/z calcd for $\mathrm{C}_{25} \mathrm{H}_{16} \mathrm{FN}_{2} \mathrm{O}_{6} \mathrm{~S}[\mathrm{M}-\mathrm{H}]^{-}$491.0713, found 491.0701; Anal. $\left(\mathrm{C}_{25} \mathrm{H}_{17} \mathrm{FN}_{2} \mathrm{O}_{6} \mathrm{~S}\right) \mathrm{C}, \mathrm{H}, \mathrm{N}$.

5.6.3.34. 2-(6-(4-Cyano-2-fluorobenzyloxy)naphthalene-2-sulfonamido)terephthalic acid (32g). White solid (35 $\mathrm{mg}, 59 \%)$; mp: 244.0-245.0 ${ }^{\circ} \mathrm{C} ;{ }^{1} \mathrm{H}$ NMR (300 MHz, DMSO- $\left.d_{6}\right): \delta 5.39(\mathrm{~s}, 2 \mathrm{H}$, $\mathrm{OCH}_{2}$ ), 7.38 (dd, $\left.J=9.0,2.4 \mathrm{~Hz}, 1 \mathrm{H}, \mathrm{Ar}-H\right), 7.52(\mathrm{dd}, J=8.1,1.4 \mathrm{~Hz}$, $1 \mathrm{H}, \mathrm{Ar}-\mathrm{H}$ ), 7.57 (d, $J=2.4 \mathrm{~Hz}, 1 \mathrm{H}, \mathrm{Ar}-H), 7.70$ (dd, $J=8.7,1.8 \mathrm{~Hz}$, $1 \mathrm{H}, \operatorname{Ar}-H), 7.73-7.85(\mathrm{~m}, 2 \mathrm{H}, \operatorname{Ar}-H), 7.90-7.98(\mathrm{~m}, 3 \mathrm{H}, \operatorname{Ar}-H)$, 8.05-8.11 (m, 2H, Ar-H), 8.44 (d, $J=1.4 \mathrm{~Hz}, 1 \mathrm{H}, \operatorname{Ar}-H), 10.95$ (br s, $1 \mathrm{H}, \mathrm{NH}), 13.20$ (br s, $2 \mathrm{H}, 2 \times \mathrm{COOH}$ ); HRMS (ESI) $\mathrm{m} / \mathrm{z}$ calcd for $\mathrm{C}_{26} \mathrm{H}_{16} \mathrm{FN}_{2} \mathrm{O}_{7} \mathrm{~S}[\mathrm{M}-\mathrm{H}]^{-}$519.0662, found 519.0646; Anal. $\left(\mathrm{C}_{26} \mathrm{H}_{17} \mathrm{FN}_{2} \mathrm{O}_{7} \mathrm{~S}\right) \mathrm{C}, \mathrm{H}, \mathrm{N}$.

5.6.3.35. 5-(6-(4-Cyano-2-fluorobenzyloxy)naphthalene-2-sulfonamido)isophthalic acid (32h). White solid (32 mg, 56\%); mp: 262.0-264.0 ${ }^{\circ} \mathrm{C}$; ${ }^{1} \mathrm{H}$ NMR (300 MHz, DMSO- $\left.d_{6}\right): \delta 5.39(\mathrm{~s}, 2 \mathrm{H}$, $\left.\mathrm{OCH}_{2}\right), 7.38(\mathrm{dd}, J=9.0,2.4 \mathrm{~Hz}, 1 \mathrm{H}, \mathrm{Ar}-\mathrm{H}), 7.57(\mathrm{~d}, J=2.4 \mathrm{~Hz}, 1 \mathrm{H}, \mathrm{Ar}-$ $H)$, 7.70-7.85 (m, 3H, Ar-H), 7.88-7.95 (m, 3H, Ar-H), 7.97 (d, $J=9.0 \mathrm{~Hz}, 1 \mathrm{H}, \operatorname{Ar}-H), 8.05-8.11(\mathrm{~m}, 2 \mathrm{H}, \operatorname{Ar}-H), 8.35(\mathrm{~d}, J=1.4 \mathrm{~Hz}$, $1 \mathrm{H}, \mathrm{Ar}-\mathrm{H}$ ), 10.80 (br s, $1 \mathrm{H}, \mathrm{NH}), 12.83$ (br s, $2 \mathrm{H}, 2 \times \mathrm{COOH}$ ); HRMS
(ESI) $\mathrm{m} / z$ calcd for $\mathrm{C}_{26} \mathrm{H}_{17} \mathrm{FN}_{2} \mathrm{O}_{7} \mathrm{SNa}[\mathrm{M}+\mathrm{Na}]^{+}$543.0638, found 543.0641; Anal. $\left(\mathrm{C}_{26} \mathrm{H}_{17} \mathrm{FN}_{2} \mathrm{O}_{7} \mathrm{~S}\right) \mathrm{C}, \mathrm{H}, \mathrm{N}$.

5.6.3.36. 4-(6-(4-Cyano-2-fluorobenzyloxy)naphthalene-2-sulfonamido)isophthalic acid (32i). White solid (62 $\mathrm{mg}, 68 \%$ ); $\mathrm{mp}$ : 258.0-260.5 ${ }^{\circ} \mathrm{C} ;{ }^{1} \mathrm{H}$ NMR (300 MHz, DMSO- $\left.d_{6}\right): \delta 5.37(\mathrm{~s}, 2 \mathrm{H}$, $\left.\mathrm{OCH}_{2}\right), 7.34(\mathrm{dd}, J=9.0,2.4 \mathrm{~Hz}, 1 \mathrm{H}, \mathrm{Ar}-\mathrm{H}), 7.40(\mathrm{~d}, J=8.7 \mathrm{~Hz}, 1 \mathrm{H}, \mathrm{Ar}-$ $H$ ), 7.53 (d, $J=2.4 \mathrm{~Hz}, 1 \mathrm{H}, \mathrm{Ar}-H), 7.67-7.84(\mathrm{~m}, 4 \mathrm{H}, \mathrm{Ar}-H), 7.88$ (d, $J=9.0 \mathrm{~Hz}, 1 \mathrm{H}, \operatorname{Ar}-H), 7.92(\mathrm{dd}, J=9.1,1.5 \mathrm{~Hz}, 1 \mathrm{H}, \operatorname{Ar}-H), 8.07$ (d, $J=9.0 \mathrm{~Hz}, 1 \mathrm{H}, \mathrm{Ar}-\mathrm{H}), 8.39-8.44$ (m, 2H, Ar-H), 11.03 (br s, $1 \mathrm{H}, \mathrm{NH}$ ), 12.12 (br s, $2 \mathrm{H}, 2 \times \mathrm{COOH}$ ); ${ }^{13} \mathrm{C}$ NMR (100 MHz, DMSO- $d_{6}$ ): $\delta 63.23$ and $63.26\left(1 \mathrm{C},{ }^{3} \mathrm{~J}_{\mathrm{F}, \mathrm{C}}=4.4 \mathrm{~Hz}\right), 107.44,112.39$ and $112.49(1 \mathrm{C}$, $\left.{ }^{3} J_{\mathrm{F}, \mathrm{C}}=9.9 \mathrm{~Hz}\right), 117.03,117.48$ and $117.50\left(1 \mathrm{C},{ }^{4} J_{\mathrm{F}, \mathrm{C}}=2.5 \mathrm{~Hz}\right), 119.24$ and $119.49\left(1 \mathrm{C},{ }^{2} J_{\mathrm{F}, \mathrm{C}}=24.9 \mathrm{~Hz}\right), 120.23,122.68,123.36,127.11$, $128.04,128.10,128.32,128.93$ and $128.97\left(1 \mathrm{C},{ }^{3} J_{\mathrm{F}, \mathrm{C}}=5.1 \mathrm{~Hz}\right), 129.58$ and $129.73\left(1 \mathrm{C},{ }^{2} J_{\mathrm{F}, \mathrm{C}}=15.4 \mathrm{~Hz}\right), 131.01$ and $131.06(1 \mathrm{C}$, $\left.{ }^{4} J_{\mathrm{F}, \mathrm{C}}=3.7 \mathrm{~Hz}\right), 131.13,132.73,134.27,134.48,135.98,145.57,158.00$, 158.25 and $160.73\left(1 \mathrm{C},{ }^{1} J_{\mathrm{F}, \mathrm{C}}=249.1 \mathrm{~Hz}\right), 166.17,169.97$; HRMS (ESI) $\mathrm{m} / \mathrm{z}$ calcd for $\mathrm{C}_{26} \mathrm{H}_{16} \mathrm{FN}_{2} \mathrm{O}_{7} \mathrm{~S}[\mathrm{M}-\mathrm{H}]^{-}$519.0662, found 519.0654; Anal. $\left(\mathrm{C}_{26} \mathrm{H}_{17} \mathrm{FN}_{2} \mathrm{O}_{7} \mathrm{~S}\right) \mathrm{C}, \mathrm{H}, \mathrm{N}$.

\section{Acknowledgements}

This work was supported by the EUR-INTAFAR European Union FP6 Integrated Project (Project no. LSHM-CT-2004-512138) under the thematic priority of Life Sciences, Genomics and Biotechnology for Health, and the Slovenian Research Agency.

\section{Appendix. Supplementary data}

The supplementary data associated with this article can be found in the on-line version at doi:10.1016/j.ejmech.2011.04.011.

\section{References}

[1] H.W. Boucher, G.H. Talbot, J.S. Bradley, J.E. Edwards Jr., D. Gilbert, L.B. Rice, M. Scheld, B. Spellberg, J. Bartlett, Clin. Infect. Dis. 48 (2009) 1-12.

[2] I. Chopra, C. Schofield, M. Everett, A. O’Neill, K. Miller, M. Wilcox, J.M. Frère, M. Dawson, L. Czaplewski, U. Urleb, P. Courvalin, Lancet Infect. Dis. 8 (2008) 133-139.

[3] W. Vollmer, D. Blanot, M.A. de Pedro, FEMS Microbiol. Rev. 32 (2008) 149-167.

[4] H. Barreteau, A. Kovač, A. Boniface, M. Sova, S. Gobec, D. Blanot, FEMS Microbiol. Rev. 32 (2008) 168-207.

[5] A. Bouhss, S. Dementin, J. van Heijenoort, C. Parquet, D. Blanot, Method. Enzymol. 354 (2002) 189-196.

[6] M. Ikeda, M. Wachi, H.K. Jung, F. Ishino, M. Matsunashi, J. Gen. Appl. Microbiol. 36 (1990) 179-187.

[7] A. Bouhss, D. Mengin-Lecreulx, D. Blanot, J. van Heijenoort, C. Parquet, Biochemistry 36 (1997) 11556-11563.

[8] S.S. Eveland, D.L. Pompliano, M.S. Anderson, Biochemistry 36 (1997) 6223-6229.

[9] A. Bouhss, S. Dementin, C. Parquet, D. Mengin-Lecreulx, J.A. Bertrand, D. Le Beller, O. Dideberg, J. van Heijenoort, D. Blanot, Biochemistry 38 (1999) 12240-12247.

[10] C.A. Smith, J. Mol. Biol. 362 (2006) 640-655.

[11] J.A. Bertrand, G. Auger, L. Martin, E. Fanchon, D. Blanot, D. Le Beller, J. van Heijenoort, O. Dideberg, J. Mol. Biol. 289 (1999) 579-590.

[12] J.A. Bertrand, G. Auger, E. Fanchon, L. Martin, D. Blanot, J. van Heijenoort, O. Dideberg, EMBO J. 16 (1997) 3416-3425.

[13] J.A. Bertrand, E. Fanchon, L. Martin, L. Chantalat, G. Auger, D. Blanot, J. van Heijenoort, O. Dideberg, J. Mol. Biol. 301 (2000) 1257-1266.

[14] Y. Yan, S. Munshi, B. Leiting, M.S. Anderson, J. Chrzas, Z. Chen, J. Mol. Biol. 304 (2000) 435-445.

[15] K.L. Longenecker, G.F. Stamper, P.J. Hajduk, E.H. Fry, C.G. Jakob, J.E. Harlan, R. Edalji, D.M. Bartley, K.A. Walter, L.R. Solomon, T.F. Holzman, Y.G. Gu, C.G. Lerner, B.A. Beutel, V.S. Stoll, Protein Sci. 14 (2005) 3039-3047.

[16] A. Perdih, M. Kotnik, M. Hodošček, T. Šolmajer, Proteins 68 (2007) 243-254.

[17] F. Pratviel-Sosa, F. Acher, F. Trigalo, D. Blanot, R. Azerad, J. van Heijenoort, FEMS Microbiol. Lett. 115 (1994) 223-228.

[18] M.E. Tanner, S. Vaganay, J. van Heijenoort, D. Blanot, J. Org. Chem. 61 (1996) $1756-1760$.

[19] L.D. Gegnas, S.T. Waddell, R.M. Chabin, S. Reddy, K.K. Wong, Bioorg. Med. Chem. Lett. 8 (1998) 1643-1648. 
[20] G. Auger, J. van Heijenoort, D. Blanot, C. Deprun, J. Prakt. Chem. 337 (1995) 351-357.

[21] N.J. Snyder, M.J. Tebbe, F. Victor, L.C. Blaszczak, N.G. Halligan, S. Sigmund, R.C. Thompson, S.C. Wilkie, D.R. Stack, C. Lee, G.B. Birch, C.E. Wu, M.C. Smith, Abstr. Intersci. Conf. Antimicrob. Agents Chemother. 39 (1999) 330

[22] S. Gobec, U. Urleb, G. Auger, D. Blanot, Pharmazie 56 (2001) 295-297.

[23] K. Štrancar, D. Blanot, S. Gobec, Bioorg. Med. Chem. Lett. 16 (2006) 343-348.

[24] F. Victor, M.J. Tebbe, G.B. Birch, M.C. Smith, D.L. Letourneau, C.E. Wu, Abstr. Intersci. Conf. Antimicrob. Agents Chemother. 39 (1999) 330

[25] R. Šink, A. Kovač, T. Tomašić, V. Rupnik, A. Boniface, J. Bostock, I. Chopra, D. Blanot L. Peterlin-Mašič, S. Gobec, A. Zega, Chem. Med. Chem. 3 (2008) 1362-1370.

[26] J.R. Horton, J.M. Bostock, I. Chopra, L. Hesse, S.E.V. Phillips, D.J. Adams, A.P. Johnson, C.W.G. Fishwick, Bioorg. Med. Chem. Lett. 13 (2003) 1557-1560.

[27] C. Paradis-Bleau, M. Beaumont, L. Boudreault, A. Lloyd, F. Sanschagrin, T.D.H. Bugg, R.C. Levesque, Peptides 27 (2006) 1693-1700.

[28] Z. Li, G.D. Francisco, W. Hu, P. Labthavikul, P.J. Petersen, A. Severin, G. Singh, Y. Yang, B.A. Rasmussen, Y.I. Lin, J.S. Skotnicki, T. Mansour, Bioorg. Med. Chem. Lett. 13 (2003) 2591-2594.

[29] S. Antane, C.E. Caufield, W. Hu, D. Keeney, P. Labthavikul, K. Morris, S.M. Naughton, P.J. Petersen, B.A. Rasmussen, G. Singh, Y. Yang, Bioorg. Med. Chem. Lett. 16 (2006) 176-180.

[30] S. Turk, A. Kovač, A. Boniface, J.M. Bostock, I. Chopra, D. Blanot, S. Gobec, Bioorg. Med. Chem. 17 (2009) 1884-1889.

[31] K. Kristan, M. Kotnik, M. Oblak, U. Urleb, J. Biomol. Screen. 14 (2009) 412-418.

[32] M. Kotnik, J. Humljan, C. Contreras-Martel, M. Oblak, K. Kristan, M. Hervé, D. Blanot, U. Urleb, S. Gobec, A. Dessen, T. Šolmajer, J. Mol. Biol. 370 (2007) 107-115.

[33] T. Tomašić, N. Zidar, V. Rupnik, A. Kovač, D. Blanot, S. Gobec, D. Kikelj, L. Peterlin-Maši\&ccaron, Bioorg. Med. Chem. Lett. 19 (2009) 153-157.

[34] J. Humljan, M. Kotnik, C. Contreras-Martel, D. Blanot, U. Urleb, A. Dessen, T. Šolmajer, S. Gobec, J. Med. Chem. 51 (2008) 7486-7494.

[35] M. Simčič, M. Hodošček, J. Humljan, K. Kristan, U. Urleb, D. Kocjan, S. Grdadolnik-Golič, J. Med. Chem. 52 (2009) 2899-2908.
[36] D. Motiejunas, R.C. Wade, Structural, energetic, and dynamic aspects of ligand-receptor interactions. in: D.J. Triggle, J.B. Taylor (Eds.), Comprehensive Medicinal Chemistry II, vol. 4. Elsevier, Oxford, 2007, pp. 193-213.

[37] V. Škarić, B. Djuras, V. Turjak-Zebić, J. Chem. Soc. Perkin Trans. 1 (1975) 1959-1961.

[38] A.F. Abdel-Magid, K.G. Carson, B.D. Harris, C.A. Maryanoff, R.D. Shah, J. Org. Chem. 61 (1996) 3849-3862.

[39] C. Wolf, S. Liu, X. Mei, A.T. August, M.D. Casimir, J. Org. Chem. 71 (2006) 3270-3273.

[40] A. Padwa, M. Dimitroff, A.G. Waterson, T. Wu, J. Org. Chem. 62 (1997) 4088-4096.

[41] A. Perdih, A. Kovač, G. Wolber, D. Blanot, S. Gobec, T. Solmajer, Bioorg. Med. Chem. Lett. 19 (2009) 2668-2673.

[42] P.J. Hajduk, D.D. Augeri, J. Mack, R. Mendoza, J. Yang, S.F. Betz, S.W. Fesik, J. Am. Chem. Soc. 122 (2000) 7898-7904.

[43] G. Auger, L. Martin, J. Bertrand, P. Ferrari, E. Fanchon, S. Vaganay, Y. Pétillot J. van Heijenoort, D. Blanot, O. Dideberg, Protein Expr. Purif. 13 (1998) 23-29.

[44] European Committee for Antimicrobial Susceptibility Testing (EUCAST), Determination of minimum inhibitory concentrations (MICs) of antibacterial agents by broth dilution, Clin. Microbiol. Infect. 9 (2003) 1-7.

[45] Clinical Laboratory Standards Institute (CLSI) M07-A8, Methods for Dilution Antimicrobial Susceptibility Tests for Bacteria that Grow Aerobically; Approved Standard, eighth ed., vol. 29 (2), (2009) pp. 1-65.

[46] L. Kay, P. Keifer, T. Saarinen, J. Am. Chem. Soc. 114 (1992) 10663-10665.

[47] F. Delaglio, S. Grzesiek, G.W. Vuister, G. Zhu, J. Pfeifer, A. Bax, J. Biomol. NMR 6 (1995) 277-293.

[48] T.D. Goddard, D.G. Kneller, SPARKY 3, University of California, San Francisco.

[49] F.H. Schumann, H. Riepl, T. Maurer, W. Gronwald, P. K-Neidig, H.R. Kalbitzer, J. Biomol. NMR 39 (2007) 275-289.

[50] S.E. Cellitti, D.H. Jones, L. Lagpacan, X. Hao, Q. Zhang, H. Hu, S.M. Brittain, A. Brinker, J. Caldwell, B. Bursulaya, G. Spraggon, A. Brock, Y. Ryu, T. Uno, P.G. Schultz, B.H. Geierstanger, J. Am. Chem. Soc. 130 (2008) 9268-9281. 